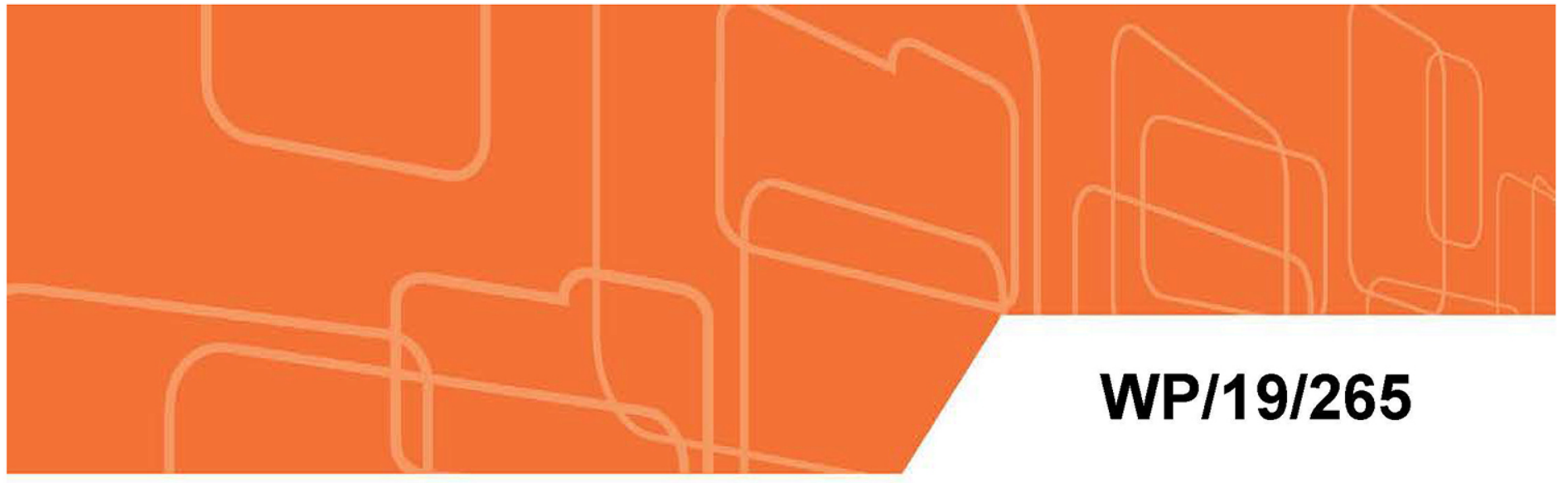

\title{
Bank Capital and the Cost of Equity
}

by Mohamed Belkhir, Sami Ben Naceur, Ralph Chami, and Anis Samet

IMF Working Papers describe research in progress by the author(s) and are published to elicit comments and to encourage debate. The views expressed in IMF Working Papers are those of the author(s) and do not necessarily represent the views of the IMF, its Executive Board, or IMF management. 


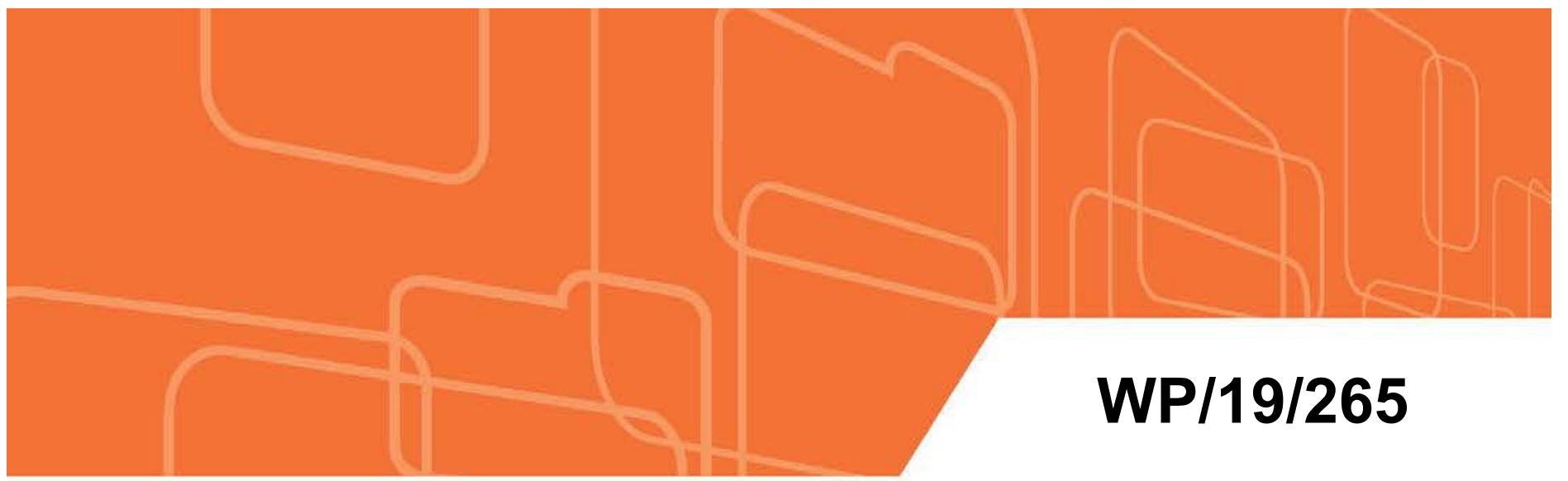

\section{IMF Working Paper}

\section{Bank Capital and the Cost of Equity}

by Mohamed Belkhir, Sami Ben Naceur, Ralph Chami, and Anis Samet

IMF Working Papers describe research in progress by the author(s) and are published to elicit comments and to encourage debate. The views expressed in IMF Working Papers are those of the author(s) and do not necessarily represent the views of the IMF, its Executive Board, or IMF management.

I N T E R N A T I O N A L M O N E T A R Y F U N D 


\title{
IMF Working Paper \\ Institute for Capacity Development
}

Bank Capital and the Cost of Equity

Prepared by Mohamed Belkhir, Sami Ben Naceur, Ralph Chami and Anis Samet ${ }^{1}$

Authorized for distribution by Ralph Chami

December 2019

\section{IMF Working Papers describe research in progress by the author(s) and are published to elicit comments and to encourage debate. The views expressed in IMF Working Papers are those of the author(s) and do not necessarily represent the views of the IMF, its Executive Board, or IMF management.}

\begin{abstract}
Using a sample of publicly listed banks from 62 countries over the 1991-2017 period, we investigate the impact of capital on banks' cost of equity. Consistent with the theoretical prediction that more equity in the capital mix leads to a fall in firms' costs of equity, we find that better capitalized banks enjoy lower equity costs. Our baseline estimations indicate that a 1 percentage point increase in a bank's equity-to-assets ratio lowers its cost of equity by about 18 basis points. Our results also suggest that the form of capital that investors value the most is sheer equity capital; other forms of capital, such as Tier 2 regulatory capital, are less (or not at all) valued by investors. Additionally, our main finding that capital has a negative effect on banks' cost of equity holds in both developed and developing countries. The results of this paper provide the missing evidence in the debate on the effects of higher capital requirements on banks' funding costs.
\end{abstract}

JEL Classification Numbers: G21, G28

Keywords: Cost of equity, Bank capital, Banking regulation, Financial stability

Author's E-Mail Address: mbelkhir@imf.org; sbennaceur@imf.org, rchami@imf.org; asamet@aus.edu

\footnotetext{
${ }^{1}$ We would like to thank Ehsan Ebrahimy (Research Department), Connel Fullenkamp, Thierry Tressel (Monetary and Capital Markets Department) and the Economics seminar participants at the American University of Sharjah for useful comments. Anis Samet gratefully acknowledges the financial support of the Office of Research and Graduate Studies at the American University of Sharjah. Any errors and omissions are, however, the authors' sole responsibility. The views expressed in this paper are those of the author(s) and do not necessarily represent the views of the IMF, its Executive Board, or IMF management.
} 
ABSTRACT _______________________________________________

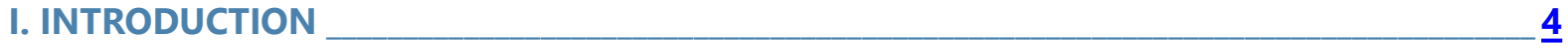

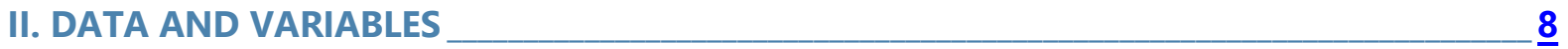

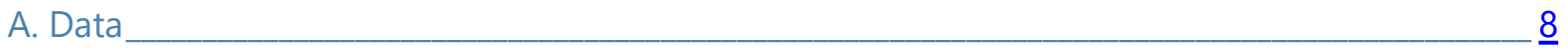

B. The Implied Cost of Equity Capital _______ $\frac{8}{9}$

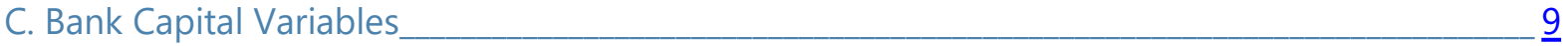

D. Control Variables_______

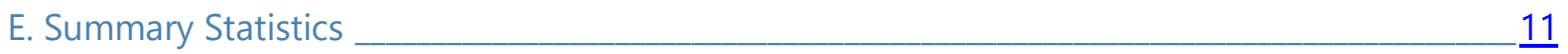

III. EMPIRICAL RESULTS___

A. Graphical Evidence_____ $\frac{16}{19}$

B. Main Evidence___ 19

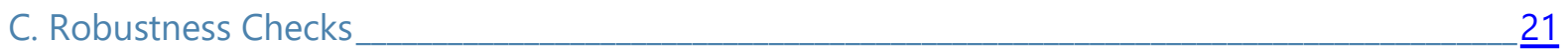

IV. ADDITIONAL ANALYSES____ $\frac{\mathbf{3 1}}{31}$

A. Low vs. High Bank Capitalization_____

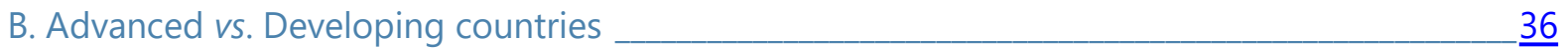

C. Small vs. large banks ________

V. CONCLUSION_______

FIGURES

Bank Cost of Equity and Equity-to-Assets Ratio_________ 15

Cost of Equity (Y-axis) vs. Bank Capital (X-axis) _____ $\frac{17}{18}$

Cost of Equity (Y-axis) vs. EQUITY (X-axis) - selected countries ____ 18

\section{TABLES}

Descriptive Statistics and Correlation Matrix

The Relationship Between Bank Cost of Equity and Capital Measures.____

Robustness Tests Controlling for Additional Variables______

Alternative Measures of the Cost of Equity and Risk Premium ______ 25

Endogeneity and Sample Composition ____

Additional Tests. ____

\section{APPENDICES}

Variables, definitions, and sources

Cost of equity models

\section{REFERENCES}

References 


\section{INTRODUCTION}

The global financial crisis (GFC) provided compelling evidence that capital is a bank's strongest defense against losses from adverse movements in asset values. During the crisis, banks operating with low capital levels were brought to the brink of insolvency as the crisis unfolded and losses accumulated. Many such banks were acquired by healthier ones while others escaped extinction only through government bailouts using public funds. ${ }^{2}$ Policymakers and regulators immediately reacted by stepping up capital requirements, with the aim of strengthening the resilience of individual banks, as well as the whole banking system, to shocks. Efforts to enhance bank capitalization had culminated in the adoption of the Basel III regulatory framework in 2010, which requires banks to hold higher capital ratios compared to those recommended by its predecessor, Basel II. ${ }^{3}$

Yet, eight years after adopting the new, more stringent, capital regulatory framework, bank capital continues to be the subject of a heated debate between numerous banking stakeholders, namely, bankers, regulators, politicians, and academics. In particular, the consequences of increased capital requirements for banks' funding costs continue to be controversial among bankers on the one hand, and regulators and academics on the other. While the latter praise the merits of higher capital ratios on the grounds that they enhance banks' loss-absorption capacities and spare society the heavy costs of bank failures, bankers argue that requiring banks to operate with more equity capital increases funding costs because "equity has a higher cost than debt." To persuade policymakers and society at large, bankers assert that higher funding costs would be passed on to borrowers, which would eventually result in less credit and depress the real economy. For instance, in November

\footnotetext{
${ }^{2}$ Examples of banks bailed out by their competitors include J.P. Morgan's acquisition of Bear Sterns and Washington Mutual; Wells Fargo's $\$ 15.1$ billion acquisition of Wachovia; Bank of America's $\$ 50$ billion rescue package for Merrill Lynch; HBOS $£ 12.2$ billion acquisition by Lloyd's TSB in the U.K; and the acquisition/purchase of Sachsen Landesbank by Baden-Wuerttemberg Landesbank in Germany. Government bank bailouts include the U.S. government's $\$ 700$ billion rescue package (e.g., Citigroup, J.P. Morgan, Bank of America, Morgan Stanley, etc.); the British government’s $£ 500$ billion bank rescue package (e.g., Northern Rock, Royal Bank of Scotland, HBOS and Lloyd's TSB, and Bradford \& Bingley); the German government's €50 billion bailout of Hypo Real Estate; the Swiss government's capital injection into UBS; various European governments' bailouts of Fortis and Dexia; and the Dutch government's $€ 10$ billion capital injection into ING Bank. Banks were also rescued by other investors, such as Warren Buffet's $\$ 5$ billion investment in Goldman Sachs and the Qatar Investment Authority’s capital injection of $£ 1.7$ billion into Barclays.

${ }^{3}$ The Basel III Capital Accord requires banks to have 4.5 percent ratios of common equity to risk-weighted assets at all times (Common Equity Tier 1 ratio: CET1), up from the 2 percent ratio required by Basel II. Additionally, the minimum Tier 1 capital has been increased from Basel II's 4 percent of RWA to 6 percent in Basel III. This 6 percent includes the 4.5 percent CET1 ratio and 1.5 percent of additional Tier 1. Banks must also hold a total capital (Tier 1 plus Tier 2) of at least 8 percent of risk-weighted assets at all times. Basel III also requires that, during good times, banks build additional capital buffers (Common Equity Tier 1) equal to 2.5 percent of their RWAs (Capital Conservation Buffer). Moreover, during periods of excessive credit growth, macroprudential and regulatory authorities can require banks to build additional buffers of Common Equity Tier 1 capital that vary up to 2.5 percent of RWA. Besides the aforementioned capital requirements, Basel III has introduced a new mandatory standard requiring banks to maintain a minimum leverage ratio of 3 percent, calculated as the ratio of Tier 1 capital to total assets.
} 
2016, The Economist reported that European banks were complaining that higher capital requirements "will crimp lending and growth - although research by the BIS suggests that better-capitalized banks have lower funding costs and lend more, not less." 4 On March 7, 2019, the Financial Times reported that "The Federal Reserve has voted against activating a key buffer aimed at guarding against financial stability risks in one of a trio of decisions by U.S regulators that will be greeted with relief by major financial groups."5

The present paper contributes to this debate by empirically examining the impact of capital on banks' costs of equity. We study a large sample of banks from 62 countries over the 1991-2017 period in order to gauge the effects of various bank capital measures on the cost of equity. Our starting point is the theoretical prediction that, as a firm shifts to a capital structure with more equity, its equity cost decreases. As debt decreases in the capital mix, equity becomes less risky, which should lead to a decrease in the risk premium required by equity holders. This, in turn, results in a lower cost of equity capital. From a bank's overall cost of funding perspective and using the Modigliani and Miller (1958) framework (M-M hereafter), we infer that, as a bank increases equity's weight in its capital structure, the equity cost decreases, making less of an impact on its weighted average cost of capital cost (overall funding cost) than would be the case were the cost of equity insensitive to capital structure. If, indeed, the cost of equity was to decrease significantly with the increase in bank equity capital, the impacts of more stringent capital requirements on banks' overall funding costs might not be as severe as bankers claim. Subsequently, any impact from higher capital requirements on the cost of credit would be (extremely) limited. In fact, throughout the paper, our empirical analyses consistently provide evidence of a robust, statistically and economically significant negative relationship between bank capital and the cost of equity. Our baseline regression estimations suggest that a one percentage point increase in the equity-to-assets ratio reduces the cost of equity by about 18 basis points. At very low bank capital levels (first quartile of our sample), the magnitude of the impact of a one percentage point increase in the equity-to-asset ratio on bank cost of equity is even larger (79 basis points).

Many authors have challenged the claim that increased equity requirements are economically costly because they lead to increases in banks' funding costs, which will subsequently be passed on to borrowers. In an open letter to the Financial Times in 2010, twenty prominent academics advocated the imposition of much higher capital requirements than those introduced by Basel III. They argued, "Some claim that requiring more equity lowers the banks' return on equity and increases their overall funding costs. This claim reflects a basic fallacy. Using more equity changes how risk and reward are divided between equity holders and debt holders, but does not by itself affect funding costs. Bankers warn that increased equity requirements would restrict lending and impede growth. These warnings are

\footnotetext{
${ }^{4}$ Article is accessible through the following link: https://www.economist.com/finance-andeconomics/2016/11/24/a-showdown-looms-over-bank-capital-rules.

${ }^{5}$ Emphasis added by the authors. The FT article can be accessed through this link: https://www.ft.com/content/918bc5fc-4054-11e9-b896-fe36ec32aece.
} 
misplaced." ${ }^{\prime 6}$ In a sweeping paper intended to illuminate the debate over capital regulation, Admati et al. (2013, p.1) assert that "the view that equity is expensive is flawed in the context of capital regulation." Part of their argument is based on the premise that greater equity in the capital mix should lower equity risk, leading to decreases in stockholders' required returns, which would not necessarily elevate a bank's overall funding cost. Given what they consider as a trivial cost of capital effect of capital requirements, Admati and Hellwig (2013) suggest that the other benefits of increasing bank capital justify setting the minimum equity-to-assets ratio at between 20 and 30 percent.

Applying the M-M model with taxes, Kashyap et al. (2010) attempt to quantify the impact of increased capital requirements on lending by assessing the cost of capital effect. Their estimations suggest that each 1 percentage point increase in capital raises a bank's weighted average cost of capital by about 2.5 basis points. They conclude that the long-run steady-state impact of increased capital requirements on lending is likely to be modest.

We investigate a scarcely addressed question in the banking empirical literature. Our central contribution is to demonstrate that the theoretical assumption that the required return on equity falls as a bank's financial leverage decreases holds empirically. By doing so, we provide evidence that, in reality, markets do spot and price the change in bank risk ensuing from additional equity in the capital mix. We thus provide a strong basis for using the M-M framework to quantify the effect of capital requirements on banks' costs of funding and, thereby, on their lending costs. Even in the presence of distortions, such as taxes and government deposit and debt guarantees, this framework can still be used to analyze the trade-off between the costs of additional equity (due to such distortions) and benefits (resulting from safer banking systems).

By documenting a negative empirical impact of additional capital on the cost of equity, we provide a missing piece of evidence to the debate on funding cost's effect of higher bank capital requirements. For instance, in defending the view that higher capital requirements come at a price, Elliott (2013) argues that "Modigliani-Miller relies on markets to correctly perceive the change in relative safety that results from adding more equity to the funding mix. However, there is a chance that markets will be too skeptical in this regard, in which case equity and debt costs will not fall as they should, and total funding costs will go up more than would be required by the other factors described above. Higher funding costs would then be passed on to borrowers in whole or part." He adds, "Nonetheless, one can understand why markets may be somewhat skeptical of something on which academics assure them of the truth but have not conclusively proven with empirical evidence." This paper's findings represent a stark response to the skepticism expressed in the above statements about markets' pricing of additional bank equity capital in line with the predictions of standard finance theory.

While strongly advocating higher bank capital requirements, Admati et al. (2013) also question the empirical validity of the assumption that the required return on equity would fall with a rise in equity in the funding mix. They state, "Despite its fundamental importance, empirically establishing this relationship is notoriously difficult" (p.16, footnote 33). Likewise, Kashyap et al. (2010) point to the difficulty of empirically validating the

${ }^{6}$ Adamti et al. (2010): https://www.ft.com/content/63fa6b9e-eb8e-11df-bbb5-00144feab49a. 
assumption that investors demand lower risk premiums for holding better capitalized banks' stocks. They do, however, attempt to provide some supporting evidence by showing that the stock returns of less-levered banks tend to be less volatile and exhibit lower betas. Yet, they stop short of establishing a clear empirical link between these risk measures and equity returns. The work of Baker and Wurgler (2013) comes close to ours in its attempt to validate the bank-capital-cost-of-equity relationship empirically, after admitting that "the validity of the capital structure irrelevance argument is not so clear, and direct empirical evidence is lacking" (p. 2). To emphasize the lack of empirical work addressing the link between bank capital and the cost of equity, they further note that "Admati et al. (2013) cite seven theoretical papers in the relevant section but only one empirical paper, Kashyap, Stein, and Hanson (2010), which does not estimate the cost of equity directly" (p. 2). To estimate leverage's effect on a bank's equity cost, Baker and Wurgler (2013) use a sample of U.S. banks and proceed in two stages. First, they estimate the relationship between the leverage ratio and equity beta, and then estimate the relationship between the equity beta and realized return on equity. Their results point to a positive relationship between financial leverage and equity risk (beta). However, their estimations fail to validate the presence of a positive relationship between beta and stock returns. Rather, their findings reveal that banks with lower betas have higher costs of equity.

Our paper differs from Baker and Wurgler (2013) in various respects. First, while they use realized stock returns as a proxy for the cost of equity, we use an ex-ante measure implied by stock prices and analysts' earnings forecasts (COE hereafter). The recent literature argues that the ex-ante cost of equity implied by stock prices and analysts' earnings forecasts is a better measure of cost of capital than ex post returns (see Bekaert and Harvey, 2000; Hail and Leuz, 2006; Pastor et al., 2008). Pastor et al. (2008) empirically show that the implied cost of capital outperforms realized returns in detecting a risk-return trade-off. They advocate the use of COE rather than realized returns because the former is forward looking, with a better capacity to capture time-varying expected returns. Li et al. (2013) show that COEs are better than traditional ratios at predicting future stock returns.

Additionally, while Baker and Wurgler (2013) focus their analysis on the U.S. banking sector, we take a global perspective and analyze the cost of capital effects of higher capital requirements on an international sample that spans a large number of countries with various levels of economic development and different institutional setups. This global approach is of paramount importance in light of the increasing interconnectedness of national banking systems and the resulting potential vulnerabilities, which may have adverse effects beyond each banking sector's national borders. It is also important to investigate the cost of capital impact of bank capital requirements at the international level, as regulatory capital agreements are intended to be implemented globally. We also exploit our rich dataset to provide insights on the variations in bank capital ratios and cost of equity across countries, geographical regions, levels of economic development, and time periods. Finally, Baker and Wurgler (2013) use a two-step test approach to examine the empirical relationship between leverage and the cost of equity. Instead, we employ a direct empirical specification, where the cost of equity is regressed on the capital ratio and various bank- and country-level controls.

We examine the bank-capital-cost-of-equity relationship in a cross-country setting using bank-level data covering listed banks in 62 countries over the period 1991-2017 (more than 
16,000 bank-year observations). Our estimations indicate that banks with higher capital ratios enjoy a significantly lower cost of equity. We also find that investors value sheer equity capital most, as other forms of capital impact the cost of equity either very slightly (other components of Tier 1 capital) or insignificantly (Tier 2 capital). Our results are robust to a battery of controls for bank- and country-level factors, cost of equity measures, sample composition, and tests that account for potential endogeneity concerns. In additional tests, we find that the magnitude of the impact of capital on bank's cost of equity is larger at banks with lower capital levels. In other words, banks with more binding (lower) capital ratios benefit more, in terms of cost of equity, from additional capital. Our findings also reveal that capital has a stronger effect on banks' cost of equity in developing countries than in advanced countries.

This paper's findings have important policy implications. The documented evidence suggests that the theoretical assumption that equity becomes cheaper as a bank funds itself with more equity capital is, in fact, empirically valid. Considering the scarcity of such empirical evidence, our study may open the door for a more enlightened debate concerning the merits of requiring banks to hold more capital. If, in addition to a decrease in cost of equity, bank cost of debt also declines due to higher capital (as is suggested by theoretical literature and some empirical evidence), the effect of higher capital requirements on the weighted average cost of capital could be far lower than that suggested by bankers. This would be the case even in the presence of distortions, such as taxes and implicit and explicit government guarantees of bank debt. Higher capital requirements can thus come at little or no cost to borrowers, and the benefits in terms of financial stability may outweigh the costs. Hence, the current actions taken by some countries to loosen bank capital regulations may be ill advised and should be reconsidered.

The remainder of this paper is organized as follows. In Section 2, we present our data and define the main variables used in the study. In Section 3, we discuss our empirical results. Section 4 provides additional analyses, and Section 5 concludes the paper.

\section{DATA AND VARIABLES}

\section{A. Data}

To examine the impact of capital on the cost of equity in the banking sector, we begin by extracting all available bank equities listed on all stock exchanges around the world from DataStream for the period 1991-2017. We then merge these data with other data from two other databases: Institutional Brokers Earnings Services (I/B/E/S) from Thomson Reuters, which provides analyst forecast data, and Thomson Reuters and Bloomberg, which provide bank financial statement information. We further extract country variables' data from various databases, including the International Financial Statistics, World Development Indicators, Financial Structure database, etc. The result is a sample of more than 16,000 bank-year observations for 62 countries. Due to data availability, the number of observations varies from one country to another over the sample period. Likewise, the number of observations varies from variable to another.

\section{B. The Implied Cost of Equity Capital}

Following Hail and Leuz (2006) and Dhaliwal et al. (2006), we measure our dependent variable, the implied cost of equity (COE), as the average estimate obtained from four 
different models provided by Claus and Thomas (2001); Gebhardt et al. (2001); Easton (2004); and Ohlson and Juettner-Nauroth (2005). Using the average of four estimates, rather than relying on a single model, reduces the possibility of obtaining biased results (Dhaliwal et al., 2006). The individual estimates of the implied cost of capital we get using the models of Claus and Thomas (2001), Gebhardt et al. (2001), Easton (2004), and Ohlson and JuettnerNauroth (2005) are denoted $r_{C T}, r_{G L S}, r_{E S}, r_{O J N}$ respectively. We note that $r_{O J N}$ is estimated in a closed form solution while $r_{C T}, r_{G L S}$, and $r_{E S}$ involve numerical techniques wherein the solution is bounded between 0 and 100 percent.

To calculate the implied cost of equity, we use the $\mathrm{I} / \mathrm{B} / \mathrm{E} / \mathrm{S}$ database to obtain the positive one-, two-, and three- year-ahead mean forecasted earnings per share $\left(F E P S_{t+j}\right)$, as well as the long-term growth rate forecast. In line with Frankel and Lee (1998) and Hail and Leuz (2009), we substitute the missing or negative $F E P S_{t+j}$ with the historical earnings per share, estimated using the beginning of the year book value per share and the three-year median return on equity in the same year, country, and industry. In this paper, we consider only banks with sufficient I/B/E/S forecasts. We discard bank-year observations for which none of the implied cost of equity estimates converge (Easton, 2004; Claus and Thomas, 2001; and Gebhardt et al., 2001 models), or are undefined (Ohlson and Juettner-Nauroth, 2005 model).

The implied cost of capital is the discount rate $(r)$ that equates the present value of future dividends $(\mathrm{D} t+\tau)$ to the current stock price $(\mathrm{P} t)$ :

$$
P_{t}=\sum_{\tau=1}^{\infty} \frac{D_{t+\tau}}{(1+r)} .
$$

In Appendix B, we provide a brief presentation of the four cost of equity models we rely on in this paper.

\section{Bank Capital Variables}

Our main test variable is bank capital. Throughout the paper, we use three alternative measures of bank capital. Our first measure of capital is a bank's financial leverage, calculated as the ratio of total equity to total assets (EQUITY). It is reasonable to assume that this is the primary measure of capital that equity investors rely on when assessing a bank's financial risk for at least two main reasons. First, it is a simple calculation that reflects the amount of a bank's high-quality capital — with the highest loss-absorption capacity — relative to its total non-risk-weighted exposure. Second, it avoids the drawbacks of risk-weighted capital ratios, which are highly sensitive to risk weights. The latter are, in turn, sensitive to the risk models used and perceived riskiness of assets, and can therefore change from one bank to another, and across countries for the same type of asset. 7 Hence, investors can use this simple leverage ratio to compare the financial risks of banks within a single jurisdiction, as well as across jurisdictions. The second capital measure we use is the Tier 1 regulatory capital ratio, which we obtain by dividing Tier 1 capital by risk-weighted assets (TIER1). Finally, our third measure of capital is the total capital ratio, calculated as the sum of Tier 1

\footnotetext{
7 The global financial crisis has raised questions about the ability of the risk weights used in the Basel regulatory framework to capture banks' actual risks. This has led to controversy over the common practice of relying on low-quality capital, such as Tier 2 capital, due to its limited capacity to absorb losses.
} 
and Tier 2 capital to risk-weighted assets (TOTCAP). Despite their flaws, these two ratios may be followed by equity holders, along the leverage ratio, to assess a bank's financial risk and determine the required rate of return - cost of equity. Tier 1 capital includes common stock and retained earnings, as well as perpetual noncumulative preferred stock. Tier 2 capital is composed of hybrid capital, subordinated debt, revaluation reserves, and loan loss reserves.

\section{Control Variables}

Our regression equations also include a number of bank- and country-level variables intended to capture the potential effects of factors other than capital on banks' cost of equity. In particular, we control for a set of bank-level factors that can shape investors' perceptions of a bank's risk profile, and potentially influence the risk premium they require for investing in the bank's equity. We control for a bank's asset quality using the ratio of loan loss provisions to total loans (PROV). Banks with riskier loan portfolios set up higher provisions to face losses when they materialize. Equity investors may thus require greater compensation from banks with higher provisions (higher risks), which result in a higher cost of equity. We also include a control for a bank's quality of management, measured by the ratio of salaries and benefits to total assets. We label this variable INEFF (for inefficiency). We expect it to be positively associated with the cost of equity, as banks with higher personnel expenses per dollar of assets may be seen by investors as inefficient and penalized with a higher cost of equity. Bank earnings are closely monitored by equity investors and are expected to affect the cost of equity significantly. We thus include the return on assets (ROA) as another control variable in our cost of equity regression equation. We further control for the ratio of deposits to total assets (DEP). The more deposits a bank has, the more stable its funding structure, which would reduce its susceptibility to liquidity problems (e.g., Beltratti and Stulz, 2012; Berger and Bowman, 2013). This can, in turn, lower investors' required return on equity. As a final bank-level control, we include the natural logarithm of total assets (SIZE). Equity investors may perceive larger banks as a source of lower risk due to better asset diversification (e.g., Demsetz and Strahan, 1997) and better monitoring executed by supervisory and regulatory bodies. Additionally, larger banks may be viewed by investors as too big to fail (e.g., Deng et al. 2007; Belkhir, 2013), and the risk premiums they have to pay equity holders may be lower than those required from smaller banks.

Our second set of controls comprises country-level variables. As in prior cross-country equity cost studies (e.g., Hail and Leuz, 2006; Chen et al., 2009; Chen et al., 2011; Belkhir et al., 2019), we include the natural logarithm of GDP per capita (LGDPC), the expected inflation rate (INFL), and the level of a country's stock market development as country-level controls. Per capita GDP is used as a control for a country's income level. The latter reflects various country characteristics, such as institution(al) quality, investor protection, and regulation, which can impact investors' perceptions of bank risk. In particular, investors may be less concerned with banks located in richer countries compared to those in less rich ones. We control for expected inflation because the higher the expected inflation rate and the higher the return on equity required to preserve a constant real rate of return for investors. We use annual realized inflation as a proxy for expected inflation. We also control for a country's stock market development using the ratio of stock market capitalization to GDP (MCAP). Appendix A provides more detailed descriptions of the variables and their sources. 


\section{E. Summary Statistics}

Panel A of Table 1 reports country-by-country median values of COE and our three measures of bank capital. Column 1 of panel A reveals a large cross-country variation in the median cost of equity, with a minimum COE recorded in Australia (9.8 percent) and a maximum observed in Lebanon (25.1 percent). Likewise, columns 2, 3, and 4 show a great deal of cross-country variation in the median values of our three bank capital measures. EQUITY varies between a minimum of 3.1 percent in Belgium and a maximum of 15.7 percent in Serbia. As regards TIER1, the lowest median value is recorded in Italy (7.4 percent), whereas the largest median value is observed in Serbia (18 percent). Italy has the lowest median value of TOTCAP (11.3 percent), while Nigeria has the highest median value of TOTCAP (20.4 percent).

Columns 1 and 2 in panel B of Table 1, and panel A of Figure 1 trace the movement of the median values of COE and our first measure of bank capital (EQUITY) over the sample period for the full sample. They both document COE's tendency to decrease during periods of financial expansion (and stability), and to increase sharply during episodes of financial turmoil. This can be clearly seen in the 1998-2000 period (Russian and LTCM crises) and in the 2008-2010 period (the GFC). Despite these momentary sharp rises in equity cost, overall, there is a cumulative fall in the cost of equity of about 3 percentage points between 1991 and 2017 (from 12.9 percent to 10 percent). By contrast, one can spot a clear upward trend in the ratio of banks' equity to assets (EQUITY). Over our sample period, there is a cumulative 4 percentage point increase in EQUITY, from 6 percent in 1991 to 10 percent in 2017. A closer look at panel A of Figure 1 and the figures reported in column 2 of panel B (Table 1) reveals that an important part of this incremental bank capital has been added since the GFC's breakout; EQUITY has increased from 8.3 percent in 2007-2008 to 10 percent in 2017. If anything, this proves that banks and regulators across the globe have sought to improve bank capitalization in the GFC's aftermath. Columns 3 and 4 of the same table also document substantial increases in the two Basel regulatory capital ratios (TIER1 and TOTCAP) over the 27-year sample, with the gains split (roughly) evenly between the preand post-GFC periods. 
Table 1. Descriptive Statistics and Correlation Matrix Panel A. Medians of the main variables by country

\begin{tabular}{|c|c|c|c|c|c|c|c|c|}
\hline Country & $\begin{array}{c}\text { COE } \\
\text { Median }\end{array}$ & $\underset{\mathbf{N}}{\mathrm{COE}}$ & $\begin{array}{c}\text { EQUITY } \\
\text { Median }\end{array}$ & $\underset{\mathbf{N}}{\text { EQUITY }}$ & $\begin{array}{c}\text { TIER1 } \\
\text { Median }\end{array}$ & $\begin{array}{c}\text { TIER1 } \\
\mathbf{N}\end{array}$ & $\begin{array}{c}\text { TOTCAP } \\
\text { Median }\end{array}$ & $\begin{array}{c}\text { TOTCAP } \\
\mathbf{N}\end{array}$ \\
\hline Argentina & 0.124 & 75 & 0.093 & 75 & . & - & . & - \\
\hline Australia & 0.098 & 261 & 0.061 & 261 & 0.081 & 153 & 0.115 & 153 \\
\hline Austria & 0.114 & 141 & 0.049 & 141 & 0.108 & 83 & 0.156 & 83 \\
\hline Bahrain & 0.108 & 21 & 0.107 & 21 & 0.174 & 17 & 0.186 & 17 \\
\hline Belgium & 0.111 & 127 & 0.031 & 127 & 0.098 & 66 & 0.146 & 61 \\
\hline Brazil & 0.142 & 36 & 0.060 & 36 & 0.159 & 14 & 0.173 & 14 \\
\hline Canada & 0.105 & 270 & 0.051 & 270 & 0.109 & 173 & 0.140 & 168 \\
\hline Chile & 0.113 & 103 & 0.078 & 103 & 0.094 & 54 & 0.133 & 24 \\
\hline China & 0.140 & 181 & 0.061 & 181 & 0.095 & 172 & 0.122 & 164 \\
\hline Colombia & 0.174 & 31 & 0.114 & 31 & 0.088 & 2 & 0.136 & 2 \\
\hline Czech Republic & 0.118 & 19 & 0.075 & 19 & 0.137 & 7 & 0.146 & 7 \\
\hline Denmark & 0.125 & 195 & 0.062 & 195 & 0.098 & 81 & 0.127 & 76 \\
\hline Egypt & 0.156 & 80 & 0.088 & 80 & 0.130 & 47 & 0.143 & 46 \\
\hline Finland & 0.136 & 69 & 0.050 & 69 & 0.082 & 33 & 0.117 & 33 \\
\hline France & 0.116 & 270 & 0.035 & 270 & 0.095 & 89 & 0.130 & 88 \\
\hline Germany & 0.100 & 317 & 0.032 & 317 & 0.089 & 131 & 0.133 & 123 \\
\hline Greece & 0.126 & 329 & 0.063 & 329 & 0.102 & 108 & 0.120 & 92 \\
\hline Hong Kong & 0.134 & 85 & 0.102 & 85 & 0.130 & 28 & 0.180 & 28 \\
\hline Hungary & 0.138 & 45 & 0.105 & 45 & 0.141 & 18 & 0.181 & 18 \\
\hline India & 0.160 & 371 & 0.062 & 371 & 0.096 & 158 & 0.130 & 158 \\
\hline Indonesia & 0.125 & 322 & 0.099 & 322 & 0.153 & 214 & 0.184 & 214 \\
\hline Ireland & 0.106 & 74 & 0.053 & 74 & 0.082 & 43 & 0.122 & 42 \\
\hline Israel & 0.128 & 120 & 0.055 & 120 & 0.080 & 95 & 0.130 & 95 \\
\hline Italy & 0.119 & 692 & 0.062 & 692 & 0.074 & 330 & 0.108 & 327 \\
\hline Japan & 0.104 & 65 & 0.048 & 65 & 0.131 & 21 & 0.156 & 17 \\
\hline Jordan & 0.122 & 24 & 0.129 & 24 & 0.173 & 17 & 0.170 & 15 \\
\hline Kazakhstan & 0.243 & 10 & 0.131 & 10 & 0.162 & 9 & 0.194 & 9 \\
\hline Kenya & 0.178 & 16 & 0.139 & 16 & 0.152 & 14 & 0.165 & 14 \\
\hline Kuwait & 0.112 & 24 & 0.117 & 24 & 0.144 & 13 & 0.155 & 13 \\
\hline Lebanon & 0.251 & 25 & 0.084 & 25 & 0.135 & 22 & 0.141 & 22 \\
\hline Malaysia & 0.101 & 271 & 0.077 & 271 & 0.114 & 155 & 0.148 & 155 \\
\hline Mauritius & 0.123 & 10 & 0.136 & 10 & 0.130 & 7 & 0.149 & 5 \\
\hline Mexico & 0.111 & 50 & 0.106 & 50 & 0.127 & 16 & 0.153 & 15 \\
\hline Morocco & 0.106 & 29 & 0.087 & 29 & . & - & . & - \\
\hline Netherlands & 0.115 & 38 & 0.072 & 38 & 0.133 & 20 & 0.146 & 20 \\
\hline Nigeria & 0.221 & 86 & 0.134 & 86 & 0.174 & 67 & 0.204 & 66 \\
\hline Norway & 0.113 & 333 & 0.068 & 333 & 0.120 & 235 & 0.139 & 224 \\
\hline Oman & 0.126 & 44 & 0.119 & 44 & 0.125 & 43 & 0.152 & 43 \\
\hline Pakistan & 0.154 & 76 & 0.082 & 76 & 0.110 & 45 & 0.150 & 45 \\
\hline Peru & 0.169 & 25 & 0.083 & 25 & . & - & . & - \\
\hline Philippines & 0.111 & 232 & 0.122 & 232 & 0.137 & 106 & 0.166 & 106 \\
\hline Poland & 0.105 & 184 & 0.108 & 184 & 0.142 & 71 & 0.150 & 64 \\
\hline Portugal & 0.116 & 155 & 0.045 & 155 & 0.086 & 73 & 0.113 & 67 \\
\hline Qatar & 0.120 & 52 & 0.130 & 52 & 0.157 & 51 & 0.163 & 43 \\
\hline Russian Federation & 0.201 & 39 & 0.101 & 39 & 0.104 & 34 & 0.139 & 34 \\
\hline Saudi Arabia & 0.112 & 105 & 0.137 & 105 & 0.151 & 104 & 0.173 & 104 \\
\hline Serbia & 0.242 & 5 & 0.157 & 5 & 0.180 & 3 & 0.187 & 3 \\
\hline Singapore & 0.102 & 141 & 0.095 & 141 & 0.132 & 116 & 0.170 & 116 \\
\hline South Africa & 0.133 & 151 & 0.066 & 151 & 0.126 & 80 & 0.148 & 77 \\
\hline South Korea & 0.136 & 97 & 0.064 & 97 & 0.104 & 20 & 0.131 & 19 \\
\hline Spain & 0.113 & 397 & 0.060 & 397 & 0.088 & 180 & 0.125 & 176 \\
\hline Sri Lanka & 0.156 & 74 & 0.091 & 74 & 0.123 & 36 & 0.142 & 35 \\
\hline Sweden & 0.104 & 178 & 0.042 & 178 & 0.076 & 101 & 0.114 & 101 \\
\hline Switzerland & 0.100 & 382 & 0.070 & 382 & 0.163 & 214 & 0.187 & 116 \\
\hline Thailand & 0.126 & 219 & 0.087 & 219 & 0.111 & 155 & 0.151 & 155 \\
\hline Tunisia & 0.114 & 39 & 0.081 & 39 & & - & . & - \\
\hline Turkey & 0.153 & 213 & 0.112 & 213 & 0.152 & 87 & 0.178 & 87 \\
\hline Ukraine & 0.231 & 8 & 0.131 & 8 & 0.134 & 5 & 0.208 & 5 \\
\hline United Arab Emirates & 0.133 & 110 & 0.118 & 110 & 0.160 & 105 & 0.188 & 104 \\
\hline United Kingdom & 0.117 & 239 & 0.045 & 239 & 0.086 & 180 & 0.144 & 180 \\
\hline United States & 0.100 & 8,370 & 0.092 & 8,370 & 0.122 & 4,477 & 0.137 & 4,466 \\
\hline Vietnam & 0.106 & 26 & 0.077 & 26 & . & - & . & - \\
\hline Total & 0.108 & 16,776 & 0.083 & 16,776 & 0.118 & 8,998 & 0.139 & 8,754 \\
\hline
\end{tabular}

This table reports descriptive statistics and Pearson's correlation coefficients for the variables used in the main regressions. Panel A reports the medians (Median) and the number of observations $(N)$ by country of the main variables used in our regressions. Panel B reports the medians (Median) and the number of observations $(N)$ by year of the main variables used in our regressions. Panel $\mathrm{C}$ reports descriptive statistics for all the explanatory variables. In Panel C, the labels Mean, P25, P50, P75, STD, and $N$ stand for the mean, the $25^{\text {th }}$ percentile, the median, the $75^{\text {th }}$ percentile, the standard deviation, and the number of observations. Panel D reports Pearson's correlation coefficients for the main variables. In Panel D, correlation coefficients in bold are significant at the $1 \%$ level. The total sample consists of 16,776 observations from 62 countries between 1991 and 2017. Appendix A provides definitions and data sources for all the variables 


\begin{tabular}{|c|c|c|c|c|c|c|c|c|c|}
\hline \multirow[b]{2}{*}{ Year } & \multicolumn{8}{|c|}{$\begin{array}{l}\text { Table 1. Descriptive Statistics and Correlation Matrix (Continued) } \\
\text { Panel B. Median values of COE, EQUITY, TIER1 and TOTCAP by year. }\end{array}$} & \multirow[b]{2}{*}{$\begin{array}{l}\text { COE } \\
\text { (Developing) } \\
\quad \text { Median }\end{array}$} \\
\hline & $\begin{array}{l}\text { COE } \\
\text { Median }\end{array}$ & $\begin{array}{c}\text { COE } \\
\text { N }\end{array}$ & $\begin{array}{l}\text { EQUITY } \\
\text { Median }\end{array}$ & $\begin{array}{l}\text { EQUITY } \\
\mathbf{N}\end{array}$ & $\begin{array}{l}\text { TIER1 } \\
\text { Median }\end{array}$ & $\begin{array}{l}\text { TIER1 } \\
\mathbf{N}\end{array}$ & $\begin{array}{l}\text { TOTCAP } \\
\text { Median }\end{array}$ & $\begin{array}{l}\text { TOTCAP } \\
\mathbf{N}\end{array}$ & \\
\hline 1991 & 0.129 & 239 & 0.060 & 239 & e & - & . & - & 0.115 \\
\hline 1992 & 0.124 & 293 & 0.062 & 293 & 0.058 & 1 & 0.090 & 1 & 0.116 \\
\hline 1993 & 0.122 & 365 & 0.069 & 365 & 0.059 & 6 & 0.099 & 6 & 0.126 \\
\hline 1994 & 0.12 & 408 & 0.072 & 408 & 0.079 & 7 & 0.129 & 7 & 0.125 \\
\hline 1995 & 0.121 & 495 & 0.072 & 495 & 0.081 & 8 & 0.131 & 8 & 0.140 \\
\hline 1996 & 0.115 & 559 & 0.077 & 559 & 0.083 & 10 & 0.127 & 9 & 0.132 \\
\hline 1997 & 0.107 & 644 & 0.077 & 644 & 0.078 & 11 & 0.131 & 11 & 0.125 \\
\hline 1998 & 0.084 & 711 & 0.079 & 711 & 0.073 & 16 & 0.127 & 16 & 0.131 \\
\hline 1999 & 0.099 & 748 & 0.082 & 748 & 0.074 & 19 & 0.126 & 19 & 0.135 \\
\hline 2000 & 0.117 & 671 & 0.077 & 671 & 0.078 & 46 & 0.116 & 44 & 0.143 \\
\hline 2001 & 0.108 & 676 & 0.079 & 676 & 0.082 & 119 & 0.120 & 113 & 0.159 \\
\hline 2002 & 0.102 & 666 & 0.080 & 666 & 0.087 & 131 & 0.125 & 124 & 0.139 \\
\hline 2003 & 0.102 & 641 & 0.080 & 641 & 0.091 & 226 & 0.125 & 218 & 0.139 \\
\hline 2004 & 0.103 & 651 & 0.077 & 651 & 0.103 & 413 & 0.131 & 395 & 0.139 \\
\hline 2005 & 0.097 & 676 & 0.080 & 676 & 0.107 & 559 & 0.126 & 539 & 0.121 \\
\hline 2006 & 0.097 & 734 & 0.080 & 734 & 0.105 & 630 & 0.124 & 614 & 0.121 \\
\hline 2007 & 0.098 & 718 & 0.083 & 718 & 0.104 & 610 & 0.123 & 595 & 0.115 \\
\hline 2008 & 0.114 & 697 & 0.083 & 697 & 0.1 & 599 & 0.120 & 585 & 0.120 \\
\hline 2009 & 0.129 & 688 & 0.086 & 688 & 0.109 & 603 & 0.130 & 589 & 0.126 \\
\hline 2010 & 0.129 & 731 & 0.088 & 731 & 0.121 & 644 & 0.143 & 629 & 0.133 \\
\hline 2011 & 0.123 & 699 & 0.093 & 699 & 0.129 & 628 & 0.150 & 611 & 0.129 \\
\hline 2012 & 0.117 & 689 & 0.092 & 689 & 0.13 & 619 & 0.154 & 602 & 0.142 \\
\hline 2013 & 0.108 & 647 & 0.096 & 647 & 0.134 & 583 & 0.156 & 565 & 0.130 \\
\hline 2014 & 0.112 & 676 & 0.096 & 676 & 0.132 & 607 & 0.151 & 594 & 0.129 \\
\hline 2015 & 0.105 & 680 & 0.100 & 680 & 0.13 & 622 & 0.149 & 610 & 0.123 \\
\hline 2016 & 0.106 & 703 & 0.099 & 703 & 0.128 & 654 & 0.147 & 637 & 0.131 \\
\hline 2017 & 0.100 & 671 & 0.100 & 671 & 0.129 & 627 & 0.150 & 613 & 0.121 \\
\hline Total & 0.108 & 16,776 & 0.083 & 16,776 & 0.118 & 8,998 & 0.139 & 8,754 & 0.128 \\
\hline
\end{tabular}


Table 1. Descriptive Statistics and Correlation Matrix (Continued)

Panel C. Full sample summary statistics of the main variables used in the regression analysis.

\begin{tabular}{lcccccc} 
Variable & Mean & P25 & P50 & P75 & STD & N \\
\hline COE & 0.121 & 0.091 & 0.108 & 0.134 & 0.058 & 16,776 \\
EQUITY & 0.087 & 0.062 & 0.083 & 0.104 & 0.039 & 16,776 \\
TIER1 & 0.130 & 0.098 & 0.118 & 0.142 & 0.078 & 8,998 \\
TOTCAP & 0.153 & 0.121 & 0.139 & 0.164 & 0.077 & 8,754 \\
SIZE & 2.246 & 0.638 & 1.979 & 3.688 & 2.051 & 16,776 \\
PROV & 0.764 & 0.190 & 0.440 & 0.960 & 1.028 & 16,776 \\
INEFF & 0.013 & 0.009 & 0.013 & 0.016 & 0.006 & 16,776 \\
ROA & 0.010 & 0.005 & 0.011 & 0.013 & 0.029 & 16,776 \\
DEP & 0.668 & 0.570 & 0.713 & 0.800 & 0.173 & 16,776 \\
LNGDPC & 10.054 & 9.970 & 10.403 & 10.746 & 1.046 & 16,776 \\
INFL & 0.032 & 0.016 & 0.027 & 0.034 & 0.034 & 16,776 \\
MCAP & 0.955 & 0.570 & 1.070 & 1.306 & 0.493 & 16,776
\end{tabular}

Table 1. Descriptive Statistics and Correlation Matrix (Concluded)

Panel D. Correlation matrix

\begin{tabular}{lccccccccc|} 
& COE & EQUITY & TOTCAP & TIER1 & SIZE & PROV & INEFF & ROA & DEP \\
\hline COE & 1.000 & & & & & & & & \\
EQUITY & $\mathbf{- 0 . 0 9 0}$ & $\mathbf{1 . 0 0 0}$ & & & & & & & \\
TOTCAP & $\mathbf{- 0 . 0 6 2}$ & $\mathbf{0 . 3 0 6}$ & $\mathbf{1 . 0 0 0}$ & & & & & & \\
TIER1 & $\mathbf{- 0 . 0 8 1}$ & $\mathbf{0 . 3 8 0}$ & $\mathbf{0 . 9 6 8}$ & 1.000 & & & & & \\
SIZE & $\mathbf{0 . 0 6 6}$ & $\mathbf{- 0 . 3 8 9}$ & $\mathbf{- 0 . 1 1 0}$ & $\mathbf{- 0 . 2 0 5}$ & 1.000 & & & & \\
PROV & $\mathbf{0 . 3 7 8}$ & $\mathbf{0 . 0 3 2}$ & -0.008 & $\mathbf{- 0 . 0 3 4}$ & $\mathbf{0 . 0 8 7}$ & 1.000 & & & \\
INEFF & $\mathbf{0 . 0 4 4}$ & $\mathbf{0 . 2 1 0}$ & $\mathbf{0 . 0 3 7}$ & $\mathbf{0 . 0 7 1}$ & $\mathbf{- 0 . 3 1 4}$ & $\mathbf{0 . 1 3 6}$ & 1.000 & & \\
ROA & $\mathbf{- 0 . 1 4 2}$ & $\mathbf{0 . 3 4 3}$ & $\mathbf{0 . 1 3 2}$ & $\mathbf{0 . 1 3 4}$ & $\mathbf{- 0 . 0 9 8}$ & $\mathbf{- 0 . 2 9 2}$ & $\mathbf{0 . 1 4 7}$ & 1.000 & \\
DEP & $\mathbf{- 0 . 0 5 6}$ & $\mathbf{0 . 1 9 7}$ & 0.015 & $\mathbf{0 . 0 7 6}$ & $\mathbf{- 0 . 4 8 5}$ & $\mathbf{- 0 . 0 5 0}$ & $\mathbf{0 . 2 6 3}$ & $\mathbf{0 . 0 7 6}$ & 1.000 \\
LNGDPC & $\mathbf{- 0 . 2 4 2}$ & $\mathbf{- 0 . 0 2 2}$ & $\mathbf{- 0 . 0 4 0}$ & 0.021 & $\mathbf{- 0 . 0 5 2}$ & $\mathbf{- 0 . 2 6 5}$ & $\mathbf{- 0 . 0 4 1}$ & $\mathbf{- 0 . 2 1 4}$ & $\mathbf{- 0 . 0 6 1}$ \\
INFL & $\mathbf{0 . 3 0 6}$ & $\mathbf{0 . 0 9 5}$ & $\mathbf{0 . 0 3 8}$ & 0.008 & $\mathbf{- 0 . 0 5 4}$ & $\mathbf{0 . 1 6 7}$ & $\mathbf{0 . 1 9 9}$ & $\mathbf{0 . 2 8 4}$ & 0.015 \\
MCAP & $\mathbf{- 0 . 2 8 3}$ & $\mathbf{0 . 1 3 7}$ & $\mathbf{0 . 0 4 3}$ & $\mathbf{0 . 1 0 5}$ & $\mathbf{- 0 . 1 8 9}$ & $\mathbf{- 0 . 2 9 0}$ & -0.011 & 0.011 & $\mathbf{0 . 2 6 9}$ \\
& & & & & & & & & \\
\hline
\end{tabular}

CInternational Monetary Fund. Not for Redistribution 
Panel B of Table 1 shows the median cost of equity and the median equity-to-assets ratio by year, across two subsamples (advanced economies and developing countries). Panel B of Figure 1 records the movement(s) of these two medians across the two country groups over time. Overall, we note a persistent gap of about 3 percentage points between the median bank cost of equity for developing countries and the one for advanced economies. Except during the GFC's peak (2008-2009), banks in advanced countries enjoy a lower cost of equity compared to those in developing countries. Interestingly, bank capitalization seems to follow the same path over the years across developing and advanced countries, and the typical bank seems to operate at the same capital ratio level, whether located in a developed or developing country. Global factors, especially international capital regulation, may be thought of as the main driving forces behind this common path of bank capitalization.

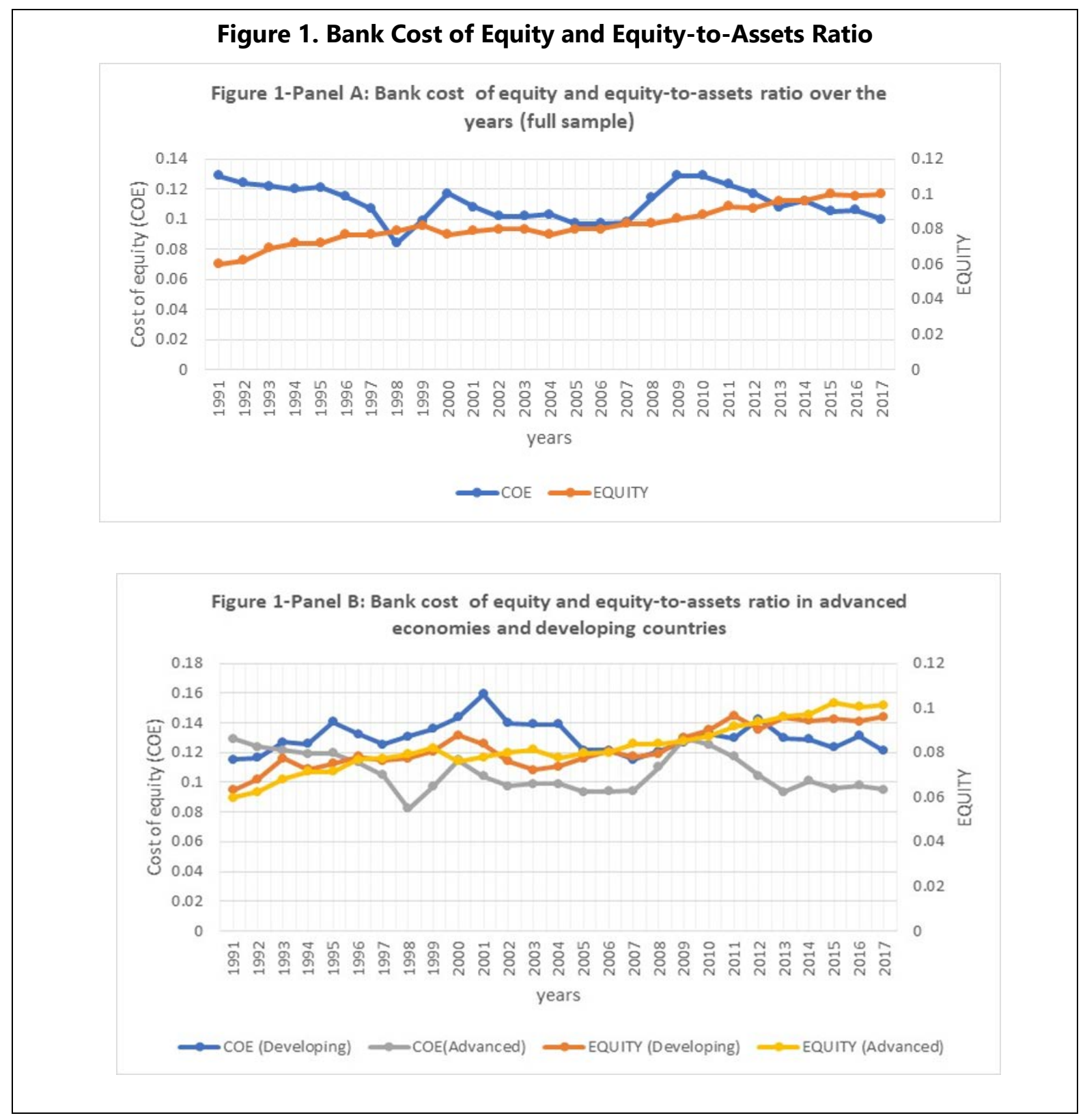


Panel $\mathrm{C}$ of Table 1 presents the sample descriptive statistics for all of the variables used in our analysis of the bank-capital-cost of equity relationship. A sample bank has a mean $\mathrm{COE}$ of 12.1 percent (median: 10.8 percent), and a mean financial leverage ratio (EQUITY) of 8.7 percent (median: 8.3 percent). The average bank has a logarithm of total assets equal to 2.246 (median: 1.979), a ratio of loan loss provisions to loans of 76.4 percent (median: 44 percent), a ratio of salaries and benefits to assets of 1.3 percent (median: 1.3 percent), a return on assets of 1.0 percent (median 1.1 percent), and a ratio of deposits to assets of 66.8 percent (median: 71.3 percent). Further, the different variables' standard deviations in the table suggest that the banks in our sample have different characteristics in terms of capitalization, size, asset quality, profitability, liquidity, etc. The standard deviations of our country-level variables also suggest that our sample banks come from countries with varying levels of income, inflation, and financial development. As previously indicated, the number of observations varies from one variable to another due to missing observations for some variables.

In panel D of Table 1, we report the Pearson correlation coefficients among the different variables we use in our main analysis. Consistent with (the) finance theory predictions, COE is negatively and significantly correlated (at the 99 percent level) with our three measures of bank capital, with the highest correlation coefficient observed for EQUITY (-0.09). Additionally, most of the control variables are correlated with COE in line with theoretical predictions and the findings of prior empirical literature. Importantly, the control variables generally exhibit low correlations, reassuring us that multicollinearity is not a major challenge to our empirical analyses.

\section{EMPIRICAL RESULTS}

\section{A. Graphical Evidence}

Our primary conjecture is that banks operating with more equity capital in their capital mix bear a lower cost of equity capital. As a preamble to our multivariate analysis of the bankcapital-cost of equity relationship, in this section, we present scatterplots that display the relationship between $\mathrm{COE}$ and our measures of bank capital. In panel A of Figure 2, we use the full sample and report a clear negative association between the cost of equity (on the Yaxis) and EQUITY (on the X-axis). This negative relationship holds when we use TIER1 (panel B) and TOTCAP (panel C) as measures of bank capital. In the remainder of Figure 2 (panels D, E, F, G, H, and I), we provide scatterplots illustrating the bank capital-cost of equity relationships for selected advanced economy countries (Germany, U.K, and U.S) and developing countries (India, Malaysia, and Thailand). These graphs point to the presence of a negative association between the cost of equity and bank capital in each of the selected countries. This observation holds for most of the countries in our sample. Hence, graphic evidence suggests that bank capital and the cost of equity are negatively associated. We now turn to multivariate regression techniques to investigate the precise link between capital and the cost of equity. 
Figure 2: Cost of Equity (Y-axis) vs. Bank Capital (X-axis)

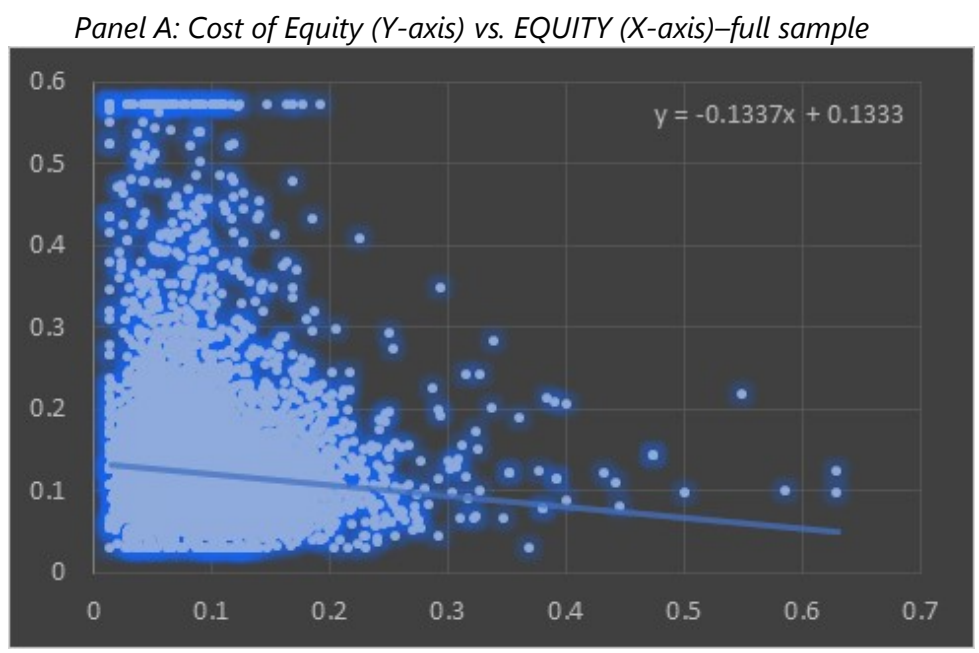

Panel B: Cost of Equity (Y-axis) vs. TIER1 (X-axis)-full sample

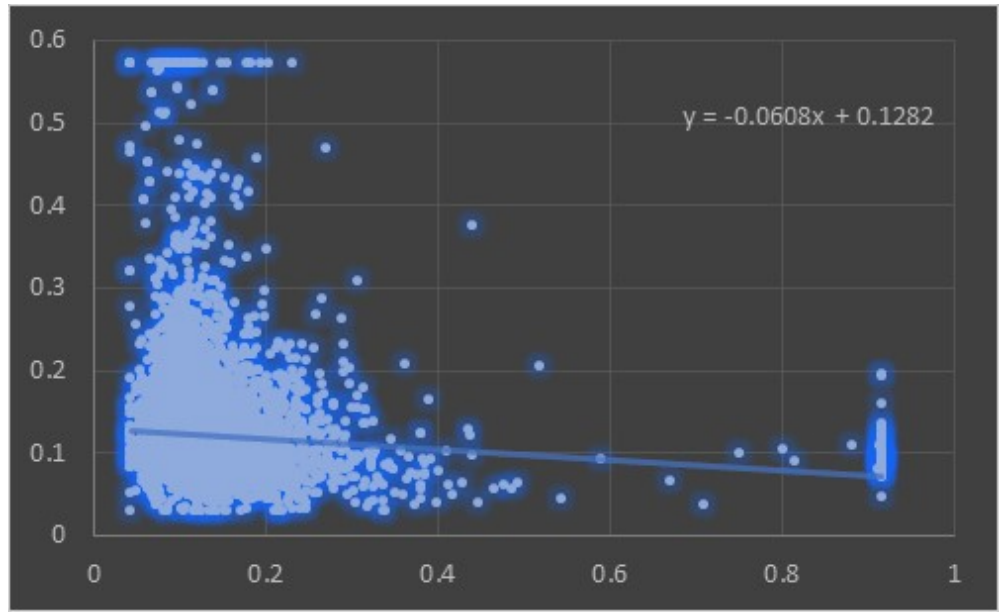

Panel C: Cost of Equity (Y-axis) vs. TOTCAP (X-axis) - full sample

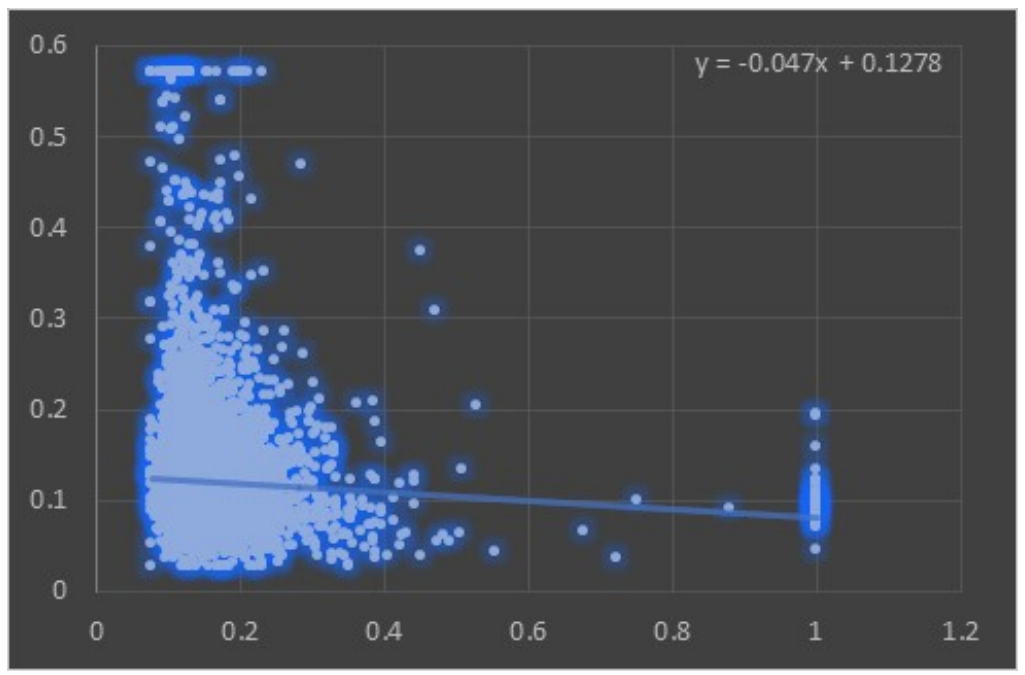




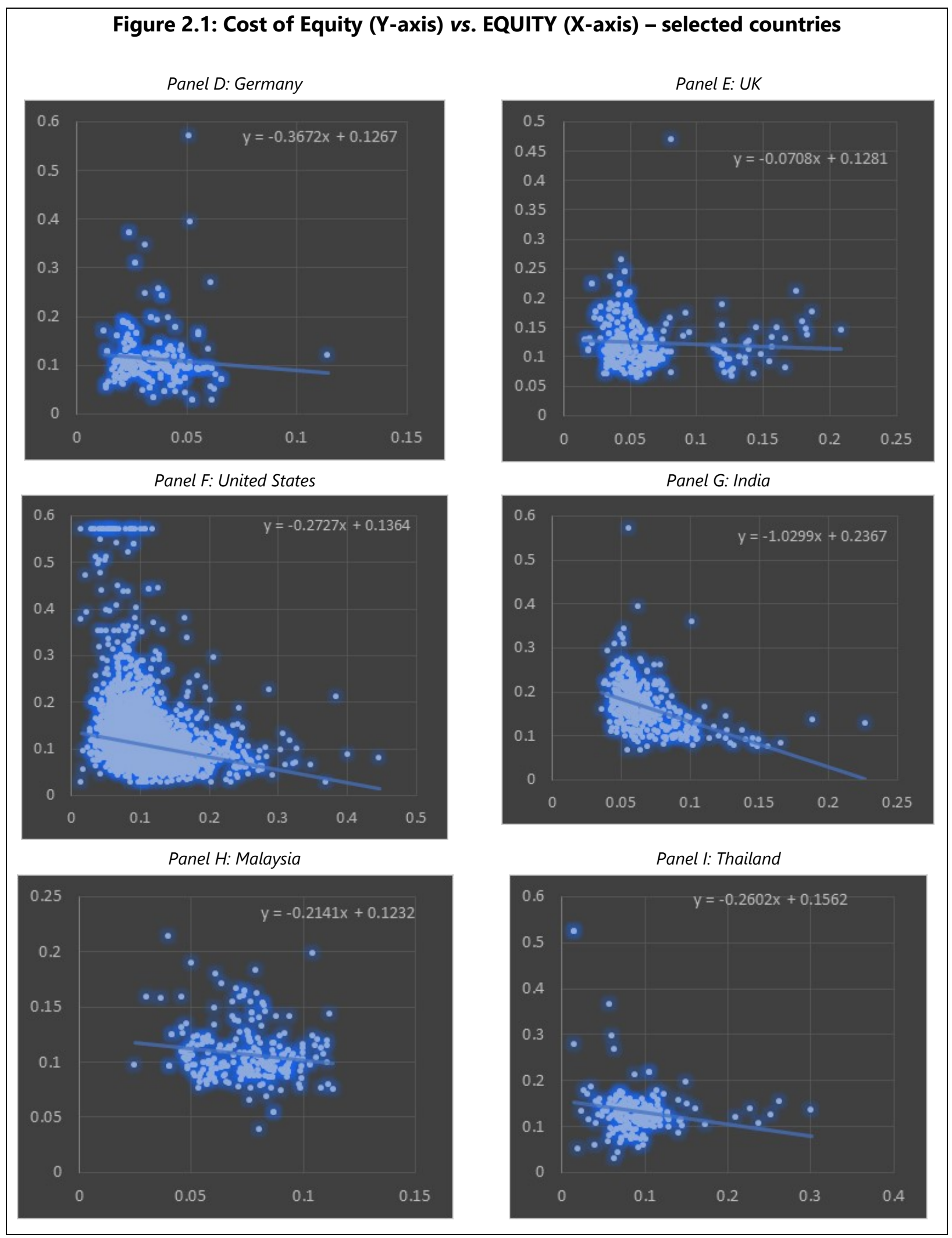

CInternational Monetary Fund. Not for Redistribution 


\section{B. Main Evidence}

In this section, we investigate bank capital's impact on the cost of equity using a multivariate regression analysis. To this end, we estimate various specifications of the regression model below. Specifically, we regress COE on a measure of bank capital (CAPITAL: EQUITY, TIER1, or TOTCAP) and a set of firm- and country-level control variables (CONTROLS):

$$
\operatorname{COE}_{t}=\alpha_{0}+\beta_{1} \operatorname{CAPITAL}_{t-1}+\beta_{2} \operatorname{CONTROLS}_{t-1}+F E+\varepsilon_{t}
$$

In the above model, $\varepsilon_{t}$ represents an error term and $F E$ represents a set of country and year fixed effects. Due to the nature of our sample, which includes banks from many countries, the country and year fixed effects are intended to control for any country- and time-specific factors that may affect banks' cost of equity or the potential association between bank capital and the cost of equity. As indicated in Demirguc-Kunt et al. (2013), such factors may include differences in interest rates and other macroeconomic variables, cross-country disparities relating to the severity of the financial crisis and its economic repercussions, authorities' different policy responses, variations in the quality of bank regulation and supervision, and differences in accounting and regulatory standards. By including country and year fixed effects we reduce the potential bias caused by omitted variables.

Table 2 presents our main evidence of the bank capital-cost of equity relationship. Columns (1)-(3) report the results of our estimations using EQUITY as a measure of bank capital. Column 1, which includes only bank-level controls, shows that, consistent with our expectations, EQUITY is negative and statistically significant at the 1 percent level. This suggests that banks with higher ratios of equity capital to assets bear lower costs of equity. This evidence is in favor of the theoretical prediction that an increase in equity capital reduces a bank's financial risk and eventually leads investors to require lower equity returns. This, in turn, translates into lower costs of equity. The impact of EQUITY is not only statistically significant, but also economically meaningful. The coefficient estimate for EQUITY in column (1) suggests that a one standard deviation increase in EQUITY (0.039) leads to a 72-basis-point drop in the cost of equity $\left(-0.186^{*} 0.039=-0.0072\right)$, all else being equal. Similarly, a 10-percentage-point increase in EQUITY would reduce the cost of equity by a significant 1.86 percentage points. In columns (2)-(3), we gradually augment the COE regression model with country-level variables. In column (2), we add the natural logarithm of GDP per capita and the inflation rate. In column (3), we further add a measure of stock market development, namely, stock market capitalization to GDP. Adding any of these variables alters neither the statistical nor the economic significance of our main variable of interest, EQUITY. The latter continues to load negative and statistically significant at the 1 percent level, with roughly the same economic magnitude.

Across the three models reported in columns (1)-(3) of Table 2, the coefficient estimates for our bank- and country-level control variables are generally consistent with our predictions and the prior literature. In particular, the positive, significant coefficient estimate for PROV suggests that the cost of equity increases as the quality of a bank's loan portfolio deteriorates. The negative and significant coefficient estimate on ROA indicates that more profitable banks enjoy a lower cost of equity. Likewise, banks with a lower liquidity risk (higher DEP) face a lower cost of equity. In addition, the coefficient estimate for SIZE is consistently 
negative and significant across all three COE models, implying that larger banks enjoy a lower cost of equity, all else being equal. Our estimations also reveal that banks' cost of equity depends on their home countries' income levels; as suggested by the negative and significant coefficient for LGDPC, banks located in richer countries enjoy a lower cost of equity. As expected, a rise in expected inflation is conducive to a higher bank cost of equity. Additionally, stock market development contributes to the lowering of banks' cost of equity; the coefficient estimate on MCAP is negative and significant at the 1 percent level.

In columns (4)-(9) of Table 2, we replicate the analyses reported in columns (1)-(3) using TIER1 and TOTCAP as alternative measures of bank capital. The findings suggest that using the ratio of Tier 1 capital to risk-weighted assets as an alternative bank capital measure substantiates our initial finding on the influence of bank capital on the cost of equity. Specifically, our estimates reveal a negative association between the ratio of Tier 1 capital to risk-weighted assets and the cost of equity. The coefficient estimate for TIER1 is consistently negative and significant at the 1 percent level across columns (4)-(6). The economic significance of TIER1's coefficient estimate is, however, smaller than EQUITY's. Using the estimated coefficient on TIER1 in column (4), a one standard deviation increases in TIER1 (0.078) translates into a mere 26 -basis-point drop in the cost of equity $(-0.034 * 0.078=-$ 0.0026). This is a reasonable finding given that the additional forms of capital that enter the composition of Tier 1 capital (besides equity capital) have lower loss-absorption capacities and are therefore not valued by equity investors as they value pure equity capital.

The results reported in columns (7)-(9) are qualitatively similar to those reported in columns (4)-(6). The coefficient estimate on TOTCAP is negative and significant at the 1 percent level and has the same magnitude as the coefficient on TIER1. This result suggests that the additional capital entering the composition of bank total capital on top of Tier 1 capital (i.e., Tier 2 capital) is not priced by stockholders. Indeed, our results imply that investors perceive Tier 2 capital as having no effect on their financial risk. Overall, the results reported in Table 2 suggest that investors do not value Tier 2 capital, and their perceived financial risk is only affected by sheer equity and, to a lesser extent, by the other components of Tier 1 capital. To validate this inference, we re-estimate the cost of equity model using the ratio of Tier 2 to risk-weighted assets as a measure of bank capital. Our results (unreported) confirm that Tier 2 capital is not a factor that determines banks' cost of equity; the coefficient estimate on Tier 2 capital is statistically insignificant at the conventional level.

In sum, our estimations indicate that a bank's cost of equity declines with the amount of equity capital with which it operates. In other words, as predicted by financial theory, equity capital lowers a bank stockholder's financial risk, which eventually leads to a lower cost of equity. This result holds, even when we control for various bank- and country-level factors that may affect banks' cost of equity. 


\begin{tabular}{|c|c|c|c|c|c|c|c|c|c|}
\hline & (1) & (2) & (3) & (4) & (5) & (6) & (7) & (8) & (9) \\
\hline VARIABLES & COE & $C O E$ & $C O E$ & COE & $C O E$ & $C O E$ & $C O E$ & COE & $C O E$ \\
\hline EQUITY & $\begin{array}{c}-0.186 * * * \\
(-9.670)\end{array}$ & $\begin{array}{c}-0.186 * * * \\
(-10.085)\end{array}$ & $\begin{array}{c}-0.175 * * * \\
(-9.517)\end{array}$ & & & & & & \\
\hline TIER1 & & & & $\begin{array}{c}-0.034 * * * \\
(-5.302)\end{array}$ & $\begin{array}{c}-0.035 * * * \\
(-5.228)\end{array}$ & $\begin{array}{c}-0.027 * * * \\
(-4.091)\end{array}$ & & & \\
\hline TOTCAP & & & & & & & $\begin{array}{c}-0.034 * * * \\
(-5.103)\end{array}$ & $\begin{array}{c}-0.035^{* * *} \\
(-5.102)\end{array}$ & $\begin{array}{c}-0.029 * * * \\
(-4.337)\end{array}$ \\
\hline PROV & $\begin{array}{c}0.015^{* * *} \\
(12.246)\end{array}$ & $\begin{array}{l}0.015^{* * *} \\
(13.929)\end{array}$ & $\begin{array}{c}0.015^{* * *} \\
(13.438)\end{array}$ & $\begin{array}{c}0.016^{* * *} \\
(9.321)\end{array}$ & $\begin{array}{c}0.016^{* * *} \\
(10.130)\end{array}$ & $\begin{array}{c}0.015^{* * *} \\
(9.626)\end{array}$ & $\begin{array}{c}0.015^{* * *} \\
(8.922)\end{array}$ & $\begin{array}{c}0.015^{* * *} \\
(9.705)\end{array}$ & $\begin{array}{c}0.015^{* * *} \\
(9.220)\end{array}$ \\
\hline INEFF & $\begin{array}{l}0.196^{*} \\
(1.896)\end{array}$ & $\begin{array}{c}-0.097 \\
(-1.033)\end{array}$ & $\begin{array}{c}-0.136 \\
(-1.458)\end{array}$ & $\begin{array}{l}-0.241^{*} \\
(-1.716)\end{array}$ & $\begin{array}{c}-0.198 \\
(-1.565)\end{array}$ & $\begin{array}{c}-0.138 \\
(-1.098)\end{array}$ & $\begin{array}{l}-0.250^{*} \\
(-1.703)\end{array}$ & $\begin{array}{c}-0.179 \\
(-1.359)\end{array}$ & $\begin{array}{c}-0.113 \\
(-0.867)\end{array}$ \\
\hline ROA & $\begin{array}{c}-0.517 * * * \\
(-4.267)\end{array}$ & $\begin{array}{c}-0.544 * * * \\
(-4.826)\end{array}$ & $\begin{array}{c}-0.541 * * * \\
(-4.827)\end{array}$ & $\begin{array}{c}-0.822 * * * \\
(-5.084)\end{array}$ & $\begin{array}{c}-0.891 * * * \\
(-6.177)\end{array}$ & $\begin{array}{c}-0.896 * * * \\
(-6.247)\end{array}$ & $\begin{array}{c}-0.857 * * * \\
(-5.000)\end{array}$ & $\begin{array}{c}-0.939 * * * \\
(-6.158)\end{array}$ & $\begin{array}{c}-0.941 * * * \\
(-6.207)\end{array}$ \\
\hline DEP & $\begin{array}{c}-0.022 * * * \\
(-4.374)\end{array}$ & $\begin{array}{c}-0.014 * * * \\
(-4.127)\end{array}$ & $\begin{array}{c}-0.006 \\
(-1.617)\end{array}$ & $\begin{array}{c}-0.021 * * * \\
(-3.351)\end{array}$ & $\begin{array}{c}-0.026^{* * *} \\
(-5.423)\end{array}$ & $\begin{array}{c}-0.013 * * * \\
(-2.617)\end{array}$ & $\begin{array}{c}-0.020^{* * *} \\
(-3.104)\end{array}$ & $\begin{array}{c}-0.027 * * * \\
(-5.546)\end{array}$ & $\begin{array}{c}-0.014 * * * \\
(-2.590)\end{array}$ \\
\hline SIZE & $\begin{array}{c}-0.002 * * * \\
(-5.533)\end{array}$ & $\begin{array}{c}-0.001 * * * \\
(-4.818)\end{array}$ & $\begin{array}{c}-0.001 * * * \\
(-4.563)\end{array}$ & $\begin{array}{l}-0.001 * \\
(-1.696)\end{array}$ & $\begin{array}{c}0.001 \\
(0.677)\end{array}$ & $\begin{array}{c}0.001 \\
(1.321)\end{array}$ & $\begin{array}{c}-0.001 \\
(-1.411)\end{array}$ & $\begin{array}{c}0.001 \\
(0.961)\end{array}$ & $\begin{array}{c}0.001 \\
(1.473)\end{array}$ \\
\hline LNGDPC & & $\begin{array}{c}-0.003 * * * \\
(-3.977)\end{array}$ & $\begin{array}{l}-0.001 * \\
(-1.938)\end{array}$ & & $\begin{array}{c}-0.005 * * * \\
(-5.427)\end{array}$ & $\begin{array}{c}-0.002 * * * \\
(-2.681)\end{array}$ & & $\begin{array}{c}-0.005 * * * \\
(-5.930)\end{array}$ & $\begin{array}{c}-0.003 * * * \\
(-2.954)\end{array}$ \\
\hline INFL & & $\begin{array}{c}0.483 * * * \\
(11.485)\end{array}$ & $\begin{array}{c}0.467 * * * \\
(11.036)\end{array}$ & & $\begin{array}{c}0.362 * * * \\
(7.890)\end{array}$ & $\begin{array}{c}0.318^{* * *} \\
(7.008)\end{array}$ & & $\begin{array}{c}0.362 * * * \\
(7.630)\end{array}$ & $\begin{array}{c}0.317 * * * \\
(6.770)\end{array}$ \\
\hline MCAP & & & $\begin{array}{c}-0.009 * * * \\
(-8.857)\end{array}$ & & & $\begin{array}{c}-0.014 * * * \\
(-11.123)\end{array}$ & & & $\begin{array}{c}-0.016^{* * *} \\
(-11.548)\end{array}$ \\
\hline Constant & $\begin{array}{c}0.186^{* * *} \\
(23.053)\end{array}$ & $\begin{array}{c}0.161^{* * *} \\
(15.190)\end{array}$ & $\begin{array}{c}0.146^{* * *} \\
(13.967)\end{array}$ & $\begin{array}{c}0.183 * * * \\
(5.171)\end{array}$ & $\begin{array}{c}0.375^{* * *} \\
(30.793)\end{array}$ & $\begin{array}{c}0.353 * * * \\
(29.182)\end{array}$ & $\begin{array}{c}0.183 * * * \\
(5.184)\end{array}$ & $\begin{array}{c}0.208^{* * *} \\
(5.578)\end{array}$ & $\begin{array}{c}0.185^{* * *} \\
(4.968)\end{array}$ \\
\hline Observations & 16,776 & 16,776 & 16,776 & 8,998 & 8,998 & 8,998 & 8,754 & 8,754 & 8,754 \\
\hline R-squared & 0.284 & 0.257 & 0.260 & 0.330 & 0.254 & 0.263 & 0.333 & 0.257 & 0.267 \\
\hline $\begin{array}{l}\text { Country } \\
\text { dummies } \\
\text { Year dummies }\end{array}$ & $\begin{array}{l}\text { Yes } \\
\text { Yes }\end{array}$ & $\begin{array}{l}\text { No } \\
\text { Yes }\end{array}$ & $\begin{array}{l}\text { No } \\
\text { Yes }\end{array}$ & $\begin{array}{l}\text { Yes } \\
\text { Yes }\end{array}$ & $\begin{array}{l}\text { No } \\
\text { Yes }\end{array}$ & $\begin{array}{l}\text { No } \\
\text { Yes }\end{array}$ & $\begin{array}{l}\text { Yes } \\
\text { Yes }\end{array}$ & $\begin{array}{l}\text { No } \\
\text { Yes }\end{array}$ & $\begin{array}{l}\text { No } \\
\text { Yes }\end{array}$ \\
\hline $\begin{array}{l}\text { his table reports cr } \\
\text { pendent variable } \\
\text { 2. The } C A P I T A L_{t} \\
\text { lagged bank-level } \\
\text { gged bank-level co } \\
\text { d MCAP. The tota } \\
\text { ta sources for all t } \\
\text { vels, respectively. }\end{array}$ & $\begin{array}{l}\text { oss-sectional } \\
\text { COE is a prox } \\
-1 \text { variables c } \\
\text { l and/or lagge } \\
\text { ontrol variabl } \\
\text { al sample con } \\
\text { he variables. }\end{array}$ & $\begin{array}{l}\text { egression res } \\
\text { for the cost } \\
\text { nsist of eithe } \\
\text { country-lev } \\
\text { s are: PROV, } \\
\text { ists of } 16,77 \\
\text { Beneath each }\end{array}$ & $\begin{array}{l}\text { s of the fol } \\
\text { equity calc } \\
\text { gged } E Q \\
\text { ariables. F } \\
\text { JEFF, ROA } \\
\text { bservations } \\
\text { efficient is }\end{array}$ & $\begin{array}{l}\text { owing mode } \\
\text { ulated as the } \\
I T T Y \text {, or TIE } \\
\mathrm{E} \text { is the set } \\
\text {, DEP, and } \\
\text { from } 62 \text { cot } \\
\text { the robust } t \text { - }\end{array}$ & $\begin{array}{l}O E_{t}=\alpha_{0} \\
\text { rage of the } \\
\text { or TOTCAI } \\
\text { red effects } \\
\text {. The lagg } \\
\text { es between } \\
\text { stic. } *, * * \text {, }\end{array}$ & $\begin{array}{l}\text { CAPIT AL } \\
\text { implied c } \\
\text { e set of cc } \\
\text { my variab } \\
\text { untry-lev } \\
1 \text { and } 201 \\
\text { *** indica }\end{array}$ & $\begin{array}{l}-1+\beta_{2} \mathrm{COI} \\
\text { t of capital } \\
\text { rol variabl } \\
\text { at the cou } \\
\text { control var } \\
\text { Appendix } \\
\text { significanc }\end{array}$ & $\begin{array}{l}R O L S_{t-1}+ \\
\text { lodels descr } \\
\text { (CONTROI } \\
\text { ry and/or ye } \\
\text { bles are: LN } \\
\text { provides de } \\
\text { at the } 10 \% \text {, }\end{array}$ & $\begin{array}{l}E+\varepsilon_{t} . \text { The } \\
\text { d in Section } \\
-1 \text { ) consist } \\
\text { levels. The } \\
\text { DPC, INF, } \\
\text { itions and } \\
0 \text {, and } 1 \%\end{array}$ \\
\hline
\end{tabular}

\section{Robustness Checks}

In this section, we subject our main finding of a negative impact of bank capital on the cost of equity to a variety of robustness tests. We first check the robustness of our results to additional control variables. Next, we use alternative measures of the cost of equity to check whether our findings are sensitive to the use of the specific cost of equity measure, COE. We then estimate the cost of equity model using alternative methods to address potential endogeneity issues that might have biased our initial results. Finally, we test the robustness of our results to the composition of our sample. Interestingly, our main results are robust to all these checks. Table 3 reports our estimation results when we include additional control variables. In columns (1)-(6), we add controls for market risk, as this has been shown by 
prior literature to impact the cost of equity (e.g., Botosan et al., 2011; Chen et al., 2016). In particular, in columns (1)-(3), we use the standard deviation of a bank's stock returns (RSTD) as a measure of market risk and include it as an additional variable in our cost of equity model. The coefficient estimate on RSTD appears positive and significant at the 1 percent level only in column 1, where we use EQUITY as a measure of capital. Our main variable of interest, EQUITY, TIER1, or TOTCAP, continues to have a negative and significant association with COE across columns (1)-(3). In columns (4)-(6), we replace RSTD with the stock beta, BETA, as a measure of the market risk of equity. The BETA coefficient is positive and highly significant across columns (4)-(6), regardless of the bank capital measure we use. This result is consistent with theoretical predictions suggesting that a firm's cost of equity should rise with its systematic risk. Importantly, the coefficient estimates for our three bank capital variables continue to be negative and significant. The economic impacts of EQUITY, TIER1, and TOTCAP on the cost of equity are the same as those reported in Table 2. This result suggests that, apart from the indirect effect it might exert through stock beta (as suggested by Baker and Wurgler, 2013), bank capital has a significant direct effect on a bank's cost of equity. In columns (7)-(9), we include the stock market turnover, MTOV, as a control for stock market liquidity. Prior literature on nonbanking firms' cost of equity suggests that firms listed in stock markets with a higher liquidity levels face lower costs of equity (e.g., Belkhir et al., 2019; Saad and Samet, 2017). Our estimations in column (7) corroborate this finding for banking firms. Using EQUTIY as a measure of bank capital, we estimate a negative and significant impact of MTOV on bank cost of equity. Yet, this does not alter our main conclusion concerning the bank-capital-cost of equity relationship, as we continue to find a negative and significant coefficient estimate for each of the bank capital variables (EQUITY, TIER1, and TOTCAP).

In columns (10)-(12), we report the results of adding the ratio of nonperforming loans to total loans (NPL) as a control variable for the quality of a bank's assets. Our estimations show that NPL is positively and highly significantly associated with COE, suggesting that banks with more nonperforming loans incur a higher cost of equity. This, however, does not affect our main finding of a negative and significant relationship between our three measures of bank capital and the cost of equity; we continue to report negative coefficient estimates for EQUITY, TIER1, and TOTCAP. Finally, in line with Berger et al. (2018), in columns (13)(15), we control for a bank's book-to-market ratio (BTM) and find that banks with a higher BTMs bear a higher cost of equity. Nonetheless, the reported negative association between bank capital and the cost of equity is unaffected by this additional control variable. 


\begin{tabular}{|c|c|c|c|c|c|c|c|c|c|}
\hline \multicolumn{10}{|c|}{ Table 3. Robustness Tests Controlling for Additional Variables } \\
\hline & (1) & (2) & (3) & (4) & (5) & (6) & (7) & (8) & (9) \\
\hline VARIABLES & $C O E$ & $C O E$ & $C O E$ & $C O E$ & $C O E$ & COE & $C O E$ & $C O E$ & $C O E$ \\
\hline EQUITY & $\begin{array}{c}-0.198 * * * \\
(-8.432)\end{array}$ & & & $\begin{array}{c}-0.190 * * * \\
(-8.030)\end{array}$ & & & $\begin{array}{c}-0.213 * * * \\
(-8.532)\end{array}$ & & \\
\hline TIER1 & \multirow{2}{*}{\multicolumn{2}{|c|}{$\begin{array}{c}-0.038 * * * \\
(-4.982)\end{array}$}} & & & $\begin{array}{c}-0.039 * * * \\
(-4.088)\end{array}$ & & \multirow{2}{*}{\multicolumn{2}{|c|}{$\begin{array}{c}-0.041 * * * \\
(-4.246)\end{array}$}} & \\
\hline TOTCAP & & & $\begin{array}{c}-0.036 * * * \\
(-4.906)\end{array}$ & & & $\begin{array}{c}-0.039 * * * \\
(-3.638)\end{array}$ & & & $\begin{array}{c}-0.042 * * * \\
(-4.302)\end{array}$ \\
\hline PROV & $\begin{array}{c}0.014 * * * \\
(10.998)\end{array}$ & $\begin{array}{c}0.014 * * * \\
(8.410)\end{array}$ & $\begin{array}{c}0.014 * * * \\
(8.191)\end{array}$ & $\begin{array}{c}0.014 * * * \\
(9.026)\end{array}$ & $\begin{array}{c}0.015 * * * \\
(7.506)\end{array}$ & $\begin{array}{c}0.014 * * * \\
(7.135)\end{array}$ & $\begin{array}{c}0.014 * * * \\
(10.265)\end{array}$ & $\begin{array}{c}0.014 * * * \\
(8.719)\end{array}$ & $\begin{array}{c}0.014 * * * \\
(8.510)\end{array}$ \\
\hline INEFF & $\begin{array}{c}-0.116 \\
(-0.996)\end{array}$ & $\begin{array}{c}-0.077 \\
(-0.501)\end{array}$ & $\begin{array}{c}-0.063 \\
(-0.398)\end{array}$ & $\begin{array}{c}-0.302 * * * \\
(-2.712)\end{array}$ & $\begin{array}{l}-0.209^{*} \\
(-1.710)\end{array}$ & $\begin{array}{c}-0.171 \\
(-1.357)\end{array}$ & $\begin{array}{c}-0.084 \\
(-0.648)\end{array}$ & $\begin{array}{c}-0.091 \\
(-0.571)\end{array}$ & $\begin{array}{c}-0.068 \\
(-0.412)\end{array}$ \\
\hline ROA & $\begin{array}{c}-0.481 * * * \\
(-3.611)\end{array}$ & $\begin{array}{c}-0.958 * * * \\
(-6.270)\end{array}$ & $\begin{array}{c}-0.996 * * * \\
(-6.233)\end{array}$ & $\begin{array}{c}-0.367 * * \\
(-2.254)\end{array}$ & $\begin{array}{c}-0.566^{* * * *} \\
(-2.891)\end{array}$ & $\begin{array}{c}-0.591 * * * \\
(-2.803)\end{array}$ & $\begin{array}{c}-0.753 * * * \\
(-5.285)\end{array}$ & $\begin{array}{c}-1.016^{* * * *} \\
(-6.376)\end{array}$ & $\begin{array}{c}-1.057 * * * \\
(-6.345)\end{array}$ \\
\hline DEP & $\begin{array}{c}-0.004 \\
(-0.767)\end{array}$ & $\begin{array}{c}-0.010 \\
(-1.534)\end{array}$ & $\begin{array}{c}-0.009 \\
(-1.403)\end{array}$ & $\begin{array}{c}-0.016^{* * *} \\
(-3.547)\end{array}$ & $\begin{array}{c}-0.042 * * * \\
(-9.020)\end{array}$ & $\begin{array}{c}-0.043 * * * \\
(-8.859)\end{array}$ & $\begin{array}{l}-0.010^{*} \\
(-1.958)\end{array}$ & $\begin{array}{l}-0.012^{*} \\
(-1.939)\end{array}$ & $\begin{array}{l}-0.011^{*} \\
(-1.655)\end{array}$ \\
\hline SIZE & $\begin{array}{c}-0.001 * * * \\
(-3.061)\end{array}$ & $\begin{array}{c}0.001 \\
(1.387)\end{array}$ & $\begin{array}{c}0.001 \\
(1.531)\end{array}$ & $\begin{array}{c}-0.001 \\
(-1.331)\end{array}$ & $\begin{array}{c}-0.001 \\
(-1.612)\end{array}$ & $\begin{array}{l}-0.000 \\
(-1.243)\end{array}$ & $\begin{array}{c}-0.002 * * * \\
(-4.396)\end{array}$ & $\begin{array}{c}0.000 \\
(0.077)\end{array}$ & $\begin{array}{c}0.000 \\
(0.371)\end{array}$ \\
\hline LNGDPC & $\begin{array}{c}-0.001^{*} \\
(-1.729)\end{array}$ & $\begin{array}{c}-0.002 * \\
(-1.748)\end{array}$ & $\begin{array}{c}-0.002 * * \\
(-2.043)\end{array}$ & $\begin{array}{c}0.002 * * * \\
(2.593)\end{array}$ & $\begin{array}{c}-0.001 \\
(-0.450)\end{array}$ & $\begin{array}{c}-0.001 \\
(-0.713)\end{array}$ & $\begin{array}{c}-0.003^{* * *} \\
(-3.434)\end{array}$ & $\begin{array}{c}-0.002 * * \\
(-2.303)\end{array}$ & $\begin{array}{c}-0.003 * * \\
(-2.497)\end{array}$ \\
\hline INFL & $\begin{array}{c}0.473 * * * \\
(9.929)\end{array}$ & $\begin{array}{c}0.342 * * * \\
(6.467)\end{array}$ & $\begin{array}{c}0.337 * * * \\
(6.202)\end{array}$ & $\begin{array}{c}0.474 * * * \\
(8.312)\end{array}$ & $\begin{array}{c}0.130 * * * \\
(2.972)\end{array}$ & $\begin{array}{c}0.133^{* * *} \\
(2.914)\end{array}$ & $\begin{array}{c}0.410 * * * \\
(8.331)\end{array}$ & $\begin{array}{c}0.342 * * * \\
(6.308)\end{array}$ & $\begin{array}{c}0.339 * * * \\
(6.102)\end{array}$ \\
\hline MCAP & $\begin{array}{c}-0.012 * * * \\
(-8.499)\end{array}$ & $\begin{array}{c}-0.018 * * * \\
(-9.377)\end{array}$ & $\begin{array}{c}-0.020 * * * \\
(-9.686)\end{array}$ & $\begin{array}{c}-0.008 * * * \\
(-6.919)\end{array}$ & $\begin{array}{c}-0.007 * * * \\
(-6.688)\end{array}$ & $\begin{array}{c}-0.009 * * * \\
(-7.548)\end{array}$ & $\begin{array}{c}-0.014 * * * \\
(-8.499)\end{array}$ & $\begin{array}{c}-0.018 * * * \\
(-9.436)\end{array}$ & $\begin{array}{c}-0.020 * * * \\
(-9.812)\end{array}$ \\
\hline RSTD & $\begin{array}{c}0.024 * * * \\
(6.587)\end{array}$ & $\begin{array}{c}0.009^{*} \\
(1.833)\end{array}$ & $\begin{array}{c}0.009^{*} \\
(1.710)\end{array}$ & & & & & & \\
\hline BETA & & & & $\begin{array}{c}0.002 * * \\
(1.972)\end{array}$ & $\begin{array}{c}0.008 * * * \\
(5.065)\end{array}$ & $\begin{array}{c}0.008 * * * \\
(5.044)\end{array}$ & & & \\
\hline MTOV & & & & & & & $\begin{array}{c}0.001 * * \\
(2.126)\end{array}$ & $\begin{array}{c}-0.001 \\
(-0.110)\end{array}$ & $\begin{array}{c}-0.001 \\
(-0.099)\end{array}$ \\
\hline \multicolumn{10}{|l|}{ NPL } \\
\hline \multicolumn{10}{|l|}{ ВTM } \\
\hline Constant & $\begin{array}{l}0.131 * * * \\
(11.917)\end{array}$ & $\begin{array}{c}0.226^{* * * *} \\
(3.996)\end{array}$ & $\begin{array}{c}0.140 * * * \\
(8.024)\end{array}$ & $\begin{array}{c}0.107 * * * \\
(7.946)\end{array}$ & $\begin{array}{c}0.146 * * * \\
(5.017)\end{array}$ & $\begin{array}{l}0.139 * * * \\
(9.303)\end{array}$ & $\begin{array}{l}0.171 * * * \\
(15.842)\end{array}$ & $\begin{array}{c}0.160 * * * \\
(11.143)\end{array}$ & $\begin{array}{c}0.165 * * * \\
(10.555)\end{array}$ \\
\hline Observations & 12,337 & 7,028 & 6,869 & 8,937 & 5,864 & 5,713 & 8,622 & 6,431 & 6,282 \\
\hline R-squared & 0.279 & 0.273 & 0.276 & 0.296 & 0.308 & 0.315 & 0.288 & 0.273 & 0.276 \\
\hline Year dummy & Yes & Yes & Yes & Yes & Yes & Yes & Yes & Yes & Yes \\
\hline $\begin{array}{l}\text { This table report } \\
\text { dependent variabl } \\
\text { The CAPITAL } L_{t-1} \\
\text { bank-level and la } \\
\text { variables are: PR } \\
\text { INF, and MCAP. } \\
\text { data sources for a } \\
\text { respectively. }\end{array}$ & $\begin{array}{l}\text { ross-sectional } \\
\text { COE is a prox } \\
\text { ariables consis } \\
\text { ed country-lev } \\
\text {, INEFF, RO } \\
\text { he total sample } \\
\text { he variables. }\end{array}$ & $\begin{array}{l}\text { regression res } \\
y \text { for the cost } \\
t \text { of either lag } \\
\text { el variables. I } \\
\text { A, DEP, SIZE } \\
\text { consists of } 1 \\
\text { 3eneath each }\end{array}$ & $\begin{array}{l}\text { ults of the foll } \\
\text { f equity calcu } \\
\text { ed EQUITY, } \\
\mathrm{E} \text { is the set of } \\
\text { RSTD, BET } \\
, 776 \text { observat } \\
\text { oefficient is t }\end{array}$ & $\begin{array}{l}\text { wing model: } \\
\text { ated as the av } \\
\text { or TIER } 1 \text {, or } \\
\text { fixed effects } \\
\text { MTOV, NP } \\
\text { ons from } 62 \text { c } \\
\text { e robust } t \text {-sta }\end{array}$ & $\begin{array}{l}C^{C O E_{t}}=\alpha_{0} \\
\text { yrage of the } \mathrm{f} \\
\text { TOTCAP. The } \\
\text { dummy variab } \\
\mathrm{L} \text {, and BTM. } \\
\text { countries betw } \\
\text { tistic. } *, * * \text {, a }\end{array}$ & $\begin{array}{l}+\beta_{1} \text { CAPITAI } \\
\text { our implied ce } \\
\text { set of control } \\
\text { les at the year } \\
\text { The lagged c } \\
\text { veen } 1991 \text { and } \\
\text { nd } * * * \text { indicat }\end{array}$ & $\begin{array}{l}t-1+\beta_{2} \mathrm{CON} \\
\text { st of capital n } \\
\text { variables }(\mathrm{CO} \\
\text { level. The lag } \\
\text { untry-level ce } \\
\text { 2017. Appenc } \\
\text { significance }\end{array}$ & $\begin{array}{l}R O L S_{t-1}+ \\
\text { odels descril } \\
\text { VTROLS } \\
\text { ted bank-1ev } \\
\text { ntrol variabl } \\
\text { x A provide } \\
\text { tt the } 10 \%, 5\end{array}$ & $\begin{array}{l}F E+\varepsilon_{t} . \text { The } \\
\text { bed in Section } 2.2 \text {. } \\
\text { consist of lagged } \\
\text { el control } \\
\text { les are: LNGDPC, } \\
\text { s definitions and } \\
\% \text {, and } 1 \% \text { levels, }\end{array}$ \\
\hline
\end{tabular}




\begin{tabular}{|c|c|c|c|c|c|c|}
\hline & (10) & (11) & (12) & (13) & (14) & (15) \\
\hline VARIABLES & $C O E$ & $C O E$ & $C O E$ & $C O E$ & $C O E$ & $C O E$ \\
\hline EQUITY & $\begin{array}{c}-0.176 * * * \\
(-9.042)\end{array}$ & & & $\begin{array}{c}-0.175^{* * *} \\
(-8.488)\end{array}$ & & \\
\hline TIER1 & & $\begin{array}{c}-0.029 * * * \\
(-4.355)\end{array}$ & & & $\begin{array}{c}-0.029 * * * \\
(-4.137)\end{array}$ & \\
\hline TOTCAP & & & $\begin{array}{c}-0.030 * * * \\
(-4.399)\end{array}$ & & & $\begin{array}{c}-0.030 * * * \\
(-4.345)\end{array}$ \\
\hline PROV & & & & $\begin{array}{c}0.014 * * * \\
(12.157)\end{array}$ & $\begin{array}{c}0.014 * * * \\
(9.005)\end{array}$ & $\begin{array}{c}0.014 * * * \\
(8.774)\end{array}$ \\
\hline INEFF & $\begin{array}{c}0.022 \\
(0.254)\end{array}$ & $\begin{array}{c}0.105 \\
(0.922)\end{array}$ & $\begin{array}{c}0.106 \\
(0.908)\end{array}$ & $\begin{array}{l}-0.019 \\
(-0.177)\end{array}$ & $\begin{array}{c}-0.030 \\
(-0.211)\end{array}$ & $\begin{array}{l}-0.008 \\
(-0.056)\end{array}$ \\
\hline ROA & $\begin{array}{c}-0.863 * * * \\
(-7.225)\end{array}$ & $\begin{array}{c}-1.168 * * * \\
(-8.479)\end{array}$ & $\begin{array}{c}-1.199 * * * \\
(-8.279)\end{array}$ & $\begin{array}{c}-0.519 * * * \\
(-4.203)\end{array}$ & $\begin{array}{c}-0.976^{* * * *} \\
(-6.801)\end{array}$ & $\begin{array}{c}-1.016^{* * *} \\
(-6.766)\end{array}$ \\
\hline DEP & $\begin{array}{c}-0.010 * * \\
(-2.406)\end{array}$ & $\begin{array}{l}-0.007 \\
(-1.300)\end{array}$ & $\begin{array}{l}-0.007 \\
(-1.324)\end{array}$ & $\begin{array}{c}-0.002 \\
(-0.384)\end{array}$ & $\begin{array}{c}-0.008 \\
(-1.466)\end{array}$ & $\begin{array}{l}-0.009 \\
(-1.455)\end{array}$ \\
\hline SIZE & $\begin{array}{c}-0.001 * * * \\
(-3.615)\end{array}$ & $\begin{array}{c}0.001^{* * *} \\
(2.654)\end{array}$ & $\begin{array}{c}0.001 * * * \\
(2.752)\end{array}$ & $\begin{array}{c}-0.001 * * * \\
(-3.454)\end{array}$ & $\begin{array}{l}0.001 * \\
(1.702)\end{array}$ & $\begin{array}{l}0.001^{*} \\
(1.782)\end{array}$ \\
\hline LNGDPC & $\begin{array}{c}-0.001 \\
(-1.512)\end{array}$ & $\begin{array}{c}-0.002 * * \\
(-2.428)\end{array}$ & $\begin{array}{c}-0.002 * * * \\
(-2.637)\end{array}$ & $\begin{array}{c}-0.002 * * * \\
(-2.972)\end{array}$ & $\begin{array}{c}-0.003 * * * \\
(-2.810)\end{array}$ & $\begin{array}{c}-0.003 * * * \\
(-3.096)\end{array}$ \\
\hline INFL & $\begin{array}{c}0.564 * * * \\
(12.348)\end{array}$ & $\begin{array}{c}0.404 * * * \\
(8.946)\end{array}$ & $\begin{array}{c}0.399 * * * \\
(8.650)\end{array}$ & $\begin{array}{c}0.471 * * * \\
(10.454)\end{array}$ & $\begin{array}{c}0.354 * * * \\
(7.258)\end{array}$ & $\begin{array}{c}0.349 * * * \\
(6.982)\end{array}$ \\
\hline MCAP & $\begin{array}{c}-0.010^{* * *} \\
(-8.272)\end{array}$ & $\begin{array}{c}-0.013^{* * *} \\
(-9.642)\end{array}$ & $\begin{array}{c}-0.014 * * * \\
(-9.933)\end{array}$ & $\begin{array}{c}-0.010^{* * *} \\
(-8.262)\end{array}$ & $\begin{array}{c}-0.015^{* * *} \\
(-9.850)\end{array}$ & $\begin{array}{c}-0.016^{* * *} \\
(-10.378)\end{array}$ \\
\hline NPL & $\begin{array}{c}0.003 * * * \\
(10.646)\end{array}$ & $\begin{array}{c}0.003 * * * \\
(8.429)\end{array}$ & $\begin{array}{c}0.003 * * * \\
(8.012)\end{array}$ & & & \\
\hline BTM & & & & $\begin{array}{c}0.001 * * * \\
(8.179)\end{array}$ & $\begin{array}{c}0.001 * * * \\
(5.284)\end{array}$ & $\begin{array}{c}0.001 * * * \\
(5.010)\end{array}$ \\
\hline Constant & $\begin{array}{c}0.153 * * * \\
(13.341)\end{array}$ & $\begin{array}{c}0.255^{* * *} * \\
(4.842)\end{array}$ & $\begin{array}{c}0.378 * * * \\
(32.184)\end{array}$ & $\begin{array}{c}0.143 * * * \\
(12.739)\end{array}$ & $\begin{array}{c}0.204 * * * \\
(3.093)\end{array}$ & $\begin{array}{c}0.235 * * * \\
(4.181)\end{array}$ \\
\hline Observations & 14,474 & 8,627 & 8,427 & 13,815 & 7,867 & 7,682 \\
\hline R-squared & 0.272 & 0.249 & 0.252 & 0.281 & 0.276 & 0.280 \\
\hline Year dummy & Yes & Yes & Yes & Yes & Yes & Yes \\
\hline
\end{tabular}

CInternational Monetary Fund. Not for Redistribution 
In Table 4, we investigate whether our results are sensitive to the specific cost of equity measure we have used so far. As a reminder, $\mathrm{COE}$ is calculated as the arithmetic average of four implied cost of equity measures $\left(r_{C T}, r_{G L S}, r_{E S}, r_{O J N}\right)$. To alleviate the potential effect of this specific cost of equity measure on our results, we re-estimate the cost of equity model using different measures. In columns (1)-(12), we verify that our results continue to hold if we use the individual measures of the cost of equity instead of the average of the four measures. The reported results reveal that bank capital (EQUITY, TIER1, and TOTCAP) has a negative and significant effect on each of the individual cost of equity measures.

\begin{tabular}{|c|c|c|c|c|c|c|c|c|c|}
\hline \multicolumn{10}{|c|}{ Table 4. Alternative Measures of the Cost of Equity and Risk Premium } \\
\hline VARIABLES & $\begin{array}{l}(1) \\
\text { RCT }\end{array}$ & $\begin{array}{l}\text { (2) } \\
\text { RCT }_{\text {C }}\end{array}$ & $\begin{array}{l}\text { (3) } \\
\mathbf{R}_{\mathrm{CT}}\end{array}$ & $\begin{array}{l}\text { (4) } \\
\text { RES }\end{array}$ & $\begin{array}{l}\text { (5) } \\
\text { RES }\end{array}$ & $\begin{array}{l}\text { (6) } \\
\text { RES }\end{array}$ & $\begin{array}{c}\text { (7) } \\
\text { RGLS }\end{array}$ & $\begin{array}{c}(8) \\
\text { RGLS }\end{array}$ & $\begin{array}{c}(9) \\
\text { RGLS }\end{array}$ \\
\hline EQUITY & $\begin{array}{c}-0.269 * * * \\
(-12.661)\end{array}$ & & & $\begin{array}{c}-0.208 * * * \\
(-7.444)\end{array}$ & & & $\begin{array}{c}-0.102 * * * \\
(-7.443)\end{array}$ & & \\
\hline TOTCAP & & $\begin{array}{c}-0.028 * * * \\
(-3.590)\end{array}$ & & & $\begin{array}{c}-0.040 * * * \\
(-4.281)\end{array}$ & & & $\begin{array}{c}-0.011 * * * \\
(-2.646)\end{array}$ & \\
\hline TIER1 & & & $\begin{array}{c}-0.027 * * * \\
(-3.468)\end{array}$ & & & $\begin{array}{c}-0.038 * * * \\
(-4.208)\end{array}$ & & & $\begin{array}{c}-0.013 * * * \\
(-3.357)\end{array}$ \\
\hline PROV & $\begin{array}{l}0.002 * \\
(1.801)\end{array}$ & $\begin{array}{c}0.001 \\
(1.408)\end{array}$ & $\begin{array}{c}0.001 \\
(1.129)\end{array}$ & $\begin{array}{c}0.027 * * * \\
(16.504)\end{array}$ & $\begin{array}{c}0.029 * * * \\
(11.133)\end{array}$ & $\begin{array}{c}0.030^{* * *} \\
(11.691)\end{array}$ & $\begin{array}{c}0.002 * * * \\
(2.796)\end{array}$ & $\begin{array}{c}0.002 * * \\
(1.960)\end{array}$ & $\begin{array}{c}0.002 * * \\
(2.034)\end{array}$ \\
\hline INEFF & $\begin{array}{c}-0.338^{* * *} \\
(-2.910)\end{array}$ & $\begin{array}{c}-0.608 * * * \\
(-3.973)\end{array}$ & $\begin{array}{c}-0.619 * * * \\
-4.140)\end{array}$ & $\begin{array}{c}-0.116 \\
(-0.948)\end{array}$ & $\begin{array}{c}0.099 \\
(0.534)\end{array}$ & $\begin{array}{c}0.074 \\
(0.415)\end{array}$ & $\begin{array}{c}-0.175^{* *} \\
(-1.986)\end{array}$ & $\begin{array}{c}-0.305^{* * *} \\
(-3.284)\end{array}$ & $\begin{array}{c}-0.340 * * * \\
(-3.829)\end{array}$ \\
\hline ROA & $\begin{array}{l}1.267 * * * \\
(12.295)\end{array}$ & $\begin{array}{c}0.765 * * * \\
(8.698)\end{array}$ & $\begin{array}{c}0.744 * * * \\
(8.421)\end{array}$ & $\begin{array}{c}-1.424 * * * \\
(-8.427)\end{array}$ & $\begin{array}{c}-2.127 * * * \\
(-8.518)\end{array}$ & $\begin{array}{c}-2.005^{* * *} * \\
(-8.430)\end{array}$ & $\begin{array}{c}-0.288 * * * \\
(-4.033)\end{array}$ & $\begin{array}{c}-0.512 * * * \\
(-5.901)\end{array}$ & $\begin{array}{c}-0.519 * * * \\
(-6.334)\end{array}$ \\
\hline DEP & $\begin{array}{c}-0.001 \\
(-0.184)\end{array}$ & $\begin{array}{c}-0.002 \\
(-0.299)\end{array}$ & $\begin{array}{l}-0.003 \\
(-0.474)\end{array}$ & $\begin{array}{c}-0.010 * * \\
(-2.028)\end{array}$ & $\begin{array}{c}-0.016 * * \\
(-2.066)\end{array}$ & $\begin{array}{c}-0.016^{* *} \\
(-2.132)\end{array}$ & $\begin{array}{c}-0.020 * * * \\
(-7.529)\end{array}$ & $\begin{array}{c}-0.036 * * * \\
(-8.617)\end{array}$ & $\begin{array}{c}-0.036^{* * * *} \\
(-8.644)\end{array}$ \\
\hline SIZE & $\begin{array}{l}0.001 * \\
(1.890)\end{array}$ & $\begin{array}{c}0.003^{* * *} \\
(9.026)\end{array}$ & $\begin{array}{c}0.003^{* * *} \\
(8.749)\end{array}$ & $\begin{array}{c}-0.002^{* * * *} \\
(-4.818)\end{array}$ & $\begin{array}{c}-0.001 \\
(-1.259)\end{array}$ & $\begin{array}{c}-0.001 \\
(-1.439)\end{array}$ & $\begin{array}{c}-0.001 * * * \\
(-6.281)\end{array}$ & $\begin{array}{c}-0.001 \\
(-0.335)\end{array}$ & $\begin{array}{c}-0.001 \\
(-0.489)\end{array}$ \\
\hline LGDPC & $\begin{array}{c}-0.002 * * \\
(-2.197)\end{array}$ & $\begin{array}{c}-0.006^{* * *} \\
(-5.441)\end{array}$ & $\begin{array}{c}-0.006^{* * *} \\
(-5.633)\end{array}$ & $\begin{array}{c}0.002 \\
(1.622)\end{array}$ & $\begin{array}{c}-0.001 \\
(-0.553)\end{array}$ & $\begin{array}{c}-0.001 \\
(-0.240)\end{array}$ & $\begin{array}{c}-0.001 \\
(-0.971)\end{array}$ & $\begin{array}{l}-0.001 * \\
(-1.898)\end{array}$ & $\begin{array}{c}-0.001 \\
(-1.579)\end{array}$ \\
\hline INFL & $\begin{array}{l}0.665^{* * * *} \\
(11.678)\end{array}$ & $\begin{array}{c}0.330^{* * *} \\
(4.767)\end{array}$ & $\begin{array}{c}0.342^{* * *} \\
(5.061)\end{array}$ & $\begin{array}{c}0.586 * * * \\
(9.337)\end{array}$ & $\begin{array}{c}0.348 * * * \\
(5.257)\end{array}$ & $\begin{array}{c}0.334 * * * \\
(5.172)\end{array}$ & $\begin{array}{c}0.356 * * * \\
(10.847)\end{array}$ & $\begin{array}{c}0.216^{* * *} \\
(5.875)\end{array}$ & $\begin{array}{c}0.225^{* * *} * \\
(6.292)\end{array}$ \\
\hline MCAP & $\begin{array}{c}-0.009 * * * \\
(-5.884)\end{array}$ & $\begin{array}{c}-0.018 * * * \\
(-7.648)\end{array}$ & $\begin{array}{c}-0.015^{* * *} \\
(-6.959)\end{array}$ & $\begin{array}{c}-0.008 * * * \\
(-5.498)\end{array}$ & $\begin{array}{c}-0.014 * * * \\
(-8.138)\end{array}$ & $\begin{array}{c}-0.014 * * * \\
(-8.084)\end{array}$ & $\begin{array}{c}-0.011 * * * \\
(-12.329)\end{array}$ & $\begin{array}{c}-0.016^{* * *} \\
(-15.897)\end{array}$ & $\begin{array}{c}-0.015 * * * \\
(-15.471)\end{array}$ \\
\hline Constant & $\begin{array}{c}0.131^{* * *} \\
(9.355)\end{array}$ & $\begin{array}{c}0.108^{* * *} \\
(5.530)\end{array}$ & $\begin{array}{c}0.107 * * * \\
(5.514)\end{array}$ & $\begin{array}{c}0.124 * * * \\
(7.839)\end{array}$ & $\begin{array}{c}0.264^{* * * *} \\
(3.416)\end{array}$ & $\begin{array}{l}0.639^{* * *} \\
(34.129)\end{array}$ & $\begin{array}{l}0.134 * * * \\
(17.114)\end{array}$ & $\begin{array}{c}0.037^{* * * *} \\
(4.413)\end{array}$ & $\begin{array}{c}0.034 * * * \\
(4.157)\end{array}$ \\
\hline Observations & 12,643 & 7,406 & 7,604 & 16,014 & 8,338 & 8,567 & 14,751 & 7,948 & 8,171 \\
\hline R-squared & 0.245 & 0.174 & 0.168 & 0.315 & 0.363 & 0.359 & 0.210 & 0.252 & 0.247 \\
\hline Year dummy & Yes & Yes & Yes & Yes & Yes & Yes & Yes & Yes & Yes \\
\hline $\begin{array}{l}\text { In Panel A of this Ta } \\
R_{E S}, R_{G L S} \text {, and } R_{O J}, \mathrm{t} \\
\text { Ohlson and Juettner- } \\
\text { Columns (16-18) rep } \\
\text { (RPM) which is calc } \\
\text { countries between } 19 \\
t \text {-statistic. } *, * * \text {, and }\end{array}$ & $\begin{array}{l}\text { le, columns } \\
\text { lat represent } \mathrm{t} \\
\text { Jauroth }(2005 \\
\text { aces } C O E \text { wi } \\
\text { lated as } \mathrm{COE} \\
1 \text { and } 2017 . \text { A } \\
* * \text { indicate si }\end{array}$ & $\begin{array}{l}(1)-(12) \text { repe } \\
\text { the implied co } \\
\text { 5), respective } \\
\text { ith the princip } \\
\text { E minus the } 1 \\
\text { Appendix A p } \\
\text { ignificance at }\end{array}$ & $\begin{array}{l}\text { eat the same } \\
\text { ost of equity } \\
\text { ely. Columns } \\
\text { pal componer } \\
10 \text {-year U.S. } \\
\text { rovides defin } \\
\text { the } 10 \%, 5 \%\end{array}$ & $\begin{array}{l}\text { analysis as i } \\
\text { estimates of } \\
\text { s }(16-18) \text { rep } \\
\text { nt }\left(R_{P C A}\right) \text { of } K \\
\text { Treasury bo } \\
\text { nitions and da } \\
\% \text {, and } 1 \% \text { lev }\end{array}$ & $\begin{array}{l}\text { in Table } 2 \mathrm{mc} \\
\text { Claus and Th } \\
\text { laces } C O E \mathrm{y} \\
R_{C T}, R_{E S}, R_{G} \\
\text { ond yield. Th } \\
\text { ata sources fo } \\
\text { vels, respecti }\end{array}$ & $\begin{array}{l}\text { dels } 3,6 \text {, an } \\
\text { omas }(2001) \text {, } \\
\text { iith the avera } \\
L S \text {, and } R_{O J} . \text { I } \\
\text { e total sample } \\
\text { r all the varia } \\
\text { vely. }\end{array}$ & $\begin{array}{l}\text { d } 9 \text { after repl } \\
\text { Easton }(200 \\
\text { age of } R_{E S} \text { an } \\
\text { Panel B repla } \\
\text { e consists of } \\
\text { ables. Beneatl }\end{array}$ & $\begin{array}{l}\text { lacing } C O E \text { y } \\
\text { 4), Gebhardt } \\
\mathrm{d} R_{G L S} \text { implie } \\
\text { ace COE by t } \\
16,776 \text { obse } \\
\text { heach coeffic }\end{array}$ & $\begin{array}{l}\text { with each of } R_{C T} \text {, } \\
\text { et al. (2001), and } \\
\text { ed cost of equity. } \\
\text { the risk premium } \\
\text { rvations from } 62 \\
\text { cient is the robust }\end{array}$ \\
\hline
\end{tabular}




\begin{tabular}{|c|c|c|c|c|c|c|c|c|c|}
\hline \multicolumn{10}{|c|}{ Table 4. Alternative Measures of the Cost of Equity and Risk Premium (Continued) } \\
\hline \multicolumn{10}{|c|}{ Panel A. Alternative measures of the cost of equity (Concluded) } \\
\hline & (10) & (11) & (12) & (13) & (14) & (15) & (16) & (17) & (18) \\
\hline VARIABLES & RoJn & RoJn & RoJn & RES_GLS & RES_GLS & RES_GLS & RPCA & RPCA & RPCA \\
\hline EQUITY & $\begin{array}{l}-0.129 * * * \\
(-7.206)\end{array}$ & & & $\begin{array}{l}-2.873 * * * \\
(-6.957)\end{array}$ & & & $\begin{array}{l}-6.102 * * * \\
(-9.359)\end{array}$ & & \\
\hline TOTCAP & & $\begin{array}{l}-0.018 * * * \\
(-3.086)\end{array}$ & & & $\begin{array}{l}-0.483 * * * \\
(-3.954)\end{array}$ & & & $\begin{array}{l}-0.776 * * * \\
(-3.695)\end{array}$ & \\
\hline TIER1 & & & $\begin{array}{l}-0.018 * * * \\
(-3.048)\end{array}$ & & & $\begin{array}{l}-0.536 * * * \\
(-4.471)\end{array}$ & & & $\begin{array}{l}-0.886 \\
(-4.14\end{array}$ \\
\hline PROV & $\begin{array}{l}0.014 * * * \\
(15.146)\end{array}$ & $\begin{array}{l}0.013 * * * \\
(11.465)\end{array}$ & $\begin{array}{l}0.014 * * * \\
(11.660)\end{array}$ & $\begin{array}{l}0.241 * * * \\
(12.629)\end{array}$ & $\begin{array}{l}0.249 * * * \\
(10.119)\end{array}$ & $\begin{array}{l}0.258 * * * \\
(10.475)\end{array}$ & $\begin{array}{l}0.300 * * * \\
(10.601)\end{array}$ & $\begin{array}{l}0.295 * * * \\
(8.666)\end{array}$ & $\begin{array}{l}0.300^{*} \\
(8.834\end{array}$ \\
\hline INEFF & $\begin{array}{l}0.117 \\
(1.312)\end{array}$ & $\begin{array}{l}0.376 * * * \\
(2.955)\end{array}$ & $\begin{array}{l}0.363 * * * \\
(2.963)\end{array}$ & $\begin{array}{l}-5.221 * * \\
(-2.512)\end{array}$ & $\begin{array}{l}-5.049 * * \\
(-2.190)\end{array}$ & $\begin{array}{l}-5.918 * * * \\
(-2.659)\end{array}$ & $\begin{array}{l}-3.667 \\
(-1.210)\end{array}$ & $\begin{array}{l}1.173 \\
(0.323)\end{array}$ & $\begin{array}{l}-0.153 \\
(-0.04\end{array}$ \\
\hline ROA & $\begin{array}{l}-0.624 * * * \\
(-5.651)\end{array}$ & $\begin{array}{l}-0.9446 * * * \\
(-7.673)\end{array}$ & $\begin{array}{l}-0.917 * * * \\
(-7.683)\end{array}$ & $\begin{array}{l}-18.896^{* * *} \\
(-8.335)\end{array}$ & $\begin{array}{l}-29.978 * * * \\
(-11.503)\end{array}$ & $\begin{array}{l}-28.648 * * * \\
(-11.342)\end{array}$ & $\begin{array}{l}-7.268^{* *} \\
(-2.295)\end{array}$ & $\begin{array}{l}-25.484 * * * \\
(-8.045)\end{array}$ & $\begin{array}{l}-24.91 \\
\left(-8.09^{\prime}\right.\end{array}$ \\
\hline DEP & $\begin{array}{l}-0.014 * * * \\
(-3.774)\end{array}$ & $\begin{array}{l}-0.027 * * * \\
(-4.594)\end{array}$ & $\begin{array}{l}-0.026 * * * \\
(-4.587)\end{array}$ & $\begin{array}{l}-0.483 * * * \\
(-6.095)\end{array}$ & $\begin{array}{l}-0.802 * * * \\
(-6.136)\end{array}$ & $\begin{array}{l}-0.797 * * * \\
(-6.274)\end{array}$ & $\begin{array}{l}-0.837 * * * \\
(-6.319)\end{array}$ & $\begin{array}{l}-1.274 * * * \\
(-6.378)\end{array}$ & $\begin{array}{l}-1.274 \\
(-6.55\end{array}$ \\
\hline SIZE & $\begin{array}{l}0.001 \\
(0.498)\end{array}$ & $\begin{array}{l}0.001 * * * \\
(2.915)\end{array}$ & $\begin{array}{l}0.001 * * * \\
(3.038)\end{array}$ & $\begin{array}{l}-0.030 * * * \\
(-4.987)\end{array}$ & $\begin{array}{l}-0.005 \\
(-0.681)\end{array}$ & $\begin{array}{l}-0.007 \\
(-0.934)\end{array}$ & $\begin{array}{l}-0.016^{*} \\
(-1.682)\end{array}$ & $\begin{array}{l}0.032 * * * \\
(2.599)\end{array}$ & $\begin{array}{l}0.029^{*} \\
(2.386\end{array}$ \\
\hline LGDPC & $\begin{array}{l}-0.001 \\
(-0.857)\end{array}$ & $\begin{array}{l}-0.003 * * * \\
(-3.061)\end{array}$ & $\begin{array}{l}-0.003 * * * \\
(-2.966)\end{array}$ & $\begin{array}{l}0.016 \\
(0.825)\end{array}$ & $\begin{array}{l}-0.045^{* *} \\
(-2.305)\end{array}$ & $\begin{array}{l}-0.040 * * \\
(-2.055)\end{array}$ & $\begin{array}{l}0.009 \\
(0.282)\end{array}$ & $\begin{array}{l}-0.114 * * * \\
(-4.509)\end{array}$ & $\begin{array}{l}-0.112 \\
(-4.52\end{array}$ \\
\hline INFL & $0.676^{* * *}$ & $0.376^{* * *}$ & $0.377 * * *$ & $13.086^{* * *}$ & $6.598 * * *$ & $6.508 * * *$ & $\begin{array}{l}23.892 * * \\
*\end{array}$ & $12.088^{* * *}$ & 12.106 \\
\hline & $(12.417)$ & $(7.407)$ & $(7.599)$ & (11.597) & $(6.187)$ & $(6.215)$ & $(12.897)$ & $(8.767)$ & (8.957 \\
\hline MCAP & $\begin{array}{l}-0.008 * * * \\
(-7.393)\end{array}$ & $\begin{array}{l}-0.016^{* * *} \\
(-11.257)\end{array}$ & $\begin{array}{l}-0.014 * * * \\
(-10.752)\end{array}$ & $\begin{array}{l}-0.232 * * * \\
(-9.398)\end{array}$ & $\begin{array}{l}-0.396^{* * *} \\
(-14.087)\end{array}$ & $\begin{array}{l}-0.365^{* * *} \\
(-13.774)\end{array}$ & $\begin{array}{l}-0.365 * * * \\
(-9.926)\end{array}$ & $\begin{array}{l}-0.598^{* * *} \\
(-14.205)\end{array}$ & $\begin{array}{l}-0.542 \\
(-13.6\end{array}$ \\
\hline Constant & $\begin{array}{l}0.138 * * * \\
(11.087)\end{array}$ & $\begin{array}{l}0.195 * * * \\
(15.329)\end{array}$ & $\begin{array}{l}0.216^{* * *} \\
(9.176)\end{array}$ & $\begin{array}{l}0.379 \\
(1.470)\end{array}$ & $\begin{array}{l}4.037 * * * \\
(15.736)\end{array}$ & $\begin{array}{l}1.241 * * * \\
(4.189)\end{array}$ & $\begin{array}{l}0.401 \\
(0.981)\end{array}$ & $\begin{array}{l}1.805^{* * *} \\
(4.883)\end{array}$ & $\begin{array}{l}1.716^{*} \\
(4.794\end{array}$ \\
\hline Observations & 15,287 & 7,900 & 8,127 & 13,998 & 7,536 & 7,745 & 11,500 & 6,686 & 6,866 \\
\hline R-squared & 0.296 & 0.264 & 0.260 & 0.323 & 0.365 & 0.360 & 0.339 & 0.302 & 0.298 \\
\hline Year dummy & Yes & Yes & Yes & Yes & Yes & Yes & Yes & Yes & Yes \\
\hline
\end{tabular}




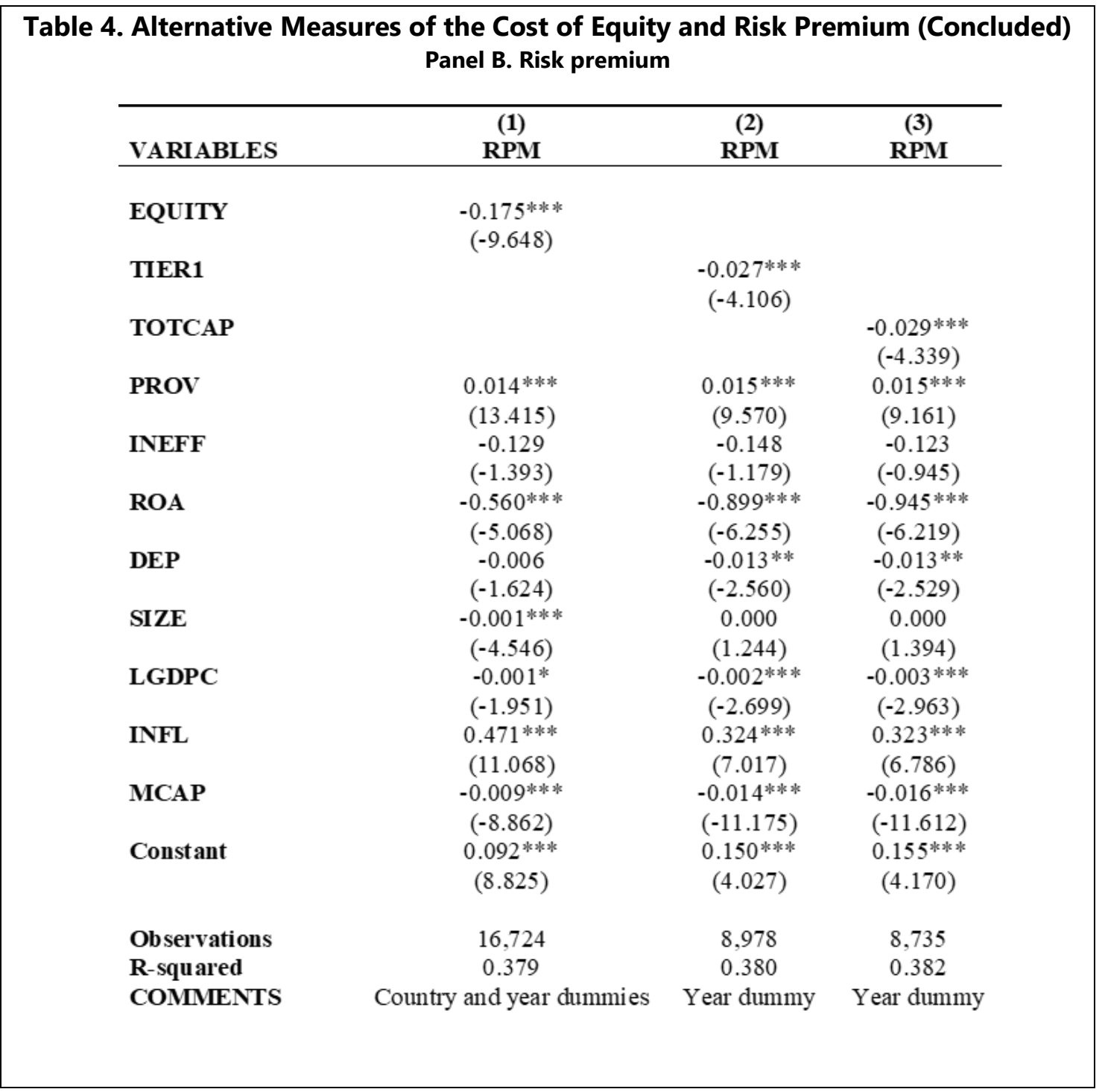

It is worth noting that the estimations of $r_{C T}$ and $r_{O J N}$ assume a long-term growth rate that is computed using the yearly one-year-ahead realized inflation rate. This makes $r_{O J N}$ and $r_{C T}$ especially sensitive to the choice of the long-term growth rate. By contrast, the estimations of $r_{E S}$ and $r_{G L S}$ do not require assumptions about the growth rate beyond the forecast horizon. This concern does not bias our findings, since the results reported for $r_{C T}$ and $r_{O J N}$ (Table 4) are similar to those for $r_{E S}$ and $r_{G L S}$. to further ensure the robustness of our results, in columns (13)-(15), we re-estimate our cost of equity model using the principal component for $r_{E S}$ and $r_{G L S}$. This does not affect our conclusions, as we continue to report negative and significant coefficients for EQUITY, TIER1, and TOTCAP. Further, in columns (16)-(18), we calculate the principal component of the four cost of equity and use it as our dependent variable. The estimations indicate that our three bank capital measures continue to load negative and statistically significant. Together, the results reported in Table 4 alleviate any concerns that our initially reported result of a negative and significant association between bank capital and the cost of equity might have been driven by the way we measure the cost of equity. 
Our sample spans the period 1991-2017, which is characterized by a steady decline in interest rates globally (e.g., Del Negro et al., 2018). One might reasonably suspect that this movement might have driven down required equity returns. Figure 1 suggests that our sample period is also characterized by an upward movement in equity-to-assets ratios. It is thus concerning that these two opposite movements over time might be driving the negative association we uncover between capital ratios and bank cost of equity and potentially generating spurious findings. To ensure that our results are not caused by the declining interest rate environment, all of our regression equations include year dummy variables that control for unobserved time factors that may drive banks' COE. Additionally, in panel B of Table 4, we present the results of our estimations of the cost of equity model, using the risk premium (RPM) as a dependent variable rather than COE. We calculate RPM as the difference between COE and the 10-year U.S. Treasury bond yield. Our results suggest that the risk premium is negatively and significantly associated with each of our three capital measures, alleviating the concern that our initial finding of a negative relationship between bank capital and the cost of equity is driven by the low interest rate environment.

The results we have reported so far might also have been affected by the choice of empirical method used to estimate our cost of equity model. We are particularly concerned that our results suffer from a bias caused by potential bank capital endogeneity. To mitigate this concern, we re-estimate the cost of equity model using three different methods. First, we calculate the bank average of each variable throughout the sample period and estimate the same regression model as the one in Table 2. By construction, the averages of these variables, particularly the capital variables, are less likely to be endogenously determined with the cost of equity. We report the results in Table 5, columns (1)-(3) of panel A. These results continue to support our prior finding that bank capital has a negative, significant influence the cost of equity. Specifically, we find that the average cost of equity is negatively influenced by the bank capital average. This result is valid whether we use EQUITY, TIER1, or TOTCAP as a measure of bank capital.

Second, we use the Fama-MacBeth (1973) methodology to check whether the documented relationship between the cost of equity and bank capital survives alternative estimation methods. First, we estimate yearly cross-sectional regressions with similar specifications to those described in our base regression models in columns (3), (6) and (9) of Table 2. Second, we calculate the time-series averages of the yearly cross-sectional coefficients on bank capital and the other explanatory variables. We correct heteroscedasticity and autocorrelation in the coefficients' time-series and report the Newey-West adjusted $t$-stats. Significant coefficients indicate that bank capital has predictive power in explaining the cross section of the cost of equity. The estimation outputs of the Fama-MacBeth regressions are presented in columns (4)-(6) of Panel A in Table 5. As shown in panel A of Table 5, our findings continue to support the presence of a negative and significant effect of capital on banks' cost of equity. 
Table 5: Endogeneity and Sample Composition Panel A: Endogeneity

\begin{tabular}{|c|c|c|c|c|c|c|c|c|c|}
\hline VARIABLES & $\begin{array}{l}(1) \\
C O E\end{array}$ & $\begin{array}{c}(2) \\
C O E\end{array}$ & $\begin{array}{l}\text { (3) } \\
C O E\end{array}$ & $\begin{array}{l}(4) \\
C O E\end{array}$ & $\begin{array}{c}5) \\
C O E\end{array}$ & $\begin{array}{l}\text { (6) } \\
C O E\end{array}$ & $\begin{array}{l}(7) \\
C O E\end{array}$ & $\begin{array}{c}(8) \\
C O E\end{array}$ & $\begin{array}{l}(9) \\
C O E \\
\end{array}$ \\
\hline EQUITY & $\begin{array}{c}-0.117 * * * \\
(-2.937)\end{array}$ & & & $\begin{array}{c}-0.187 * * * \\
(-6.468)\end{array}$ & & & $\begin{array}{c}-0.218 * * * \\
(-5.420)\end{array}$ & & \\
\hline TIER1 & & $\begin{array}{c}-0.033 * * \\
(-2.325)\end{array}$ & & & $\begin{array}{c}-0.283 * * \\
(-2.129)\end{array}$ & & & $\begin{array}{c}-0.014 * * \\
(-2.157)\end{array}$ & \\
\hline TOTCAP & & & $\begin{array}{c}-0.038 * * \\
(-2.462)\end{array}$ & & & $\begin{array}{c}-0.215 * * \\
(-2.417)\end{array}$ & & & $\begin{array}{r}-0.013 * \\
(-2.171)\end{array}$ \\
\hline PROV & $\begin{array}{c}0.017 * * * \\
(5.134)\end{array}$ & $\begin{array}{c}0.019 * * * \\
(4.578)\end{array}$ & $\begin{array}{c}0.019 * * * \\
(4.484)\end{array}$ & $\begin{array}{c}0.013 * * * \\
(6.974)\end{array}$ & $\begin{array}{c}0.041 \\
(1.135)\end{array}$ & $\begin{array}{c}0.044 \\
(1.153)\end{array}$ & $\begin{array}{c}0.015 * * * \\
(13.550)\end{array}$ & $\begin{array}{c}0.015^{* * *} \\
(8.902)\end{array}$ & $\begin{array}{r}0.015^{* *} \\
(9.323)\end{array}$ \\
\hline INEFF & $\begin{array}{c}0.126 \\
(0.490)\end{array}$ & $\begin{array}{c}-0.088 \\
(-0.275)\end{array}$ & $\begin{array}{c}-0.076 \\
(-0.236)\end{array}$ & $\begin{array}{c}0.045 \\
(0.334)\end{array}$ & $\begin{array}{l}-2.483 \\
(-1.067)\end{array}$ & $\begin{array}{c}-2.886 \\
(-1.109)\end{array}$ & $\begin{array}{l}-0.160^{*} \\
(-1.856)\end{array}$ & $\begin{array}{c}-0.125 \\
(-0.974)\end{array}$ & $\begin{array}{r}-0.140 \\
(-1.137)\end{array}$ \\
\hline ROA & $\begin{array}{c}-1.108^{* * *} \\
(-3.598)\end{array}$ & $\begin{array}{c}-1.167 * * * \\
(-3.260)\end{array}$ & $\begin{array}{c}-1.195 * * * \\
(-3.349)\end{array}$ & $\begin{array}{c}-0.544 * * * \\
(-3.328)\end{array}$ & $\begin{array}{c}-0.319 \\
(-0.815)\end{array}$ & $\begin{array}{c}-0.527 * * * \\
(-3.551)\end{array}$ & $\begin{array}{c}-0.529 * * * \\
(-3.974)\end{array}$ & $\begin{array}{c}-1.000 * * * \\
(-5.962)\end{array}$ & $\begin{array}{r}-0.979 * * \\
(-6.265)\end{array}$ \\
\hline DEP & $\begin{array}{c}-0.004 \\
(-0.395)\end{array}$ & $\begin{array}{c}0.001 \\
(0.085)\end{array}$ & $\begin{array}{c}-0.001 \\
(-0.092)\end{array}$ & $\begin{array}{l}-0.009^{*} \\
(-1.909)\end{array}$ & $\begin{array}{c}0.211 \\
(0.871)\end{array}$ & $\begin{array}{c}0.224 \\
(0.912)\end{array}$ & $\begin{array}{c}-0.004 \\
(-1.148)\end{array}$ & $\begin{array}{c}-0.011 * * \\
(-2.219)\end{array}$ & $\begin{array}{l}-0.010^{*} \\
(-1.940)\end{array}$ \\
\hline SIZE & $\begin{array}{l}-0.001^{*} \\
(-1.646)\end{array}$ & $\begin{array}{c}-0.001 \\
(-0.318)\end{array}$ & $\begin{array}{c}-0.001 \\
(-0.242)\end{array}$ & $\begin{array}{c}-0.002 * * * * \\
(-3.008)\end{array}$ & $\begin{array}{c}-0.004 \\
(-0.486)\end{array}$ & $\begin{array}{c}0.002 \\
(0.247)\end{array}$ & $\begin{array}{c}-0.002 * * * \\
(-4.135)\end{array}$ & $\begin{array}{l}-0.001^{*} \\
(-1.691)\end{array}$ & $\begin{array}{r}-0.001^{*}= \\
(-2.311)\end{array}$ \\
\hline LGDPC & $\begin{array}{l}-0.003^{*} \\
(-1.694)\end{array}$ & $\begin{array}{c}0.001 \\
(0.147)\end{array}$ & $\begin{array}{c}-0.001 \\
(-0.023)\end{array}$ & $\begin{array}{l}-0.003^{*} \\
(-2.028)\end{array}$ & $\begin{array}{c}0.025 \\
(0.138)\end{array}$ & $\begin{array}{c}0.044 \\
(0.225)\end{array}$ & $\begin{array}{l}-0.001 * \\
(-1.811)\end{array}$ & $\begin{array}{c}-0.003 * * * \\
(-3.768)\end{array}$ & $\begin{array}{r}-0.003 * * \\
(-3.391)\end{array}$ \\
\hline INFL & $\begin{array}{c}0.630 * * * \\
(6.341)\end{array}$ & $\begin{array}{c}0.632 * * * \\
(5.268)\end{array}$ & $\begin{array}{c}0.636^{* * *} * \\
(5.274)\end{array}$ & $\begin{array}{c}0.400 * * * \\
(8.007)\end{array}$ & $\begin{array}{c}1.167 \\
(1.558)\end{array}$ & $\begin{array}{l}0.726^{*} \\
(1.975)\end{array}$ & $\begin{array}{c}0.473 * * * \\
(11.248)\end{array}$ & $\begin{array}{c}0.286^{* * *} * \\
(6.622)\end{array}$ & $\begin{array}{r}0.285 * * \\
(6.798)\end{array}$ \\
\hline MCAP & $\begin{array}{c}-0.002 \\
(-0.786)\end{array}$ & $\begin{array}{c}-0.008 * * \\
(-2.225)\end{array}$ & $\begin{array}{c}-0.008 * * \\
(-2.168)\end{array}$ & $\begin{array}{c}-0.008 * * \\
(-2.459)\end{array}$ & $\begin{array}{c}-0.003 \\
(-0.177)\end{array}$ & $\begin{array}{c}-0.001 \\
(-0.085)\end{array}$ & $\begin{array}{c}-0.009 * * * \\
(-8.771)\end{array}$ & $\begin{array}{c}-0.016^{* * *} \\
(-11.502)\end{array}$ & $\begin{array}{r}-0.015^{* *} \\
(-11.443\end{array}$ \\
\hline Constant & $\begin{array}{c}0.153^{* * * *} \\
(6.204)\end{array}$ & $\begin{array}{c}0.112 * * * \\
(4.478)\end{array}$ & $\begin{array}{c}0.119 * * * \\
(4.700)\end{array}$ & $\begin{array}{c}0.166^{* * * *} \\
(11.368)\end{array}$ & $\begin{array}{c}-0.240 \\
(-0.120)\end{array}$ & $\begin{array}{c}-0.467 \\
(-0.216)\end{array}$ & $\begin{array}{c}0.103 * * * \\
(7.220)\end{array}$ & $\begin{array}{c}0.161 * * * \\
(16.266)\end{array}$ & $\begin{array}{r}0.152 * * \\
(15.739\end{array}$ \\
\hline Observations & 2,195 & 1,519 & 1,501 & 16,776 & 8,998 & 8,754 & 16,776 & 8,998 & 8,754 \\
\hline R-squared & 0.286 & 0.302 & 0.302 & 0.300 & 0.470 & 0.467 & 0.265 & 0.272 & 0.265 \\
\hline
\end{tabular}

Panel A of this Table reports endogeneity robustness results. Columns (1)-(3) report the cross-sectional regressions where all variables are averaged by bank. Columns (4)-(6) report the Fama-MacBeath regression results. Columns (7)-(9) report the results of the second stage from the two-stage least square (2 SLS) regressions for the baseline models (3), (6), and (9) of Table 2 where the instrument for each of the three capital variables (EQUITY, TIER1, and TOTCAP) is its mean by country-year excluding the focal bank to mitigate endogeneity. Panel B reports the results for all countries excluding the US in Columns(1)-(3) and the US separately in Columns (4)-(6).The total sample consists of 16,776 observations from 62 countries between 1991 and 2017. Appendix A provides definitions and data sources for all the variables. Beneath each coefficient is the robust $t$-statistic. $*, * *$, and $* * *$ indicate significance at the $10 \%, 5 \%$, and $1 \%$ levels, respectively. 
Table 5: Endogeneity and Sample Composition (Concluded)

Panel B: Estimations excluding banks from the US and separate estimations for the US

\begin{tabular}{|c|c|c|c|c|c|c|}
\hline VARIABLES & $\begin{array}{c}(1) \\
C O E\end{array}$ & $\begin{array}{l}(2) \\
C O E\end{array}$ & $\begin{array}{l}\text { (3) } \\
C O E\end{array}$ & $\begin{array}{l}\text { (4) } \\
C O E\end{array}$ & $\begin{array}{l}\text { (5) } \\
C O E\end{array}$ & $\begin{array}{l}\text { (6) } \\
C O E\end{array}$ \\
\hline EQUITY & $\begin{array}{c}-0.190 * * * \\
(-5.771)\end{array}$ & & & $\begin{array}{c}-0.187 * * * \\
(-9.563)\end{array}$ & & \\
\hline TIER1 & & $\begin{array}{c}-0.007 * * \\
(2.175)\end{array}$ & & & $\begin{array}{c}-0.046 * * * \\
(-5.854)\end{array}$ & \\
\hline TOTCAP & & & $\begin{array}{c}-0.003 * * \\
(-2.187)\end{array}$ & & & $\begin{array}{c}-0.039 * * * \\
(-5.169)\end{array}$ \\
\hline PROV & $\begin{array}{c}0.014 * * * \\
(10.025)\end{array}$ & $\begin{array}{c}0.012 * * * \\
(6.304)\end{array}$ & $\begin{array}{c}0.012 * * * \\
(5.897)\end{array}$ & $\begin{array}{c}0.016 * * * \\
(9.577)\end{array}$ & $\begin{array}{c}0.020 * * * \\
(8.053)\end{array}$ & $\begin{array}{c}0.020^{* * * *} \\
(8.066)\end{array}$ \\
\hline INEFF & $\begin{array}{c}0.024 \\
(0.164)\end{array}$ & $\begin{array}{l}0.373^{*} \\
(1.851)\end{array}$ & $\begin{array}{l}0.395^{*} \\
(1.784)\end{array}$ & $\begin{array}{c}-0.092 \\
(-0.866)\end{array}$ & $\begin{array}{l}-0.324 * * \\
(-1.993)\end{array}$ & $\begin{array}{l}-0.305^{*} \\
(-1.872)\end{array}$ \\
\hline ROA & $\begin{array}{c}-0.269 \\
(-1.639)\end{array}$ & $\begin{array}{c}-0.735 * * * \\
(-3.580)\end{array}$ & $\begin{array}{c}-0.769 * * * \\
(-3.383)\end{array}$ & $\begin{array}{c}-0.936 * * * \\
(-6.784)\end{array}$ & $\begin{array}{c}-0.923 * * * \\
(-4.900)\end{array}$ & $\begin{array}{c}-0.922 * * * \\
(-4.874)\end{array}$ \\
\hline DEP & $\begin{array}{c}0.002 \\
(0.313)\end{array}$ & $\begin{array}{c}-0.002 \\
(-0.300)\end{array}$ & $\begin{array}{c}-0.004 \\
(-0.589)\end{array}$ & $\begin{array}{c}-0.028 * * * \\
(-5.549)\end{array}$ & $\begin{array}{c}-0.028 * * * \\
(-2.827)\end{array}$ & $\begin{array}{c}-0.025 * * * \\
(-2.587)\end{array}$ \\
\hline SIZE & $\begin{array}{c}-0.002 * * * \\
(-3.179)\end{array}$ & $\begin{array}{c}-0.001 * * * \\
(-2.636)\end{array}$ & $\begin{array}{c}-0.001 * * * \\
(-2.864)\end{array}$ & $\begin{array}{c}-0.002 * * * \\
(-6.827)\end{array}$ & $\begin{array}{c}-0.002 * * * \\
(-3.395)\end{array}$ & $\begin{array}{c}-0.001 * * * \\
(-2.975)\end{array}$ \\
\hline LGDPC & $\begin{array}{c}0.001 \\
(0.463)\end{array}$ & $\begin{array}{c}-0.001 \\
(-0.400)\end{array}$ & $\begin{array}{l}-0.001 \\
(-1.002)\end{array}$ & $\begin{array}{l}-0.318^{*} \\
(-1.732)\end{array}$ & $\begin{array}{c}-0.087 \\
(-0.403)\end{array}$ & $\begin{array}{c}-0.078 \\
(-0.361)\end{array}$ \\
\hline INFL & $\begin{array}{c}0.459 * * * \\
(10.664)\end{array}$ & $\begin{array}{c}0.296 * * * \\
(6.299)\end{array}$ & $\begin{array}{c}0.290 * * * \\
(5.946)\end{array}$ & $\begin{array}{l}1.284^{* *} \\
(2.465)\end{array}$ & $\begin{array}{c}1.336 * * * \\
(2.980)\end{array}$ & $\begin{array}{c}1.345^{* * *} \\
(2.976)\end{array}$ \\
\hline MCAP & $\begin{array}{c}-0.009 * * * \\
(-7.955)\end{array}$ & $\begin{array}{c}-0.014 * * * \\
(-11.214)\end{array}$ & $\begin{array}{c}-0.016 * * * \\
(-11.499)\end{array}$ & $\begin{array}{c}-0.043 \\
(-0.680)\end{array}$ & $\begin{array}{c}-0.009 \\
(-0.113)\end{array}$ & $\begin{array}{c}-0.009 \\
(-0.113)\end{array}$ \\
\hline Constant & $\begin{array}{c}0.112 * * * \\
(8.877)\end{array}$ & $\begin{array}{c}0.335 * * * \\
(23.613)\end{array}$ & $\begin{array}{l}0.343 * * * \\
(23.875)\end{array}$ & $\begin{array}{l}3.345^{*} \\
(1.822)\end{array}$ & $\begin{array}{c}1.037 \\
(0.453)\end{array}$ & $\begin{array}{c}0.943 \\
(0.410)\end{array}$ \\
\hline Observation & 8,406 & 4,521 & 4,288 & 8,370 & 4,477 & 4,466 \\
\hline R-squared & 0.231 & 0.238 & 0.241 & 0.299 & 0.305 & 0.304 \\
\hline Year dummies & Yes & Yes & Yes & Yes & Yes & Yes \\
\hline Sample & $\begin{array}{l}\text { Excluding the } \\
\text { US }\end{array}$ & $\begin{array}{c}\text { Excluding the } \\
\text { US }\end{array}$ & $\begin{array}{c}\text { Excluding the } \\
\text { US }\end{array}$ & US & US & US \\
\hline
\end{tabular}

Third, we address the concern that both cost of equity and bank capital variables are jointly and endogenously determined (contemporaneous relation) due to potential missing explanatory variables by estimating two-stage least square, 2SLS, regression models (e.g., Jayaraman and Milbourn, 2012). In the first step, we instrument the bank capital measures with their averages, which are computed at the country-year level, while excluding the focal bank. To ensure that the focal bank is not biasing our instruments, and that the latter are completely exogenous to the bank under examination, we calculate the instruments for every bank by taking the country-year bank capital (EQUITY, TIER1, TOTCAP) averages across all remaining banks. We run key diagnostic tests on the appropriateness of the employed instruments, which we use in the 2SLS's first step. Following Sanderson and Windmeijer (2016), we assess the relevance and strength of the instrument by conducting underidentification and weak identification tests. The under-identification test examines whether the instrument is relevant, whereas the weak identification test determines whether the instrument is weak. We use the Anderson (1951) canonical LM statistic for the underidentification test. Our results show that this test rejects the null hypothesis of underidentification. Having rejected the instruments' under-identification, we then test whether our model is weakly identified (i.e., the instruments are weak). Based on the Cragg-Donald 
(1993) statistic, we reject the null hypothesis that the equations for bank capital instruments are weakly identified. Based on the result that the instruments for the capital variables' instruments are relevant and strong-we re-estimate our cost of equity model using the 2SLS. The results of the second stage estimation are reported in columns (7)-(9) of panel A in Table 5. These results suggest that our main finding continues to hold. In particular, we continue to find a positive and significant coefficient estimate (EQUITY, TIER1, and TOTCAP), supporting the finding that capital has a negative impact on the cost of equity. Overall, the above results mitigate any concerns that our inferences of a negative effect of bank capital on the cost of equity are biased by the potential endogeneity of bank capital.

One potential concern for our empirical analysis is that our results may be driven by our sample's country composition. In particular, about half of the observations in our sample are U.S bank-years. We therefore investigate whether our initial findings are driven by U.S banks by excluding the latter from the sample. The results of this estimation are reported in panel B of Table 5. They indicate that the negative relationship between bank capital and the cost of equity holds for banks outside the U.S. We further supplement this result with an estimation of the bank capital-cost of equity relationship in the sample of U.S banks. We find a negative and significant coefficient estimate on each of our three bank capital measures.

In sum, our evidence of a negative and significant impact of bank capital on the cost of equity survives a variety of robustness tests.

\section{AdDitional ANALYSES}

Having established clear, robust evidence that bank cost of equity falls with capital, especially equity capital, we now investigate this effect in more detail. We conduct a number of additional tests that better enlighten us on the workings of the documented cost of equity effect of bank capital. First, we consider whether the negative capital-cost of equity relationship is stronger for banks with more binding capital constraints. Second, we explore the differences that might exist in the strength of this relationship across developed countries and developed ones. Third, we analyze the capital-cost of equity relationship for large and small banks, separately.

\section{A. Low vs. High Bank Capitalization}

While the empirical evidence we presented so far points to a negative impact of capital on banks' cost of equity across the bank spectrum, the magnitude of this impact may, nevertheless, depend on the particular bank's level of capitalization. Specifically, investors may give more value to additional capital at less capitalized banks. This is because, at a low capital level, regulatory capital requirements are likely (to be) binding, and the likelihood of banks breaching the regulatory minimum capital level is high. Hence, at a low capitalization level, additional capital lowers equity holders' financial risk more than it would at a high capital level (at which a bank has far more than the minimum capital required). Capital's impact on the cost of equity is therefore expected to be greater at low capitalization levels. To examine this conjecture, we run two separate tests. In the first, we estimate the COE model for two subsamples: one that includes observations where the measure of capital is below its country-year median, and another subsample containing observations whose capital 
measure is above the country-year median. ${ }^{8}$ We then compare the magnitudes of the coefficients' effects on the bank capital measures across the two subsamples. In the second test, we perform a quartile regression estimation to verify whether the COE-bank-capital relationship varies across the four bank capital quartiles.

The results of our first test are reported in panel A of Table 6. While the coefficient estimates for the bank capital measures are consistently negative and highly significant across the table's six columns, the results clearly indicate that bank capital has a much stronger effect on the cost of equity for the subsample of observations with capital below the sample median. For instance, the coefficient estimate on EQUITY in the below-median subsamplecolumn (1) - is more than twice its estimate in the above-median subsample (column (2)). To confirm this result, we perform the difference in coefficients t-test between below-median and above-median subsamples. We rely on the t-statistic, which is equal to the difference between EQUITY coefficients across the two subsamples divided by the square root of the sum of each coefficient's squared standard error. Based on the one-tailed $t$-statistic, the decrease in the cost of equity is statistically higher for low-capitalized banks than for those with higher capital ratios. ${ }^{9}$

The results of the quartile regression estimations are presented in panel B of Table 6 . They suggest that the relationship between bank capital and the cost of equity is nonlinear. For instance, the coefficient estimate for EQUITY in the first quartile is more than threefold its estimate in the second and third quartiles and more than tenfold its estimate in the fourth quartile. The marginal impact of capital on bank cost of equity is thus much stronger for banks operating with low levels of capital than for those with high capitalization. In fact, column (1) of panel B in Table 6 suggests that a one percentage point increase in the equity ratio of a bank operating with very low capital (first quartile) lowers its cost of equity by a significant 79 basis points. This result indicates that, at least at low levels of capital, more stringent capital requirements may not cause a rise in banks' overall funding costs.

\footnotetext{
${ }^{8}$ In other words, in each year, and for each country, we calculate the capital measure's median value and use it to separate observations for that specific year and country into two subsamples.

${ }^{9} \mathrm{We}$ also perform the below-above-median tests of the impact of capital on bank COE by splitting observations in two subsamples based on the median value of the capital measure - EQUITY, TIER1, and TOTCAP - of the full sample. Our results point to a stronger impact of bank capital on the cost of equity in the below-median subsample relative to the above-median subsample.
} 


\section{Table 6. Additional Tests. Panel A: Split using country-year median}

\begin{tabular}{|c|c|c|c|c|c|c|}
\hline VARIABLES & $\begin{array}{c}\text { (1) } \\
\text { COE }\end{array}$ & $\begin{array}{c}(2) \\
C O E\end{array}$ & $\begin{array}{c}(3) \\
C O E\end{array}$ & $\begin{array}{c}(4) \\
C O E\end{array}$ & $\begin{array}{c}(5) \\
C O E\end{array}$ & $\begin{array}{c}\text { (6) } \\
C O E\end{array}$ \\
\hline EQUITY & $\begin{array}{c}-0.291 * * * \\
(-4.867)\end{array}$ & $\begin{array}{c}-0.140 * * * \\
(-6.453)\end{array}$ & & & & \\
\hline TIER1 & & & $\begin{array}{c}-0.173 * * \\
(-2.553)\end{array}$ & $\begin{array}{l}-0.009^{*} \\
(-1.782)\end{array}$ & & \\
\hline TOTCAP & & & & & $\begin{array}{c}-0.115^{* *} \\
(-2.192)\end{array}$ & $\begin{array}{c}-0.012 * * \\
(-2.193)\end{array}$ \\
\hline PROV & $\begin{array}{c}0.015^{* * *} \\
(8.793)\end{array}$ & $\begin{array}{c}0.013 * * * \\
(9.259)\end{array}$ & $\begin{array}{c}0.017 * * * \\
(6.119)\end{array}$ & $\begin{array}{c}0.012 * * * \\
(7.822)\end{array}$ & $\begin{array}{c}0.019 * * * \\
(6.301)\end{array}$ & $\begin{array}{c}0.011^{* * *} * \\
(8.464)\end{array}$ \\
\hline INEFF & $\begin{array}{c}0.072 \\
(0.446)\end{array}$ & $\begin{array}{c}-0.282 * * * \\
(-2.713)\end{array}$ & $\begin{array}{c}-0.084 \\
(-0.425)\end{array}$ & $\begin{array}{c}-0.098 \\
(-0.639)\end{array}$ & $\begin{array}{c}-0.104 \\
(-0.476)\end{array}$ & $\begin{array}{c}-0.031 \\
(-0.207)\end{array}$ \\
\hline ROA & $\begin{array}{c}-1.027 * * * \\
(-5.156)\end{array}$ & $\begin{array}{l}-0.0599 \\
(-0.464)\end{array}$ & $\begin{array}{c}-0.972 * * * \\
(-3.454)\end{array}$ & $\begin{array}{c}-0.665^{* * * *} \\
(-4.876)\end{array}$ & $\begin{array}{c}-1.042 * * * \\
(-3.644)\end{array}$ & $\begin{array}{c}-0.678 * * * \\
(-4.858)\end{array}$ \\
\hline DEP & $\begin{array}{c}0.000 \\
(0.000)\end{array}$ & $\begin{array}{l}-0.008^{*} \\
(-1.740)\end{array}$ & $\begin{array}{c}-0.023 * * * \\
(-2.760)\end{array}$ & $\begin{array}{c}-0.014 * * \\
(-2.154)\end{array}$ & $\begin{array}{c}-0.021 * * \\
(-2.149)\end{array}$ & $\begin{array}{c}-0.016^{* * *} \\
(-2.671)\end{array}$ \\
\hline SIZE & $\begin{array}{c}-0.002 * * * \\
(-3.738)\end{array}$ & $\begin{array}{l}-0.001 * \\
(-1.879)\end{array}$ & $\begin{array}{c}-0.002 * * * \\
(-2.693)\end{array}$ & $\begin{array}{c}0.002 * * * \\
(4.148)\end{array}$ & $\begin{array}{c}-0.001 \\
(-0.930)\end{array}$ & $\begin{array}{c}0.002 * * * \\
(4.114)\end{array}$ \\
\hline LGDPC & $\begin{array}{l}-0.002 * \\
(-1.797)\end{array}$ & $\begin{array}{c}-0.001 \\
(-0.822)\end{array}$ & $\begin{array}{c}-0.002 \\
(-1.142)\end{array}$ & $\begin{array}{c}-0.003 * * \\
(-2.572)\end{array}$ & $\begin{array}{c}-0.001 \\
(-0.872)\end{array}$ & $\begin{array}{c}-0.004 * * * \\
(-3.453)\end{array}$ \\
\hline INFL & $\begin{array}{c}0.556^{* * *} \\
(9.411)\end{array}$ & $\begin{array}{c}0.371 * * * \\
(6.477)\end{array}$ & $\begin{array}{c}0.432 * * * \\
(5.756)\end{array}$ & $\begin{array}{c}0.244 * * * \\
(4.608)\end{array}$ & $\begin{array}{c}0.413 * * * \\
(5.409)\end{array}$ & $\begin{array}{c}0.248^{* * * *} \\
(4.469)\end{array}$ \\
\hline MCAP & $\begin{array}{c}-0.008 * * * \\
(-4.979)\end{array}$ & $\begin{array}{c}-0.011 * * * \\
(-7.356)\end{array}$ & $\begin{array}{c}-0.007 * * * \\
(-3.552)\end{array}$ & $\begin{array}{c}-0.019 * * * \\
(-10.754)\end{array}$ & $\begin{array}{c}-0.010 * * * \\
(-5.638)\end{array}$ & $\begin{array}{c}-0.020 * * * \\
(-10.031)\end{array}$ \\
\hline Constant & $\begin{array}{c}0.152 * * * \\
(9.918)\end{array}$ & $\begin{array}{c}0.137 * * * \\
(9.941)\end{array}$ & $\begin{array}{c}0.171 * * * \\
(9.960)\end{array}$ & $\begin{array}{c}0.139 * * * \\
(7.420)\end{array}$ & $\begin{array}{c}0.275 * * * \\
(5.821)\end{array}$ & $\begin{array}{c}0.385 * * * \\
(29.341)\end{array}$ \\
\hline Observations & 8,308 & 8,468 & 4,346 & 4,652 & 4,325 & 4,429 \\
\hline R-squared & 0.293 & 0.233 & 0.297 & 0.242 & 0.301 & 0.257 \\
\hline Year dummies & Yes & Yes & Yes & Yes & Yes & Yes \\
\hline Sample & $\begin{array}{l}\text { Below } \\
\text { median }\end{array}$ & $\begin{array}{l}\text { Above } \\
\text { median }\end{array}$ & $\begin{array}{l}\text { Below } \\
\text { median }\end{array}$ & $\begin{array}{l}\text { Above } \\
\text { median }\end{array}$ & $\begin{array}{l}\text { Below } \\
\text { median }\end{array}$ & $\begin{array}{l}\text { Above } \\
\text { median }\end{array}$ \\
\hline
\end{tabular}

In this Table, Panel A repeats the same analysis as in Table 2 models 3, 6, and 9 for below-median and above-median subsamples. Columns (1) and (2) report the results for observations whose EQUITY ratio is below and above the country-year medians, respectively. Columns (3) and (4) report the results for observations whose TIER1 ratio is below and above the country-year medians, respectively. Columns (5) and (6) report the results for observations whose TOTCAP ratio is below and above the country-year medians, respectively. Panel B repeats the same analysis as in Table 2 models 3, 6, and 9 for the four quartiles, where columns (1), (5), and (9) report the results for the $1^{\text {st }}$ quartile and columns (4), (8), and (12) report the results for the $4^{\text {th }}$ quartile for the variables EQUITY, TIER1, and TOTCAP, respectively. Panel C repeats the same analysis as in Table 2 models 3, 6, and 9 for developed and emerging markets. Panel D repeats the same analysis as in Table 2 models 3, 6, and 9 for small and large banks where small (large) banks are banks whose SIZE is lower (higher) than the median SIZE for all banks from the same country. The total sample consists of 16,776 observations from 62 countries between 1991 and 2017. Appendix A provides definitions and data sources for all the variables. Beneath each coefficient is the robust $t$-statistic. $*, * *$, and $* * *$ indicate significance at the $10 \%, 5 \%$, and $1 \%$ levels, respectively. 


\begin{tabular}{|c|c|c|c|c|c|c|c|c|c|c|c|c|}
\hline \multicolumn{13}{|c|}{$\begin{array}{l}\text { Table 6. Additional Tests (Continued) } \\
\text { Panel B. Quartile regressions of bank capital on the cost of equity }\end{array}$} \\
\hline & (1) & (2) & (3) & (4) & (5) & (6) & (7) & (8) & (9) & (10) & (11) & (12) \\
\hline VARIABLES & COE & COE & COE & COE & COE & COE & COE & COE & COE & COE & COE & COE \\
\hline EQUITY & $\begin{array}{c}-0.789 * * * \\
(-5.447)\end{array}$ & $\begin{array}{l}-0.232 * \\
(-1.881)\end{array}$ & $\begin{array}{c}-0.245^{* *} \\
(-2.291)\end{array}$ & $\begin{array}{c}-0.077 * * * \\
(-3.193)\end{array}$ & & & & & & & & \\
\hline TIER1 & & & & & $\begin{array}{l}-0.151 \\
(-0.977)\end{array}$ & $\begin{array}{l}-0.048 \\
(-0.280)\end{array}$ & $\begin{array}{c}-0.042 \\
(-0.280)\end{array}$ & $\begin{array}{c}-0.021 * * * \\
(-3.188)\end{array}$ & & & & \\
\hline TOTCAP & & & & & & & & & $\begin{array}{c}-0.081 \\
(-0.371)\end{array}$ & $\begin{array}{l}-0.389 * * \\
(-2.448)\end{array}$ & $\begin{array}{c}-0.086 \\
(-0.719)\end{array}$ & $\begin{array}{r}-0.020 * * * \\
(-2.872)\end{array}$ \\
\hline PROV & $\begin{array}{c}0.022 * * * \\
(8.233)\end{array}$ & $\begin{array}{c}0.011 * * * \\
(5.972)\end{array}$ & $\begin{array}{c}0.010 * * * \\
(5.400)\end{array}$ & $\begin{array}{c}0.011 * * * \\
(7.547)\end{array}$ & $\begin{array}{c}0.021 * * * \\
(4.510)\end{array}$ & $\begin{array}{c}0.019 * * * \\
(6.514)\end{array}$ & $\begin{array}{c}0.009 * * * \\
(4.733)\end{array}$ & $\begin{array}{c}0.009 * * * \\
(5.164)\end{array}$ & $\begin{array}{c}0.025^{* * *} \\
(5.226)\end{array}$ & $\begin{array}{c}0.014 * * * \\
(5.182)\end{array}$ & $\begin{array}{c}0.009 * * * \\
(5.242)\end{array}$ & $\begin{array}{c}0.009 * * * \\
(5.036)\end{array}$ \\
\hline INEFF & $\begin{array}{c}-0.419 \\
(-1.349)\end{array}$ & $\begin{array}{c}0.138 \\
(0.928)\end{array}$ & $\begin{array}{c}-0.094 \\
(-0.542)\end{array}$ & $\begin{array}{c}0.150 \\
(1.088)\end{array}$ & $\begin{array}{c}-0.295 \\
(-0.816)\end{array}$ & $\begin{array}{c}-0.733 * * * \\
(-2.961)\end{array}$ & $\begin{array}{c}-0.178 \\
(-0.863)\end{array}$ & $\begin{array}{c}0.604 * * * \\
(3.060)\end{array}$ & $\begin{array}{c}0.170 \\
(0.498)\end{array}$ & $\begin{array}{c}-0.647 * * * \\
(-2.907)\end{array}$ & $\begin{array}{c}-0.218 \\
(-1.056)\end{array}$ & $\begin{array}{c}0.788 * * * \\
(3.610)\end{array}$ \\
\hline ROA & $\begin{array}{c}-0.779 * * \\
(-2.110)\end{array}$ & $\begin{array}{c}-1.204 * * * \\
(-5.461)\end{array}$ & $\begin{array}{c}-0.933 * * * \\
(-4.350)\end{array}$ & $\begin{array}{c}-0.058 \\
(-0.520)\end{array}$ & $\begin{array}{l}-0.955^{* *} \\
(-2.026)\end{array}$ & $\begin{array}{c}-1.354 * * * \\
(-4.918)\end{array}$ & $\begin{array}{c}-0.983^{* * *} \\
(-4.265)\end{array}$ & $\begin{array}{l}-0.254^{*} \\
(-1.780)\end{array}$ & $\begin{array}{l}-0.862 * \\
(-1.882)\end{array}$ & $\begin{array}{c}-1.578 * * * \\
(-6.688)\end{array}$ & $\begin{array}{c}-0.754 * * * \\
(-4.671)\end{array}$ & $\begin{array}{c}-0.468^{* *} \\
(-2.439)\end{array}$ \\
\hline DEP & $\begin{array}{c}0.024 * * * \\
(3.136)\end{array}$ & $\begin{array}{c}-0.003 \\
(-0.433)\end{array}$ & $\begin{array}{c}-0.032 * * * \\
(-3.185)\end{array}$ & $\begin{array}{c}-0.008 \\
(-1.176)\end{array}$ & $\begin{array}{c}0.022^{*} \\
(1.801)\end{array}$ & $\begin{array}{c}-0.017 \\
(-1.578)\end{array}$ & $\begin{array}{c}-0.041 * * * \\
(-4.207)\end{array}$ & $\begin{array}{c}-0.032 * * * \\
(-3.283)\end{array}$ & $\begin{array}{c}0.010 \\
(0.682)\end{array}$ & $\begin{array}{c}0.007 \\
(0.771)\end{array}$ & $\begin{array}{c}-0.044 * * * \\
(-5.445)\end{array}$ & $\begin{array}{c}-0.035^{* * *} \\
(-3.303)\end{array}$ \\
\hline SIZE & $\begin{array}{c}-0.003 * * * \\
(-4.648)\end{array}$ & $\begin{array}{c}-0.001 * * * \\
(-3.269)\end{array}$ & $\begin{array}{c}-0.001 \\
(-1.206)\end{array}$ & $\begin{array}{c}-0.001 \\
(-1.260)\end{array}$ & $\begin{array}{c}-0.000 \\
(-0.313)\end{array}$ & $\begin{array}{c}-0.002 * * * \\
(-2.828)\end{array}$ & $\begin{array}{c}0.000 \\
(0.756)\end{array}$ & $\begin{array}{c}0.003 * * * \\
(3.960)\end{array}$ & $\begin{array}{c}-0.001 \\
(-0.887)\end{array}$ & $\begin{array}{c}0.000 \\
(0.659)\end{array}$ & $\begin{array}{c}0.001 \\
(1.133)\end{array}$ & $\begin{array}{c}0.004 * * * \\
(5.036)\end{array}$ \\
\hline LGDPC & $\begin{array}{c}-0.001 \\
(-0.377)\end{array}$ & $\begin{array}{c}-0.006^{* * *} \\
(-4.184)\end{array}$ & $\begin{array}{c}0.000 \\
(0.196)\end{array}$ & $\begin{array}{c}0.002 * * \\
(2.016)\end{array}$ & $\begin{array}{c}0.003 \\
(1.285)\end{array}$ & $\begin{array}{c}-0.004 * * \\
(-2.451)\end{array}$ & $\begin{array}{c}-0.001 \\
(-1.050)\end{array}$ & $\begin{array}{c}-0.000 \\
(-0.274)\end{array}$ & $\begin{array}{c}-0.002 \\
(-0.886)\end{array}$ & $\begin{array}{c}-0.003 \\
(-1.407)\end{array}$ & $\begin{array}{l}-0.002 * \\
(-1.913)\end{array}$ & $\begin{array}{c}-0.001 \\
(-0.513)\end{array}$ \\
\hline INFL & $\begin{array}{c}0.404^{* * *} \\
(3.343)\end{array}$ & $\begin{array}{c}0.205 * * \\
(2.330)\end{array}$ & $\begin{array}{c}0.621 * * * \\
(7.749)\end{array}$ & $\begin{array}{c}0.459 * * * \\
(7.821)\end{array}$ & $\begin{array}{c}0.319 * * * \\
(3.251)\end{array}$ & $\begin{array}{c}0.190 * * \\
(2.349)\end{array}$ & $\begin{array}{c}0.377 * * * \\
(4.859)\end{array}$ & $\begin{array}{c}0.327 * * * \\
(3.489)\end{array}$ & $\begin{array}{c}0.200 \\
(1.489)\end{array}$ & $\begin{array}{c}0.393 * * * \\
(4.929)\end{array}$ & $\begin{array}{c}0.376^{* * *} \\
(5.270)\end{array}$ & $\begin{array}{c}0.321 * * * \\
(3.722)\end{array}$ \\
\hline MCAP & $\begin{array}{c}-0.002 \\
(-0.936)\end{array}$ & $\begin{array}{c}-0.017 * * * \\
(-10.167)\end{array}$ & $\begin{array}{c}-0.009 * * * \\
(-3.447)\end{array}$ & $\begin{array}{c}-0.013 * * * \\
(-4.484)\end{array}$ & $\begin{array}{c}-0.013 * * * \\
(-3.770)\end{array}$ & $\begin{array}{c}-0.012 * * * \\
(-4.133)\end{array}$ & $\begin{array}{c}-0.014 * * * \\
(-6.236)\end{array}$ & $\begin{array}{c}-0.017 * * * \\
(-6.044)\end{array}$ & $\begin{array}{c}-0.016^{* * *} \\
(-3.754)\end{array}$ & $\begin{array}{c}-0.014 * * * \\
(-4.080)\end{array}$ & $\begin{array}{c}-0.013 * * * \\
(-7.084)\end{array}$ & $\begin{array}{r}-0.020 * * * \\
(-7.685)\end{array}$ \\
\hline Constant & $\begin{array}{c}0.154 * * * \\
(5.666)\end{array}$ & $\begin{array}{c}0.216^{* * *} \\
(9.646)\end{array}$ & $\begin{array}{c}0.145^{* * *} \\
(6.063)\end{array}$ & $\begin{array}{l}0.051 * \\
(1.736)\end{array}$ & $\begin{array}{c}0.111^{* * *} \\
(4.098)\end{array}$ & $\begin{array}{c}0.161 * * * \\
(6.330)\end{array}$ & $\begin{array}{c}0.194 * * * \\
(7.936)\end{array}$ & $\begin{array}{c}0.124 * * * \\
(5.775)\end{array}$ & $\begin{array}{c}0.271 * * * \\
(2.765)\end{array}$ & $\begin{array}{c}0.221 * * * \\
(7.104)\end{array}$ & $\begin{array}{c}0.184 * * * \\
(7.452)\end{array}$ & $\begin{array}{c}0.095 * * * \\
(4.293)\end{array}$ \\
\hline Observations & 4,193 & 4,203 & 4,210 & 4,170 & 2,312 & 2,272 & 2,234 & 2,180 & 2,234 & 2,257 & 2,171 & 2,092 \\
\hline $\begin{array}{l}\text { R-squared } \\
\text { COMMENTS }\end{array}$ & $\begin{array}{c}0.303 \\
\text { Year } \\
\text { dummy }\end{array}$ & $\begin{array}{c}0.305 \\
\text { Year } \\
\text { dummy }\end{array}$ & $\begin{array}{c}0.284 \\
\text { Year } \\
\text { dummy }\end{array}$ & $\begin{array}{c}0.287 \\
\text { Year } \\
\text { dummy }\end{array}$ & $\begin{array}{c}0.313 \\
\text { Year } \\
\text { dummy }\end{array}$ & $\begin{array}{c}0.356 \\
\text { Year } \\
\text { dummy }\end{array}$ & $\begin{array}{c}0.285 \\
\text { Year } \\
\text { dummy }\end{array}$ & $\begin{array}{c}0.207 \\
\text { Year } \\
\text { dummy }\end{array}$ & $\begin{array}{c}0.348 \\
\text { Year } \\
\text { dummy }\end{array}$ & $\begin{array}{c}0.365 \\
\text { Year } \\
\text { dummy }\end{array}$ & $\begin{array}{c}0.284 \\
\text { Year } \\
\text { dummy }\end{array}$ & $\begin{array}{c}0.230 \\
\text { Year } \\
\text { dummy }\end{array}$ \\
\hline
\end{tabular}


Table 6. Additional Tests (Continued) Panel C: Developed versus emerging countries

\begin{tabular}{|c|c|c|c|c|c|c|}
\hline VARIABLES & $\begin{array}{l}(1) \\
\text { COE } \\
\end{array}$ & $\begin{array}{l}(2) \\
C O E \\
\end{array}$ & $\begin{array}{l}\text { (3) } \\
\text { COE } \\
\end{array}$ & $\begin{array}{l}\text { (4) } \\
\text { COE }\end{array}$ & $\begin{array}{l}\text { (5) } \\
\text { COE }\end{array}$ & $\begin{array}{l}\mathbf{6}) \\
\text { COE }\end{array}$ \\
\hline EQUITY & $\begin{array}{c}-0.153 * * * \\
(-9.462)\end{array}$ & $\begin{array}{c}-0.314 * * * \\
(-6.669)\end{array}$ & & & & \\
\hline TIER1 & & & $\begin{array}{c}-0.030 * * * \\
(-4.859)\end{array}$ & $\begin{array}{c}-0.053 * * \\
(-2.257)\end{array}$ & & \\
\hline TOTCAP & & & & & $\begin{array}{c}-0.027 * * * \\
(-4.264)\end{array}$ & $\begin{array}{c}-0.126 * * \\
(-2.544)\end{array}$ \\
\hline PROV & $\begin{array}{c}0.018 * * * \\
(13.453)\end{array}$ & $\begin{array}{c}0.010 * * * \\
(5.818)\end{array}$ & $\begin{array}{c}0.018 * * * \\
(9.036)\end{array}$ & $\begin{array}{c}0.010^{* * * *} \\
(4.269)\end{array}$ & $\begin{array}{c}0.018^{* * *} \\
(8.891)\end{array}$ & $\begin{array}{c}0.010^{* * *} \\
(3.975)\end{array}$ \\
\hline INEFF & $\begin{array}{c}-0.109 \\
(-1.346)\end{array}$ & $\begin{array}{l}-0.107 \\
(-0.492)\end{array}$ & $\begin{array}{c}-0.248^{* *} \\
(-2.012)\end{array}$ & $\begin{array}{c}0.477 \\
(1.569)\end{array}$ & $\begin{array}{l}-0.239^{*} \\
(-1.863)\end{array}$ & $\begin{array}{c}0.677 * * \\
(2.097)\end{array}$ \\
\hline ROA & $\begin{array}{c}-0.828 * * * \\
(-6.915)\end{array}$ & $\begin{array}{c}-0.027 \\
(-0.140)\end{array}$ & $\begin{array}{c}-1.128 * * * \\
(-7.146)\end{array}$ & $\begin{array}{c}-0.443 \\
(-1.572)\end{array}$ & $\begin{array}{c}-1.141 * * * \\
(-7.094)\end{array}$ & $\begin{array}{c}-0.446 \\
(-1.440)\end{array}$ \\
\hline DEP & $\begin{array}{c}-0.015^{* * *} \\
(-4.197)\end{array}$ & $\begin{array}{c}-0.014 \\
(-1.277)\end{array}$ & $\begin{array}{c}-0.028 * * * \\
(-5.276)\end{array}$ & $\begin{array}{c}0.004 \\
(0.307)\end{array}$ & $\begin{array}{c}-0.029 * * * \\
(-5.247)\end{array}$ & $\begin{array}{c}0.001 \\
(0.026)\end{array}$ \\
\hline SIZE & $\begin{array}{c}-0.001 * * * \\
(-5.140)\end{array}$ & $\begin{array}{l}-0.002 * \\
(-1.937)\end{array}$ & $\begin{array}{c}-0.001 \\
(-0.752)\end{array}$ & $\begin{array}{c}0.002 * * * \\
(2.687)\end{array}$ & $\begin{array}{c}-0.001 \\
(-0.547)\end{array}$ & $\begin{array}{c}0.002^{* *} \\
(2.104)\end{array}$ \\
\hline LGDPC & $\begin{array}{c}0.003 \\
(1.408)\end{array}$ & $\begin{array}{c}0.001 \\
(0.953)\end{array}$ & $\begin{array}{c}0.001 \\
(0.313)\end{array}$ & $\begin{array}{c}0.002 \\
(1.341)\end{array}$ & $\begin{array}{c}-0.001 \\
(-0.272)\end{array}$ & $\begin{array}{c}0.002 \\
(1.616)\end{array}$ \\
\hline INFL & $\begin{array}{l}0.103^{*} \\
(1.901)\end{array}$ & $\begin{array}{c}0.463 * * * \\
(10.594)\end{array}$ & $\begin{array}{c}0.167 * * \\
(2.246)\end{array}$ & $\begin{array}{c}0.378 * * * \\
(7.196)\end{array}$ & $\begin{array}{c}0.171^{* *} \\
(2.219)\end{array}$ & $\begin{array}{c}0.383^{* * *} \\
(7.018)\end{array}$ \\
\hline MCAP & $\begin{array}{c}0.001 \\
(0.834)\end{array}$ & $\begin{array}{c}-0.021 * * * \\
(-10.935)\end{array}$ & $\begin{array}{c}-0.005 * * * \\
(-3.157)\end{array}$ & $\begin{array}{c}-0.025 * * * \\
(-9.650)\end{array}$ & $\begin{array}{c}-0.005 * * * \\
(-3.370)\end{array}$ & $\begin{array}{c}-0.026^{* * *} \\
(-10.156)\end{array}$ \\
\hline Constant & $\begin{array}{c}0.122 * * * \\
(5.653)\end{array}$ & $\begin{array}{c}0.101 * * * \\
(2.884)\end{array}$ & $\begin{array}{c}0.150 * * * \\
(3.262)\end{array}$ & $\begin{array}{c}0.134 * * * \\
(3.096)\end{array}$ & $\begin{array}{c}0.167 * * * \\
(3.610)\end{array}$ & $\begin{array}{c}0.119 * * * \\
(4.517)\end{array}$ \\
\hline Observations & 12,799 & 3,977 & 6,827 & 2,171 & 6,665 & 2,089 \\
\hline R-squared & 0.267 & 0.236 & 0.300 & 0.188 & 0.302 & 0.195 \\
\hline Year dummies & Yes & Yes & Yes & Yes & Yes & Yes \\
\hline Sample & Developed & Emerging & Developed & Emerging & Developed & Emerging \\
\hline
\end{tabular}

Table 6. Additional tests (Concluded) Panel D: Small and large banks

\begin{tabular}{|c|c|c|c|c|c|c|}
\hline VARIABLES & $\begin{array}{l}(1) \\
C O E\end{array}$ & $\begin{array}{l}(2) \\
C O E\end{array}$ & $\begin{array}{l}\text { (3) } \\
\text { COE }\end{array}$ & $\begin{array}{l}\text { (4) } \\
\text { COE }\end{array}$ & $\begin{array}{l}\text { (5) } \\
\text { COE }\end{array}$ & $\begin{array}{l}\text { (6) } \\
\text { COE }\end{array}$ \\
\hline \multicolumn{7}{|l|}{ Group1 } \\
\hline EQUITY & $\begin{array}{c}-0.129 * * * \\
(-5.866)\end{array}$ & $\begin{array}{c}-0.256 * * * \\
(-7.745)\end{array}$ & & & & \\
\hline TIER1 & & & $\begin{array}{c}-0.029 * * * \\
(-3.680)\end{array}$ & $\begin{array}{c}-0.024 * * \\
(-2.025)\end{array}$ & & \\
\hline TOTCAP & & & & & $\begin{array}{c}-0.031 * * * \\
(-4.030)\end{array}$ & $\begin{array}{c}-0.026^{* *} \\
(-2.062)\end{array}$ \\
\hline PROV & $\begin{array}{c}0.015^{* * *} \\
(10.198)\end{array}$ & $\begin{array}{c}0.014 * * * \\
(8.542)\end{array}$ & $\begin{array}{c}0.016^{* * *} \\
(7.893)\end{array}$ & $\begin{array}{c}0.014 * * * \\
(6.209)\end{array}$ & $\begin{array}{c}0.015^{* * *} \\
(7.734)\end{array}$ & $\begin{array}{c}0.014 * * * \\
(5.847)\end{array}$ \\
\hline INEFF & $\begin{array}{l}-0.212^{*} \\
(-1.661)\end{array}$ & $\begin{array}{c}-0.015 \\
(-0.111)\end{array}$ & $\begin{array}{c}-0.139 \\
(-0.675)\end{array}$ & $\begin{array}{c}-0.059 \\
(-0.372)\end{array}$ & $\begin{array}{c}-0.116 \\
(-0.529)\end{array}$ & $\begin{array}{c}-0.034 \\
(-0.211)\end{array}$ \\
\hline ROA & $\begin{array}{c}-0.376^{* * *} \\
(-2.766)\end{array}$ & $\begin{array}{c}-0.727 * * * \\
(-3.947)\end{array}$ & $\begin{array}{c}-0.584 * * * \\
(-3.879)\end{array}$ & $\begin{array}{c}-1.043 * * * \\
(-4.400)\end{array}$ & $\begin{array}{c}-0.653 * * * \\
(-4.181)\end{array}$ & $\begin{array}{c}-1.076^{* * *} \\
(-4.241)\end{array}$ \\
\hline DEP & $\begin{array}{l}0.009^{*} \\
(1.685)\end{array}$ & $\begin{array}{c}-0.018 * * * \\
(-3.494)\end{array}$ & $\begin{array}{c}0.022 * * \\
(2.570)\end{array}$ & $\begin{array}{c}-0.034 * * * \\
(-5.552)\end{array}$ & $\begin{array}{c}0.024 * * * \\
(2.590)\end{array}$ & $\begin{array}{c}-0.034 * * * \\
(-5.487)\end{array}$ \\
\hline SIZE & $\begin{array}{l}-0.001 * * \\
(-2.127)\end{array}$ & $\begin{array}{c}-0.001 * * \\
(-2.458)\end{array}$ & $\begin{array}{l}0.002^{* *} \\
(2.477)\end{array}$ & $\begin{array}{l}0.001^{*} \\
(1.650)\end{array}$ & $\begin{array}{l}0.002^{* *} \\
(2.060)\end{array}$ & $\begin{array}{l}0.001 * \\
(1.792)\end{array}$ \\
\hline Group2 & & & & & & \\
\hline LGDPC & $\begin{array}{c}-0.002 * * \\
(-2.111)\end{array}$ & $\begin{array}{l}-0.001 \\
(-1.222)\end{array}$ & $\begin{array}{c}-0.001 \\
(-0.367)\end{array}$ & $\begin{array}{c}-0.004 * * * \\
(-3.504)\end{array}$ & $\begin{array}{c}-0.001 \\
(-0.491)\end{array}$ & $\begin{array}{c}-0.004 * * * \\
(-3.767)\end{array}$ \\
\hline INFL & $\begin{array}{c}0.489 * * * \\
(8.644)\end{array}$ & $\begin{array}{c}0.422 * * * \\
(7.263)\end{array}$ & $\begin{array}{c}0.367 * * * \\
(4.803)\end{array}$ & $\begin{array}{c}0.288^{* * *} \\
(5.223)\end{array}$ & $\begin{array}{c}0.351 * * * \\
(4.496)\end{array}$ & $\begin{array}{c}0.287 * * * \\
(4.935)\end{array}$ \\
\hline MCAP & $\begin{array}{c}-0.007 * * * \\
(-4.239)\end{array}$ & $\begin{array}{c}-0.011 * * * \\
(-8.379)\end{array}$ & $\begin{array}{c}-0.014 * * * \\
(-5.045)\end{array}$ & $\begin{array}{c}-0.013 * * * \\
(-8.962)\end{array}$ & $\begin{array}{c}-0.019 * * * \\
(-6.198)\end{array}$ & $\begin{array}{c}-0.013 * * * \\
(-8.771)\end{array}$ \\
\hline Constant & $\begin{array}{c}0.132 * * * \\
(9.031)\end{array}$ & $\begin{array}{c}0.164 * * * \\
(11.251)\end{array}$ & $\begin{array}{c}0.165^{* *} \\
(2.384)\end{array}$ & $\begin{array}{c}0.371 * * * \\
(25.033)\end{array}$ & $\begin{array}{c}0.081^{* * * *} \\
(3.826)\end{array}$ & $\begin{array}{c}0.174 * * * \\
(8.808)\end{array}$ \\
\hline Observations & 8,469 & 8,307 & 3,587 & 5,411 & 3,457 & 5,297 \\
\hline R-squared & 0.242 & 0.309 & 0.233 & 0.307 & 0.240 & 0.308 \\
\hline $\begin{array}{l}\text { Year dummies } \\
\text { Sample }\end{array}$ & $\begin{array}{c}\text { Yes } \\
\text { Small banks }\end{array}$ & $\begin{array}{c}\text { Yes } \\
\text { Large banks }\end{array}$ & $\begin{array}{c}\text { Yes } \\
\text { Small banks }\end{array}$ & $\begin{array}{c}\text { Yes } \\
\text { Large banks }\end{array}$ & $\begin{array}{c}\text { Yes } \\
\text { Small banks }\end{array}$ & $\begin{array}{c}\text { Yes } \\
\text { Large banks }\end{array}$ \\
\hline
\end{tabular}




\section{B. Advanced vs. Developing countries}

The graphic analysis we presented in Section 2 suggests that bank capitalization in developing countries has kept pace with that of advanced economies. Yet, investors' valuations of bank capital may differ across the two (country) groups. In particular, at the same capital level, equity investors may deem a bank located in a developing country to be much riskier than a bank located in a developed one. The difference in risk perception may be influenced by the higher quality and stricter enforcement of bank regulations in advanced economies, the greater soundness of the banks' balance sheets, etc. To explore the potentially different cost of equity effect of bank capital for developed and developing countries, we estimate the cost of equity model for two separate subsamples: one that includes developed countries' banks, and another, which includes developing countries' banks. Our estimations' results are presented in panel $\mathrm{C}$ of Table 6 . They suggest that more capital lowers a bank's cost of equity regardless of whether the bank is located in a developed or developing country; the coefficient estimates on the capital measures load negative and significant across the two subsamples. However, the magnitude of this effect is higher for developing countries (columns 2, 4, and 6); the coefficient estimates for EQUITY, TIER1, and TOTCAP are much higher in the sample including banks from developing countries than in the sample of advanced economies' banks. The difference in EQUITY coefficients t-test between developing and developed countries confirms this conclusion. In sum, our estimations point to stronger effect of capital on banks' cost of equity in developing countries.

\section{Small vs. large banks}

In this section, we explore whether there is any difference in the capital-cost of equity relationship between small and large banks. To this end, we split our sample into two groups: small banks (those with total assets below the sample median) and large banks (those with total assets above the sample median). We then run separate regressions for small and large banks. The results, reported in panel D of Table 6 , show that our main conclusions continue to hold for both bank sets. In sum, our results do not seem to be driven by bank size.

\section{Conclusion}

By investigating the empirical relationship between bank capital and the cost of equity, our paper contributes to the debate over the merits and costs of increased bank capital. While some academics and policymakers argue in favor of increasing bank capital requirements, others, especially bankers, point out that such increased capital requirements can only drive up banks' funding costs. The latter fail to realize that additional equity in a bank's capital mix is likely to lower risk and induce a decrease in the cost of equity. This can, in turn, limit any rise in the overall cost, if at all. This standard finance theory prediction represents a major building block for assessing the potential impact of additional equity capital requirements on a bank's funding costs. Yet, to our knowledge, no empirical work has attempted to validate this theoretical prediction.

We bridge this gap in the literature by examining the effect of bank capital on the cost of equity using a sample of banks from 62 countries over a 27-year period (1991-2017). 
Consistent with theory, our results suggest that banks operating with higher equity ratios enjoy a lower cost of equity. Using a variety of bank- and country-level controls, different estimation techniques, and a battery of other robustness tests, we find that the effect of increased capital on banks' cost of equity is consistently negative and statistically and economically significant. In our baseline estimations, we find that a one percentage point increase in a bank's equity-to-assets ratio drives down its cost of equity by 18 basis points. The impact of bank capital on the cost of equity is even larger for low capitalized banks. As we move to the lowest quartile of bank capital in our sample, the effect of a one percentage point increase in a bank's equity-to-assets ratio decreases by 79 basis points.

The findings of this paper should help advance the debate over the benefits of higher capital ratios in the banking industry. In particular, within a Modigliani-Miller framework, our results suggest that higher equity capital requirements should not necessarily lead to hikes in banks' overall funding costs because the cost of equity turns out to be sensitive to banks' equity capital levels. If one also accounts for the likely decrease in banks' borrowing costs in the presence of higher equity capital, then, at worst, the overall funding cost does not rise, and, at best, it decreases. Further research is however needed to analyze the cost of debt and overall cost of funding effect of higher bank capital before a verdict on the implications of more stringent capital requirements for banks' cost of funding, lending and real activity might be pronounced. 


\section{References}

Admati, A.R., DeMarzo, P.M., Hellwig, M.F., Pfleiderer, P., 2013. Fallacies, Irrelevant Facts, and Myths in the Discussion of Capital Regulation: Why Bank Equity is Not Socially Expensive. Discussion Paper Series of the Max Planck Institute for Research on Collective Goods 2013_23, Max Planck Institute for Research on Collective Goods.

Admati, A.R., Hellwig, M.F., 2013. The bankers' new clothes: What's wrong with banking and what to do about it. Princeton University Press. (Excerpts and links available at http://bankersnewclothes.com/.

Anderson, T. W., 1951. Estimating linear restrictions on regression coefficients for multivariate normal distributions. Annals of Mathematical Statistics 22, 327-351.

Baker, M.P. Wurgler, J., 2013. Do strict capital requirements raise the cost of capital? Banking regulation and the low risk anomaly. NBER Working paper.

Bekaert, G., Harvey, C., 2000. Foreign speculations and emerging equity markets. Journal of Finance 55, 565-613.

Belkhir, M., 2013. Do subordinated debtholders discipline bank risk-taking: Evidence from risk management decisions. Journal of Financial Stability 9, 705-719.

Belkhir, M., Saad, M., Samet, A. 2019. Stock extreme illiquidity and the cost of capital. Journal of Banking and Finance, forthcoming.

Beltratti, A., Stulz, R.M., 2012. The credit crisis around the globe: Why did some banks perform better? Journal of Financial Economics 105, 1-17.

Berger, A.B., El Ghoul, S., Guedhami, O., Roman .R.A., 2018. Competition and Banks' Cost of Equity Capital: Evidence from Relatively Exogenous Differences in Regulation. Working paper.

Berger, A.N., Bowman, C.H.S., 2013. How does capital affect bank performance during financial crises? Journal of Financial Economics 109, 146-176.

Botosan, C.A., Plumlee, M.A., Wen, H., 2011. The Relation between Expected Returns, Realized Returns, and Firm Risk Characteristics. Contemporary Accounting Research 28, 1085-1122.

Chen, K.C.W., Chen, Z., Wei, K.C.J., 2011. Agency costs of free cash flow and the effect of shareholder rights on the implied cost of equity capital. Journal of Financial and Quantitative Analysis 46, 171-207.

Chen, K.C.W., Chen, Z.-H., Wei, K.C.J., 2009. Legal protection of investors, corporate governance, and the cost of equity capital. Journal of Corporate Finance 15, 279-289.

Chen, Z., Li, O.Z., Zou, H. 2016. Directors' and Officers' Liability Insurance and the Cost of Equity. Journal of Accounting and Economics 61, 100-120.

Claus, J., Thomas, J., 2001. Equity premia as low as three percent? Evidence from analysts' earnings forecasts for domestic and international stock markets. Journal of Finance $56,1629-1666$. 
Cragg, J.G., Donald, S.G., 1993. Testing identifiability and specification in instrumental variable models. Econometric Theory 9, 222 - 240.

Del Negro, M., Giannone, D., Giannoni, M.P., Tambalotti, A., 2018. Global trends in interest rates. NBER Working Paper No. 25039.

Demirguc-Kunt, A., Detragiache, E., Meerouche, O., 2013. Bank Capital: Lessons from the Financial Crisis. Journal of Money, Credit and Banking 45, 1147-1164.

Demsetz, R.S., and Strahan, P.E., 1997. Diversification, Size, and Risk at Bank Holding Companies. Journal of Money, Credit and Banking 29, 300-313.

Deng, S., Elyasiani, E., Mao, C.X., 2007. Diversification and the cost of debt of bank holding companies. Journal of Banking and Finance 31, 2453-2473.

Dhaliwal, D., Heitzman, S., Li, O., 2006. Taxes, leverage, and the cost of equity capital. Journal of Accounting Research 44, 691-723.

Easton, P., 2004. PE ratios, PEG ratios, and estimating the implied expected rate of return on equity capital. Accounting Review 79, 73-95.

Elliott, D.J., 2013. Higher bank capital requirements would come at a price. Working paper.

Fama, E.F., MacBeth, J.D., 1973. Risk, return and equilibrium: Empirical tests. Journal of Political Economy 81, 607-636.

Frankel, R., Lee, C. 1998. Accounting valuation, market expectation, and cross-sectional stock returns. Journal of Accounting and Economics 25, 283-319.

Gebhardt, W., Lee, C., Swaminathan, B., 2001. Towards an implied cost of capital. Journal of Accounting Research 39, 135-176.

Hail, L., Leuz, C., 2006. International differences in cost of equity capital: do legal institutions and securities regulation matter? Journal of Accounting Research 44, 485-531.

Hail, L., Leuz, C., 2009 Cost of capital effects and changes in growth expectations around U.S. cross-listings. Journal of Financial Economics 93, 428-454.

Jayaraman, S., Milbourn, T.T., 2012. The role of stock liquidity in executive compensation. The Accounting Review 87, 537-563.

Kashyap, A.K., Stein, J.C., Hanson, S., 2010. An analysis of the impact of 'substantially heightened' capital requirements on large financial institutions. Working paper.

Li, Y., Ng, D., Swaminathan, B., 2013. Predicting market returns using aggregate implied cost of capital. Journal of Financial Economics 110, 419-436.

Modigliani, F., Miller, M.H., 1958. The cost of capital, corporation finance and the theory of investment. American Economic Review, 261-297.

Newey, W.K., West, K.D., 1987. A simple, positive semi-definite, heteroskedasticity and autocorrelation consistent covariance matrix. Econometrica 55, 703-08.

Ohlson, J., Juettner-Nauroth, B., 2005. Expected EPS and EPS growth as determinants of value. Review of Accounting Studies 10, 349-365. 
Pastor, L., Sinha, M., Swaminathan, B., 2008. Estimating the inter-temporal risk- return tradeoff using the implied cost of capital. Journal of Finance 63, 2859- 2897.

Saad, M., Samet, A., 2017. Liquidity and the implied cost of equity capital. Journal of International Financial Markets, Institutions, and Money 51, 15-38.

Sanderson, E., Windmeijer, F., 2016. A weak instrument F-test in linear IV models with multiple endogenous variables. Journal of Econometrics 190, 212-221. 


\section{Appendix A: Variables, definitions, and sources}

\begin{tabular}{|c|c|c|}
\hline Variable & Definition & Source \\
\hline \multicolumn{3}{|c|}{ Panel A. Implied Cost of Equity } \\
\hline $\mathrm{R}_{\mathrm{CT}}$ & Implied cost of equity estimated using the Claus and Thomas (2001) model. & $\begin{array}{l}\text { Authors' calculation based } \\
\text { on } \mathrm{I} / \mathrm{B} / \mathrm{E} / \mathrm{S} \text { and DataStream. }\end{array}$ \\
\hline $\mathrm{R}_{\mathrm{GLS}}$ & Implied cost of equity estimated using the Gebhardt et al. (2001) model. & As above \\
\hline $\mathrm{R}_{\mathrm{OJ}}$ & $\begin{array}{l}\text { Implied cost of equity estimated using the Ohlson and Juttner-Nauroth } \\
\text { (2005) model. }\end{array}$ & As above \\
\hline $\mathrm{R}_{\mathrm{ES}}$ & Implied cost of equity estimated using the Easton (2004) model. & As above \\
\hline $\mathrm{COE}$ & Equally weighted average of $\mathrm{R}_{\mathrm{ES}}, \mathrm{R}_{\mathrm{OJ}}, \mathrm{R}_{\mathrm{CT}}$, and $\mathrm{R}_{\mathrm{GLS}}$ & As above \\
\hline RES_GLS & Equally weighted average of $\mathrm{R}_{\mathrm{ES}}$ and $\mathrm{R}_{\mathrm{GLS}}$ & As above \\
\hline RPCA & Principal component of $\mathrm{R}_{\mathrm{ES}}, \mathrm{R}_{\mathrm{OJ}}, \mathrm{R}_{\mathrm{CT}}$, and $\mathrm{R}_{\mathrm{GLS}}$ & As above \\
\hline RPM & $\begin{array}{l}\text { Risk premium, which is equal to cost of equity measured by COE minus } \\
\text { the } 10 \text { year U.S. Treasury bond yield. }\end{array}$ & As above \\
\hline \multicolumn{3}{|c|}{ Panel B. Capital ratio variables } \\
\hline EQUITY & The lagged equity-to-assets ratio. & $\begin{array}{l}\text { Authors' calculation based on } \\
\text { Bloomberg, DataStream, and } \\
\text { Reuters. }\end{array}$ \\
\hline TIER1 & The lagged (Tier 1 /Risk weighted assets) ratio. & As above \\
\hline TOTCAP & The lagged ((Tier 1+Tier 2)/Risk weighted assets) ratio. & As above \\
\hline \multicolumn{3}{|c|}{ Panel C. Bank-level control variables } \\
\hline PROV & The lagged loan loss provision to total loans ratio. & $\begin{array}{l}\text { Authors' calculation based } \\
\text { on Bloomberg, DataStream, } \\
\text { and Reuters. }\end{array}$ \\
\hline INEFF & The lagged (Salaries and benefits/total assets) ratio. & As above \\
\hline ROA & The lagged return on assets ratio. & As above \\
\hline DEP & The lagged (Total deposits/Total assets) ratio. & As above \\
\hline SIZE & The lagged natural logarithm of the bank's total assets in US dollar & As above \\
\hline RSTD & The lagged standard deviation of daily returns over one year period & As above \\
\hline BETA & $\begin{array}{l}\text { The lagged beta estimated as the covariance between the firm returns and } \\
\text { the market return relative to the variance of the market returns. }\end{array}$ & As above \\
\hline MTOV & The lagged one-year turnover volume. & As above \\
\hline NPL & The lagged non-performing loans to total loans ratio & As above \\
\hline BTM & The book-to-market ratio. & As above \\
\hline \multicolumn{3}{|c|}{ Panel D. Country-level control variables } \\
\hline LNGDP & The lagged logarithm of GDP per capita. & $\begin{array}{l}\text { International Financial } \\
\text { Statistics and World } \\
\text { Development Indicators }\end{array}$ \\
\hline INFL & $\begin{array}{l}\text { The lagged inflation measured as the annualized yearly median of a } \\
\text { country-specific one-year-ahead realized monthly inflation rate. }\end{array}$ & As above \\
\hline MCAP & $\begin{array}{l}\text { The lagged (Total stock market capitalization/GDP) ratio at the country } \\
\text { level. }\end{array}$ & As above \\
\hline
\end{tabular}




\section{Appendix B: Cost of equity models}

\section{Claus and Thomas (2001) model}

This model assumes clean surplus accounting, allowing the current share price to be expressed in terms of the cost of equity, current book value, forecasted abnormal earnings,

and perpetual abnormal earnings growth. Forecasted abnormal earnings (ae) is given by forecasted earnings minus a charge for the cost of equity. The explicit forecast horizon is set at five years, beyond which forecasted residual earnings grow at the expected inflation rate. The valuation equation is given by

$$
P_{t}=B_{t}+\sum_{\tau=1}^{5} \frac{a e_{t+\tau}}{\left(1+r_{C T}\right)^{\tau}}+\frac{a e_{t+5}\left(1+i_{t}\right)}{\left(r_{C T}-i_{t}\right)\left(1+r_{C T}\right)^{5}}
$$

where $P_{t}$ represents stock price at time $\mathrm{t}$, and $i_{t}$ is defined as the long-term abnormal earnings growth rate calculated using the annualized yearly median of a country-specific oneyear-ahead realized monthly inflation rate. $B_{t}$ is the current book value per share (at the beginning of year $t$ ), $a e_{t+\tau}=F E P S_{t+\tau}-r_{C T} . B_{t+\tau-1}, B_{t+\tau}$ is the forecasted book value per share for year $t+\tau-$ measured using the clean surplus relationship (i.e., $\left.B_{t+\tau-1}+F E P S_{t+\tau}\left(1-r_{t+\tau}\right)\right)-$ and $r_{C T}$ is the cost of equity capital. Eq. (B.1) is solved numerically for $r_{C T \text {. }}$

\section{Gebhardt et al. (2001) model}

This model also assumes clean surplus accounting, where the share price is expressed in terms of the cost of equity, the current book value, and forecasted ROE and book value. The explicit forecast horizon is set at three years, beyond which forecasted ROE decays to a target ROE by the twelfth year and remains constant afterward. The model equation is given by

$$
P_{t}=B_{t}+\sum_{\tau=1}^{11} \frac{F R O E_{t+\tau}-r_{G L S}}{\left(1+r_{G L S}\right)^{\tau}} B_{t+\tau-1}+\frac{F R O E_{t+12}-r_{G L S}}{r_{G L S}\left(1+r_{G L S}\right)^{11}} B_{t+11}
$$


where $P_{t}$ and $B_{t}$ are refined, as in the previous models; FROE $E_{t+\tau}$ is the forecasted ROE for year $t+\tau$; and $r_{G L S}$ is the cost of equity capital. Eq. (B.2) is solved numerically for $r_{G L S}$.

\section{Ohlson and Juettner-Nauroth (2005) model}

This model is an extension of the Gordon constant growth model. It allows share price to be expressed in terms of the cost of equity, the one-year-ahead earnings forecast, and the near-term and perpetual growth forecasts. The explicit forecast horizon is set at one year, after which forecast earnings grow at near-term rates, which decay into a perpetual rate. Near-term earnings growth is the average of i) the growth rates of forecasted earnings per share (FEPS) from year $t+1$ to year $t+2$, and ii) the I/B/E/S long-term growth forecast (LTG). The perpetual growth rate is the expected inflation rate. The valuation equation is given by

$$
P_{t}=\frac{F E P S_{t+1}\left(g_{t}-i_{t}+r_{O J N} \cdot d_{t+1}\right)}{r_{O J N}\left(r_{O J N}-i_{t}\right)}
$$

where $P_{t}$ is the stock price recorded 10 months after the fiscal year-end; $F E P S_{t+\tau}$

represents the forecasted earnings for year $t+\tau, g_{t}=0.5\left(\frac{F E P S_{t+2}}{F E P S_{t+1}}-1+L T G_{t}\right) ; d_{t}$ is the expected dividend payout at time $t$, estimated using the average dividend payout over the last three years, $; i_{t}$ is the forecasted earnings growth at time 3 , measured as the realized inflation in year $t+1$; and $r_{O J N}$ is the cost of equity capital. Eq. (B.3) is solved analytically (i.e., the solution is a closed-form expression) for $r_{C T}$. The model requires that $F E P S_{t+2}>0$ and $F E P S_{t+1}>0$ to yield a positive root.

\section{Easton (2004) model}

This model is a generalization of the Price-Earnings-Growth (PEG) model. It expresses current share price in terms of the cost of equity, the expected dividend payout, and one- and two-year-ahead earnings forecasts. The explicit forecast horizon is set at two years, after 
which forecasted abnormal earnings grow in perpetuity at a constant rate. The expression of Easton's (2004) valuation model is given by

$$
P_{t}=\frac{F E P S_{t+2}-F E P S_{t+1}\left(1-r_{E a s t o n} \cdot d_{t+1}\right)}{r_{E^{2} t o n}{ }^{2}}
$$

where $P_{t}, F E P S_{t+\tau}$ and $d_{t}$ are defined as they were in the previous model. Knowing all the parameters, Eq. (B.4) is solved numerically for $r_{\text {Easton. }}$. The model requires that $F E P S_{t+2}>0$ and $F E P S_{t+1}>0$ to yield a positive root. 